QUARTERLY TECHNICAL PROGRESS REPORT NO. 24

FOR PERIOD

JULY 1, 1994 THROUGH SEPTEMBER 30, 1994

DOE CONTRACT \#DE-AC22-88PC88881

ICF KAISER ENGINEERS JOB NO. 88107

We have no objection from a patent

standpoint to the publication or

dissemination of this material.

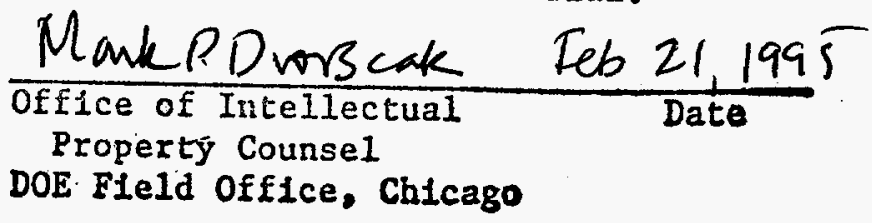

"This report was prepared as an account of work performed by ICF Kaiser Engineers under sponsorship of the United States Government. Neither the United States nor the United States Department of Energy, ICF Kaiser Engineers, its subcontractors, nor any of their employees, makes any warranty, express or implied, or assumes any legal liability or responsibility for the accuracy, completeness, or usefulness of any information, apparatus, product, or process disclosed, or represents that its use would not infringe privately-owned rights. Reference herein to any specific commercial product, process, or service by trade name, mark, manufacturer, or otherwise, does not necessarily constitute or imply its endorsement, recommendation, or favoring by the United States Government or any agency thereof. The views and opinions of authors expressed herein do not necessarily state or reflect those of the United States Government or any agency thereof." 


\section{DISCLAIMER}

Portions of this document may be illegible in electronic image products. Images are produced from the best available original document. 
1.0 INTRODUCTION

1.1 Scope of this Document

1.2 Overall Project Scope

1.3 Work Executed at Different Locations

2.0 TASK 2 PRELIMINARY CONCEPTUAL DESIGN

2.1 Overview and Scope

2.2 Review of Work Completed This Quarter

$\begin{array}{llll}3.0 & \text { TASK } 3 & \text { CRITICAL AREA DETERMINATION } & 5\end{array}$

3.1 Overview and Scope

3.2 Review of Work Completed This Quarter

$4.0 \quad$ TASK 4 TEST PLAN FORMULATION 6

4.1 Overview and Scope 6

4.2 Review of Work Completed This Quarter 7

$\begin{array}{llll}5.0 & \text { TASK } 5 & \text { BENCH-SCALE PROCESS TESTING } & 8\end{array}$

5.1 Overview and Scope 8

5.2 Review of Work Completed This Quarter 8

6.0 COMPONENT AND UNIT OPERATIONS DEVELOPMENT 9

6.1 Overview and Scope 9

6.2 Review of Work Completed this Quarter 9

$\begin{array}{lll}7.0 & \text { EVALUATION OF BENCH-SCALE AND COMPONENT TEST RESULTS } & 10\end{array}$

$\begin{array}{lll}7.1 & \text { Overview and Scope } & 10\end{array}$

7.2 Work Complete this Quarter 10

8.0 REVISED CONCEPTUAL DESIGN OF SEMI-WORKS PLANT 11

8.1 Overview and Scope 11

8.2 Review of Work Completed this Quarter 11

9.0 POC MODULE DESIGN 12

9.1 Overview and Scope 12

9.2 Review of Work Completed this Quarter 12

$\begin{array}{lll}10.0 & \text { POC MODULE FABRICATION } & 13\end{array}$

10.1 Overview and Scope 13

10.2 Review of Work Completed this Quarter 13 
11.1 Overview and Scope

11.2 Review of Work Completed this Quarter

12.0 POC TEST PLAN FORMULATION

12.1 Overview and Scope

12.2 Review of Work Completed this Quarter

13.0 POC OPERATION

13.1 Overview and Scope

13.2 Review of Work Completed this Quarter

14.0 POC OPERATIONS ANALYSIS

14.1 Overview and Scope

14.2 Review of Work Completed this Quarter

15.0 FINAL SEMI-WORKS CONCEPTUAL DESIGN 41

15.1 Overview and Scope

15.2 Review of Work Completed This Quarter

16.0 POC MODULE REMOVAL

16.1 Overview and Scope

16.2 Review of Work Complete This Quarter

APPENDIX A - Equipment List for Semi-Works Plant Detailed Capital Cost Estimate 


\section{LIST OF FIGURES}

FIGURE

1.1

14.1

14.2

14.3

14.4

14.5

14.6

14.7

14.8

14.9

14.10

14.11

14.12

IITLE

Project Organization Chart

Heavy-media Cyclone Btu Recovery, Ash Rejection, and Pyritic Sulfur Rejection for the Long-Duration Testing of the Pittsburgh No. 8 Coal

Heavy-media Cyclone Btu Recovery, Ash Rejection, and Pyritic Sulfur Rejection for the Long-Duration Testing of the Upper Freeport Coal

Heavy-media Cyclone Btu Recovery, Ash Rejection, and Pyritic Sulfur Rejection for the Long-Duration Testing of the Illinois No. 6 Coal

Water-only Cyclone Btu Recovery, Ash Rejection, and Pyritic Sulfur Rejection for the Long-duration Testing of the Pittsburgh No. 8 Coal

Water-only Cyclone Btu Recovery, Ash Rejection, and Pyritic Sulfur Rejection for the Long-duration Testing of the Upper Freeport Coal

Water-onty Cyclone Btu Recovery, Ash Rejection, and Pyritic Sulfur Rejection for the Long-duration Testing of the Illinois No. 6 Coa 7

Advanced Column Flotation Btu Recovery, Ash Rejection, and Pyritic Sulfur Rejection for the Long-Duration Testing of the Pittsburgh No. 8 Coal

Advanced Column Flotation Btu Recovery, Ash Rejection, and Pyritic Sulfur Rejection for the Long-Duration Testing of the Upper Freeport Coal

Advanced Column Flotation Btu Recovery, Ash Rejection, and Pyritic Sulfur Rejection for the Long-Duration Testing of the Illinois No. 6 Coal

Overall POC Circuit Btu Recovery, Ash Rejection, and Pyritic Sulfur Rejection for the Long Duration Testing of the Pittsburgh No. 8 Coal

Overall POC Circuit Btu Recovery, Ash Rejection, and Pyritic Sulfur Rejection for the Long Duration Testing of the Upper Freeport Coal

Overall POC Circuit Btu Recovery, Ash Rejection, and Pyritic Sulfur Rejection for the Long Duration Testing of the Illinois No. 6 Coal 


\section{LIST OF TABLES}

\section{$\underline{\text { TABLE }}$}

1.1

14.1

14.2

14.3

14.4

14.5

14.6

14.7

14.8

14.9

14.10

14.11

14.12

14.13

\section{IITLE}

Task and the Responsible Team Member

Test Conditions Examined During the 24-hour Demonstration

Average 24-hour Demonstration Test Results for the HMC Circuit

Average 24-hour Demonstration Test Results for the WOC Circuit

Average 24-hour Demonstration Test Results for the Column Circuit

Average 24-hour Demonstration Test Results for the Overall Plant Circuit

Summation of 24-hour Demonstration Results

Column Design Criteria

Reagent Consumptions - Pittsburgh No. 8

Reagent Consumptions - Upper Freeport

Reagent Consumptions - Illinois No. 6

Unit Operation Changes

Instrument Changes

Plant Availability 
A study conducted by Pittsburgh Energy Technology Center of sulfur emissions from about 1,300 United States coal-fired utility boilers indicated that half of the emissions were the result of burning coals having greater than 1.2 pounds of $\mathrm{SO}_{2}$ per million BTU. This was mainly attributed to the high pyritic sulfur content of the boiler fuel. A significant reduction in $\mathrm{SO}_{2}$ emissions could be accomplished by removing the pyrite from the coals by advanced physical fine coal cleaning.

An engineering development project was prepared to build upon the basic research effort conducted under a solicitation for research into Fine Coal Surface Control. The engineering development project is intended to use general plant design knowledge and conceptualize a plant to utilize advanced froth flotation technology to process coal and produce a product having maximum practical pyritic sulfur reduction consistent with maximum practical BTU recovery.

\subsection{Scope of this Document}

The Department of Energy (DOE) awarded a contract entitled "Engineering Development of Advanced Physical Fine Coal Cleaning Technology - Froth Flotation", to ICF Kaiser Engineers with the following team members, Ohio Coal Development Office, Babcock and Wilcox, Consolidation Coal Company, Eimco Process Equipment Company, Illinois State Geological Survey, Virginia Polytechnic Institute and State University, Process Technology, Inc. The organizational chart for this project is presented in Figure 1.1 .

This document a quarterly report prepared in accordance with the project reporting requirements covering the period from October 1 , 1993 to December 31,1993 . This report provides a summary of the technical work undertaken during this period, highlighting the major results. A brief description of the work done prior to this quarter is provided in this report under the task headings.

\subsection{Overall Project Scope}

The overall project scope of the engineering development project is to conceptually develop a commercial flowsheet to maximize pyritic sulfur reduction at practical energy recovery values. This is being accomplished by utilizing the basic research data on the surface properties of coal, mineral matter and pyrite obtained from the Coal Surface Control for Advanced Fine Coal Flotation Project, to develop this conceptual flowsheet. The conceptual flowsheet must be examined to identify critical areas that need additional design data. This data will then be developed using batch and semicontinuous bench scale testing. In addition to actual bench scale testing, other unit operations from other industries processing fine material will be reviewed for potential application and incorporated into the design if appropriate.

The conceptual flowsheet will be revised based on the results of the bench scale testing and areas will be identified that need further larger scale design data verification, to prove out the design. The 


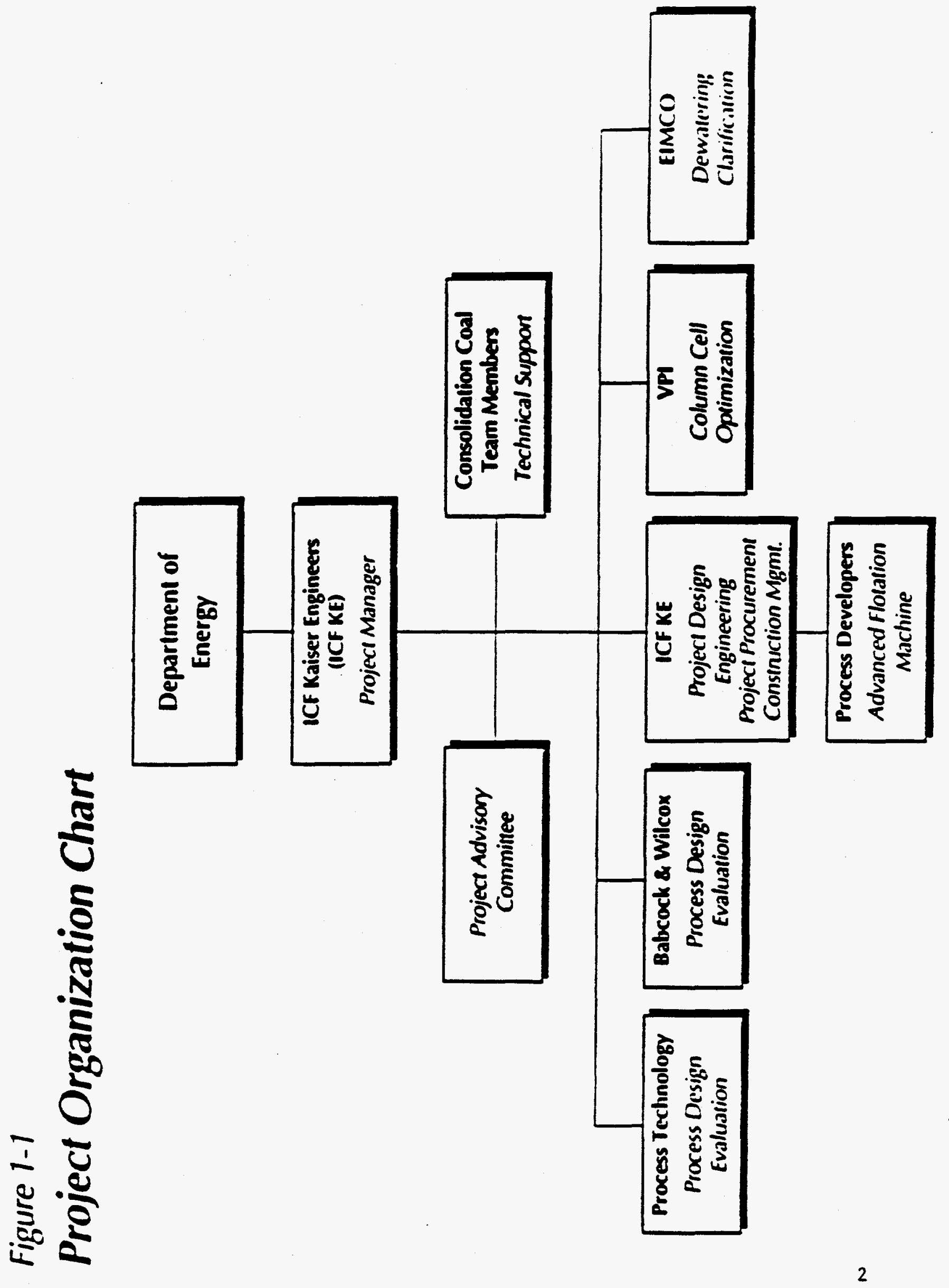


proof-of-concept will be accomplished by designing, constructing, operating and testing a 2-3 ton per hour proof-of-concept plant. This plant will be designed for continuous operation and will include two consecutive 5 days, 24 hour per day runs on each of the three test coals to demonstrate process performance on a commercial basis.

The data from the basic research on coal surfaces, bench scale testing and proof-of-concept scale testing will be utilized to design a final conceptual flowsheet.

The economics of the flowsheet will be determined to enable industry to assess the feasibility of incorporating the advanced fine coal cleaning technology into the production of clean coal for generating electricity. This concept should provide an ability to reduce sulfur oxide emissions more economically than FGD systems when compared on a dollar per ton of sulfur removed basis.

1.3 Work Executed at Different Locations

The project team consists of research and engineering groups at ICF Kaiser Engineers, Babcock and Wilcox, Consolidation Coal Company, Eimco Process Equipment Company, Illinois State Geological Survey, Virginia Polytechnic Institute and State University, Process Technology, Inc. and Michigan Technological University Institute of Materials Processing with ICF Kaiser Engineers as the prime contractor with DOE. The work being conducted by different organizations is based upon their area of expertise and this has been incorporated into the project Work Plan. The work undertaken by the different organizations is identified in Table 1.1. This report is prepared in an integrated manner combining work done by each organization by task. This is considered to be a more effective way of presenting the technical data developed by each organization.

Table 1.1

Task and the Responsible Team Member

Task 1

Task 2

Task 3

Task 4

Task 5

Task 6

Task 7

Task 8

Task 9

Task 10

Task 11

Task 12

Task 13

Task 14

Task 15

Task 16
Project Planning

Preliminary Conceptual Design

Determination of Critical Areas

Test Plan Formulation

Bench Scale Testing

Component Development

Analysis of Test Results

Revised Conceptual Design

POC Module Design

POC Procurement and Fabrication

POC Installation and Startup

POC Test Plan Formulation

POC Testing and Operation

Analysis of POC Test Results

Final Conceptual Design

POC Module Removal
ICF KE

ICF KE, B\&W, EIMCO, TSG, TAC

ICF KE, B\&W, EIMCO, TSG, TAC

ICF KE, B\&W, EIMCO, TSG

ICF KE, B\&W, EIMCO, PTI, TSG, TAC

VPI, TSG

ICF KE, B\&W, EIMCO, VPI, TSG

ICF KE

ICF KE, B\&W, EIMCO, TSG, TAC

ICF KE

ICF KE, B\&W, EIMCO, TSG

ICF KE, B\&W, EIMCO, TSG, TAC

ICF KE, B\&W, EIMCO, TSG

ICF KE, B\&W, EIMCO, TSG

ICF KE, B\&W, EIMCO, TSG

ICF KE 


\subsection{TASK 2 PRELIMINARY CONCEPTUAL DESIGN}

\subsection{Overview and Scope}

The previous completion of this task resulted in the preliminary conceptual design of a 20TPH semi-works advanced froth flotation facility. The non-site-specific plant was designed using the best available information and technology to achieve continuous, steady-state process operation with $90 \%$ availability. The process plant is a fully instrumented, integrated, stand-alone facility. A greenfield site was assumed for the plant.

Throughout the project, the work was organized along a task/sub-task basis with each sub-task logically assigned to provide necessary information for the next sub-task, ultimately resulting in completion of the conceptual design. For Task 2, the first sub-task determined the design criteria needed to meet or exceed the advanced froth flotation process specifications. At completion, work under this sub-task provided information to design the flowsheet of the process, and provided an energy and material balance of all process streams. A list of all major process equipment was prepared and used as a basis for a factored estimate for the capital, operating and maintenance costs of the semi-works process and plant.

ICF Kaiser Engineers, assisted by the project sub-contractors and Technical Support Group, was responsible for the performance and completion of this task. This conceptual design is the basis for Tasks 3, 4, 5, and 6 and will be revised in Task 8 for use as a basis for the 2-3TPH POC module design in Task 9.

\subsection{Review of Work Completed This Quarter}

On August 15, 1989, DOE approved Task 1.2 as submitted. With this as a basis, ICF KE and the team members proceeded with the remainder of the project. No additional work was planned nor completed during this quarter. 


\subsection{Overview and Scope}

Work performed during the conceptual design of Task 2 identified areas where uncertainties exist in the design of the unit operations for the advanced froth flotation process. Some of these problem areas could not be solved based on currently available information or technology. The objective of this task was to determine those critical areas where more information would be necessary and outline the work needed to obtain the design information.

A design deficiency list was generated, and the project team determined the parameters needed for final design of the unit operation - either by further engineering analysis or by experimental data obtained from bench-scale tests. Other solids processing industries, such as phosphate and clay beneficiation, were examined to assess the means by which they effectively process ultra fine particles.

Each identified design deficiency was then ranked according to its relative importance to the successful continuous operation of the advanced froth flotation process. Both a technical and economic analyses of the consequences of not being able to gather the required design information for each deficiency was evaluated.

ICF Kaiser Engineers, Consolidation Coal and the other members of the Technical Support Team (B\&W, VPI and EIMCO) have contributed to this task. The process deficiencies identified in this task will be addressed in Tasks 4, 5, and 6 through additiona 7 engineering computation and analysis and experimental techniques.

\subsection{Review of Work Completed This Quarter}

The final report of this task has been submitted to DOE. No additional work was planned nor completed during this quarter. 


\subsection{TASK 4 TEST PLAN FORMULATION}

\subsection{Overview and Scope}

Work completed in this task produced the criteria for additional engineering analysis, computation and detailed experimental benchscale testing for areas of uncertainty identified in Task 3 . The engineering analysis, computation, bench-scale testing and component development was formulated to produce necessary design information to define a commercially operating system.

In order to produce the required information by means of bench-scale testing and component development, a uniform coal sample was procured. After agreement with DOE, a selected sample of coal from those previously listed was secured.

The test plan was developed in two parts. The first part listed procedures for engineering and computational analyses of those deficiencies previously identified that could be solved without bench scale testing. Likewise, the second part prepared procedures for bench-scale testing and component development for those deficiencies previously identified in Task 3 .

The first part, engineering analysis and computation, provided for means of employing presently know theory from other industries to address deficiencies. This included examinations of literature and contacting proven experts and operating personnel in fields related to this deficiency. From the information gathered, engineering calculations will be utilized to resolve this type of deficiency.

The second part, bench-scale testing and component development, became necessary when the part one information was unavailable or when the theory had never been commercially applied. Justification for the test work was provided to show that technical data and process needs could only be obtained by test work and that the test work results would produce necessary information to define a commercially operating system.

The test work planned was based upon non-continuous and/or semicontinuous bench-scale units of general laboratory design and would include only those unit operations identified as deficiencies in Task 3.

The detailed, quantified tests addressed obtaining data necessary for solving problems uncovered in the deficiency review. Each identified deficiency had a plan developed to address the reason for the testing, the means for the test matrix to obtain results and the expected results. Each test plan established procedures, adhering as much as possible, to known and industry-acceptable procedures for sampling and data collection. Raw data collection would be reduced to minimize expenses and to better be able to compare results and obtain meaningful information, especially scale-up factors. 
The Development Test Plan for both parts one and two contained schedules, manpower requirements, and resources necessary to obtain information to define a commercially available system.

The plan for use of the team members was developed to comply with the results of the DOE uniform coal sample procurement and storage procedures. The quantity of coal necessary for each testing program was calculated. A sample of all three of the referenced coals was to be obtained, preferably from the same source as the Surface Control contractor. This coal would be stored and handled as outlined in the coal procurement and storage plan. These procedures, when properly followed, should minimize physical and chemical changes to the raw coal.

\subsection{Review of Work Completed This Quarter}

The Task 4 Report was submitted to DOE as a final report. No additional work was planned nor completed during this quarter. 


\subsection{TASK 5 BENCH-SCALE PROCESS TESTING}

\subsection{Overview and Scope}

The overall goal of Task 5, "Bench-Scale Process Testing" is to develop the necessary unit operation design and process performance data required to 1$)$ reduce or eliminate the technical and engineering uncertainties of the preliminary 20TPH advanced location semi-works plant and 2) design, build and operate a 2-3 TPH advanced flotation POC module.

The unit operation performance and process design information required to support development of the advanced flotation process is being examined in a multi-tier program at B\&W and Process Technology, Inc. Laboratory scale studies are being conducted in several key process areas - conventional precleaning of the raw coal, microgrinding of the pre-cleaned coal, advanced froth flotation of the fine coal and dewatering of the product streams. The results of these studies are then being used to guide small, semi-continuous and continuous testing of the key unit operations at approximately $100 \mathrm{lb} / \mathrm{hr}$.

The bench-scale and semi-continuous process design evaluation test programs will provide detailed information for developing process material and energy balances. The material balance data will be used to correctly design and size the equipment for the POC module. The energy balance information will allow for estimation the cost effectiveness of the design.

The bench-scale test programs will also identify the optimum conditions for microgrinding the coal for maximum pyritic sulfur rejection in advanced flotation and the most promising advanced flotation technique which will then be integrated into the overall processing scheme. The $100 \mathrm{lb} / \mathrm{hr}$ test program will provide verification of the 1 aboratory tests results and demonstration that these results can be scaled-up for application in the 20TPH semiworks plant design.

Both the bench-scale, semi-continuous and continuous process design evaluation tests will serve as critical reviews of the preliminary process flowsheet. Process deficiencies and 1 imitations discovered in these programs will require modification of the original conceptual flowsheet. This information will aid in identifying solutions to the successful implementation of advanced flotation technology.

The bench-scale and process testing consists of eleven major subtasks performed over a period of 12 months.

\subsection{Review of Work Completed This Quarter}

This task has been completed and the results of this task are reported in the Task 7 report. No additional work was planned nor completed during this quarter. 


\subsection{COMPONENT AND UNIT OPERATIONS DEVELOPMENT}

\subsection{Overview and Scope}

The Task 6 effort involves three main elements including column cell development, flotation circuit testing and flotation cell modeling. The work outlined is to research column designs and operation parameters in developing an optimized column flotation cell (OCFC) to meet the overall program objectives. The test results obtained through this effort will be evaluated against the results obtained from the round-robin test program in Task 5. Any design parameters or operating conditions that are unique with the round-robin test winner that were not evaluated as part of the optimized column development work will be reviewed and tested so as to incorporate all possible scenarios in presenting DOE with the best available flotation process for use in the 2 to 3 ton per hour POC.

Following development of the OCFC, various flotation circuit configurations will be evaluated determine the "best" circuit design for the 2 to 3 ton per hour POC. Single and multiple stage flotation, grab and run, rougher/scavenger/cleaner, etc., test circuits will be tested as part of this effort. Upon completion of this test work, the "best" possible flotation cell will have been tested in a number of possible flotation circuit designs to possibly provide the "best" flotation approach in meeting the design criteria.

In conjunction with the flotation test effort, model development work will be conducted to provide a tool in evaluating the various flotation circuit configurations and in predicting flotation performance. The model will be useful in selecting operating conditions in the POC and in evaluating the performance of the POC.

6.2 Review of Work Completed this Quarter

This task has been completed and the results of this task are reported in the Task 7 Report. No additional work was planned or completed during this quarter. 


\subsection{EVALUATION OF BENCH-SCALE AND COMPONENT TEST RESULTS}

7.1 Overview and Scope

A bench-scale and component testing report was prepared and submitted to DOE after completing Task 5 and Task 6.

The report included the preparation, presentation and analysis of all the experimental data obtained in the bench-scale and component unit operations, development and testing. A comparison of the results obtained with the expected 7 imitations and deficiencies that occurred from bench-scale testing was compiled.

Following the evaluation of the bench-scale and component testing results, a residual needs analys is was prepared. This was prepared after comparing results learned in Tasks 5 and 6 with the original residual needs analysis.

Finally, a bench-scale testing summary was prepared. It specifically addressed the results of the bench-scale component testing in respect to the information necessary to define a commercially operating system. This included equipment selection, sizing, evaluation and operation to achieve both coal cleaning as we11 as the cost of system operation.

7.2 Review of Work Completed this Quarter

This task has been completed and the Task 7 Report submitted to DOE in its final version. No additional work was planned or completed during this quarter. 


\subsection{REVISED CONCEPTUAL DESIGN OF SEMI-WORKS PLANT}

\subsection{Overview and Scope}

Following DOE authorization to proceed with this task, the preliminary conceptual design of a 20TPH semi-works plant (Task 2) was redesigned from all information available at this point in the project. This update of the conceptual design incorporated information derived about fine grinding, advanced froth flotation, and dewatering in Tasks 5 and 6 . The summary report produced in Task 7 describing bench-scale test results and component development was used as a basis.

This task complied with all of the design requirements discussed in Task 2. The process flowsheet was updated with complete energy and material balances for all process flowstreams. The equipment list was updated and supplied the base for a recalculation of the factored estimate of the capital, operating and maintenance costs. In addition, differences between the designs in Task 8 and Task 2 was highlighted and their effects on process and plant design credibility, efficiency, maintenance, operation, complexity, control, performance, and economics were discussed.

ICF Kaiser Engineers, with assistance from its sub-contractors and the Technical Support Group, were responsible for the completion of this task. This design will serve as a basis for the POC design in Task 9 and the final semi-works design in Task 15.

8.2 Review of Work Completed this Quarter

This task has been completed and a final report submitted to DOE. No additional work was planned or completed during this quarter. 


\subsection{POC MODULE DESIGN}

\subsection{Overview and Scope}

In order to develop additional confidence in the conceptual design of the advanced froth flotation circuit, a 2-3 TPH Proof-of-Concept (POC) facility was necessary. During operation of this facility, the ICF KE team will demonstrate the ability of the conceptual flowsheets to meet the program goals of maximum pyritic sulfur reduction coupled with maximum energy recovery on three DOE specified coals. The POC circuit was designed to be integrated into the Ohio Coal Development's facility near Beverly, Ohio.

OCDO's facility will provide the precleaning unit operations and ICF KE will add the advanced froth flotation circuitry. The work in this task will include the POC conceptual design, flowsheet development, equipment list, fabrication and construction drawings, procurement specifications and bid packages and a facilities estimate at the completion of design. After DOE approval, the design was finalized for the next task.

\subsection{Review of Work Completed this Quarter}

This task has been completed and the Task 9 report submitted to DOE. No additional work was planned or completed during this quarter. 


\subsection{POC MODULE FABRICATION}

\subsection{Overview and Scope}

The overall objective of this task is to obtain the equipment, materials and shop labor to fabricate and assemble each of the individual modules which constitute the POC Module. The ICF KE procurement team will solicit bids, place orders, and expedite all vendors, materialmen and fabricators. Procurement will utilize the drawings and specifications produced in Task 1.9 as the basis for these activities. At the completion of the assembly procedure, a ICF KE representative will inspect and perform a functional check of each module before it leaves the shop.

Several sub-tasks have been identified for their importance in the successful completion of this task. Work will include placing purchase orders, procurement of the equipment and materials, fabrication of the modules, functionally checking the modules, shipping the modules to the jobsite and preparing the installation and maintenance manuals.

10.2 Review of Work Completed this Quarter

This task has been completed. No additional work was planned or completed during this quarter. 


\subsection{POC INSTALLATION AND START-UP}

\subsection{Overview and Scope}

This task covers the functions necessary to install and successfully start-up the POC module at the jobsite. The installation was carried out by an installation subcontractor with construction management provided by ICF KE. The start-up was supervised by ICF KE and conducted using process engineers from the entire team and craft labor supplied by the installation subcontractor.

This task includes several major subtasks which was carried out to assure a successful, on-schedule installation and start-up. ICF KE will conduct work on installation and interconnection of the modules, preparation of start-up plans and procedures, the start-up functions and the finalization of the operations manual.

DOE's TPO was kept informed of construction progress and has access to the site for inspection of the work. ICF KE's construction manager was assigned prior to the start of construction activities and maintained the job progress through on-site assessment of the work and was using the construction schedule produced in Task 9 for control.

11.2 Review of Work Completed this Quarter

Al1 construction has been completed. No additional work was planned or completed during this quarter. 


\subsection{POC TEST PLAN FORMULATION}

\subsection{Overview and Scope}

The project team will coordinate its expertise and develop a testing plan that will provide performance data, quality data, scale-up data and operating data. The plan was submitted to DOE for approval after completion of Tasks 9 and 10.

This plan, after approval/revisions, will become the final test plan. The test plan will include long term testing, steady-state operation and effects of recycle operation. The testing program will demonstrate $90 \%$ onstream capability, evaluate process control instrumentation, develop information for scale-up, demonstrate compliance with regulatory requirements, evaluate materials of construction, and determine process economics. Ancillary information such as quality of waste stream materials was gathered.

The finalized plan will include a budget and schedule to complete all required tests and to produce batches of material for testing of beneficiated coal.

12.2 Review of. Work Completed this Quarter

This Task has been completed. No additional work was planned or completed during this quarter. 


\subsection{POC OPERATION}

\subsection{Overview and Scope}

This task is the actual demonstration of the advanced froth flotation technology. A11 previous work has led to this task. ICF KE technicians and process engineers from the team will operate the plant over a 10 month period to demonstrate the capability of the technology to remove $85 \%$ of the pyritic sulfur from three different test coals while covering at least $85 \%$ of the as-mined coal's energy content.

Six major subtasks have been included to better define the overall work scope for this task. The ICF KE team will test the Pittsburgh \#8 seam, the I1linois \#6 seam and the Upper Freeport seam; the team will operate the circuit in a continuous run; the team will analyze all samples generated in those runs and will develop a plan to store and dispose of the coal and refuse products.

All 1aboratory data generated will be accessible to all team members and the DOE. The TPO will be notified of all run days in advance for the purpose of planning his trips to the site. Sufficient time will be allowed in the test plan, developed in Task 12, to permit quick analysis of data generated from a completed test before continuing to the next test.

13.2 Review of Work Completed This Quarter

This Task has been completed. No additional work was planned or completed during this quarter. 


\subsection{TASK 14 POC OPERATIONS ANALYSIS}

\subsection{Overview and Scope}

The completion of this task will result in a complete analysis of the results from all the test runs on all of the coals cleaned in the POC module. The work will include, in an organized and readily accessible manner, all available laboratory data and operating results from the Advanced Flotation technology. The information will be utilized to generate results that will be compared to the batch and semi-continuous results with respect to quality and equipment design parameters. This information will then be used for the Final Conceptual Design of the $20 \mathrm{TPH}$ semi-works facility. The results will be contained in a formal POC Testing Summary Report.

\subsection{Review of Work Completed This Quarter}

As stated above, the Task 14 report resulted in a complete analysis of the results from all the test runs on all the coals processed in the POC module. This quarterly report will highlight the results from the three seams of coal tested in the POC, Pittsburgh No. 8, Upper Freeport, and Illinois No. 6 during the demonstration operation.

\section{4-HOUR DEMONSTRATION TESTS}

The 24-hour demonstration runs are described in the following paragraphs. The tests were conducted using the best operating conditions for the heavy-media cyclone, water-only cyclone, and the mill circuit. The tests were composites of eight (8)-hour shifts.

Based on the Box-Behnken tests results, the best operating conditions were identified for each of the three base coals. These best conditions are summarized in Table 14.1. As shown, the same collector dosage (i.e., $1.0 \mathrm{lb} /$ ton) and column feed rate (i.e., 2.0 tph) were found to be best for all three coals. However, the Pittsburgh No. 8 seam coal was found to require a slightly higher air holdup than the other two coals. This indicates that the Pittsburgh No. 8 seam coal required a slightly higher frother dosage to achieve maximum performance.

Table 14.1

Test Conditions Examined During the 24-Hour Demonstration

\begin{tabular}{||c|c|c|c|c||}
\hline $\begin{array}{c}\text { Coal } \\
\text { Seam }\end{array}$ & $\begin{array}{c}\text { Plant } \\
\text { Feed Rate } \\
\text { (tph) }\end{array}$ & $\begin{array}{c}\text { Column } \\
\text { Feed Rate } \\
\text { (tph) }\end{array}$ & $\begin{array}{c}\text { Collector } \\
\text { Dosage } \\
\text { (1b/ton) }\end{array}$ & $\begin{array}{c}\text { Air } \\
\text { Holdup } \\
(\%)\end{array}$ \\
\hline Pittsburgh No. 8 & 3.1 & 2.0 & 1.0 & 24 \\
Upper Freeport & 2.3 & 2.0 & 1.0 & 21 \\
I11 inois No. 6 & 2.6 & 2.0 & 1.0 & 21 \\
\hline
\end{tabular}


The test data and performance calculations for the long-duration testing of the Pittsburgh No. 8, Upper Freeport, and IIlinois No. 6 seam coals are summarized in Appendices $\mathrm{H}-\mathrm{J}$, respectively.

The data obtained from the HMC circuit during the 24-hour demonstration POC tests are given in Figures 14.1 - 14.3 for each of the three base coals. The average results obtained for Btu recovery, ash rejection, and pyritic sulfur rejections are summarized in Table 14.2. Although very high Btu recoveries (>95\%) were achieved in all cases, the ash rejections were typically very poor $(<5-10 \%)$. The HMC circuit did reject a significant amount of pyritic sulfur, usually in the range of $45-60 \%$. The pyritic sulfur rejections showed considerable variability throughout the test program. These variations were found to be primarily related to fluctuations in the pyritic sulfur content of the feed coals. The long-duration test data suggest that, as a rule of thumb, the HMC circuit can be expected to reject approximately half of the pyritic sulfur. 


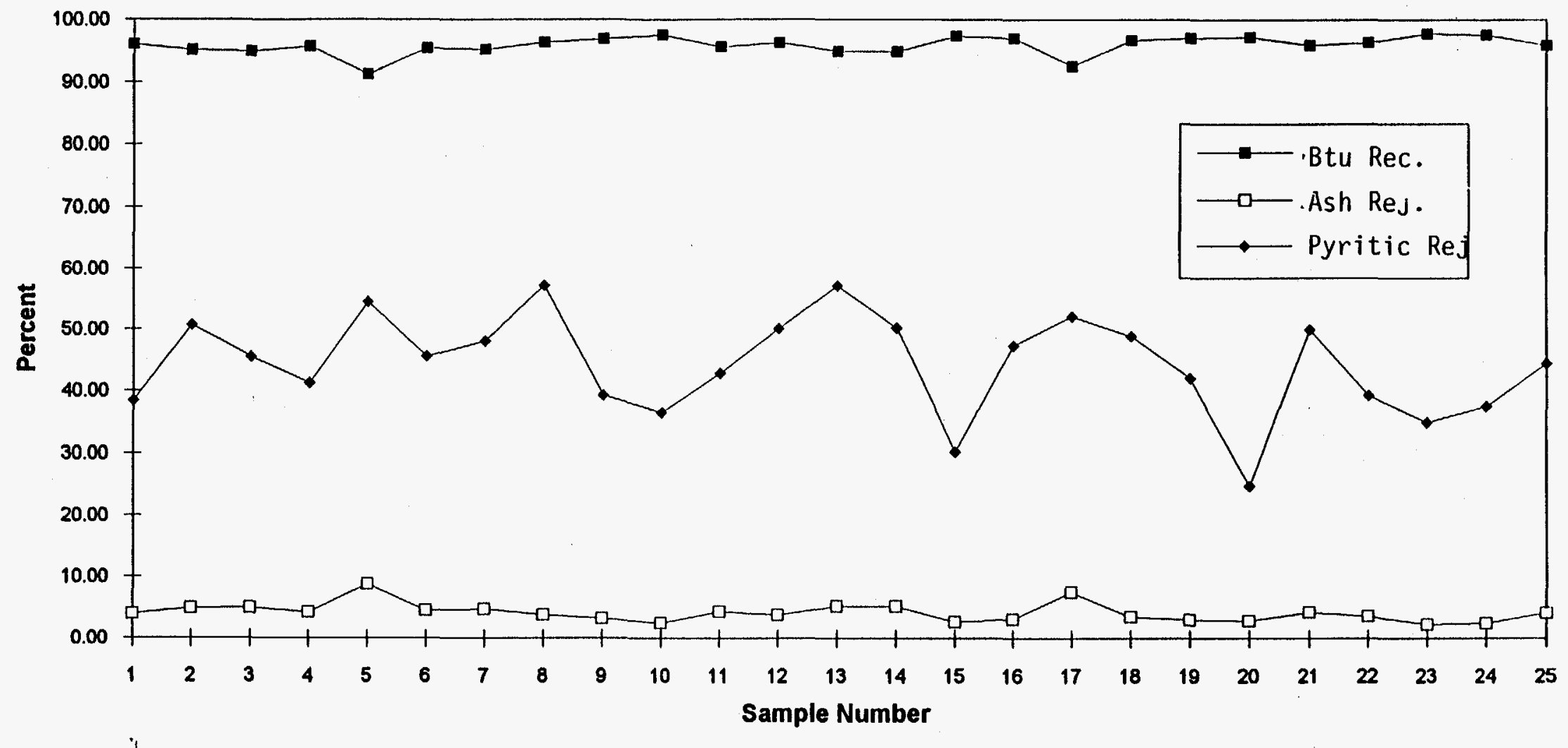




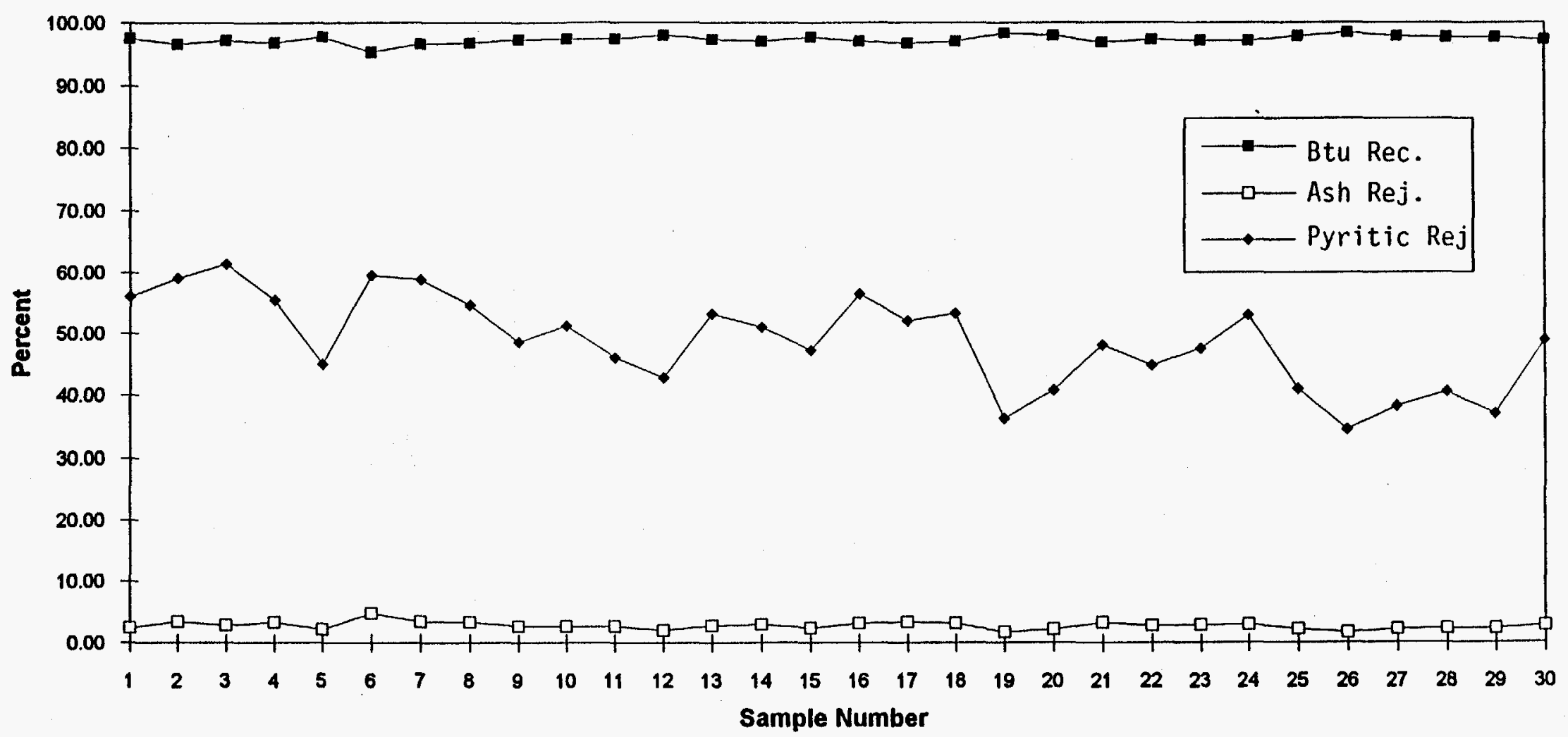

Figure 14.2

Heavy-Media Cyclone Btu Recovery, Ash Rejection, and

Pyritic Sulfur Rejection for the Long-Duration Testing of the Upper Freeport Coal 


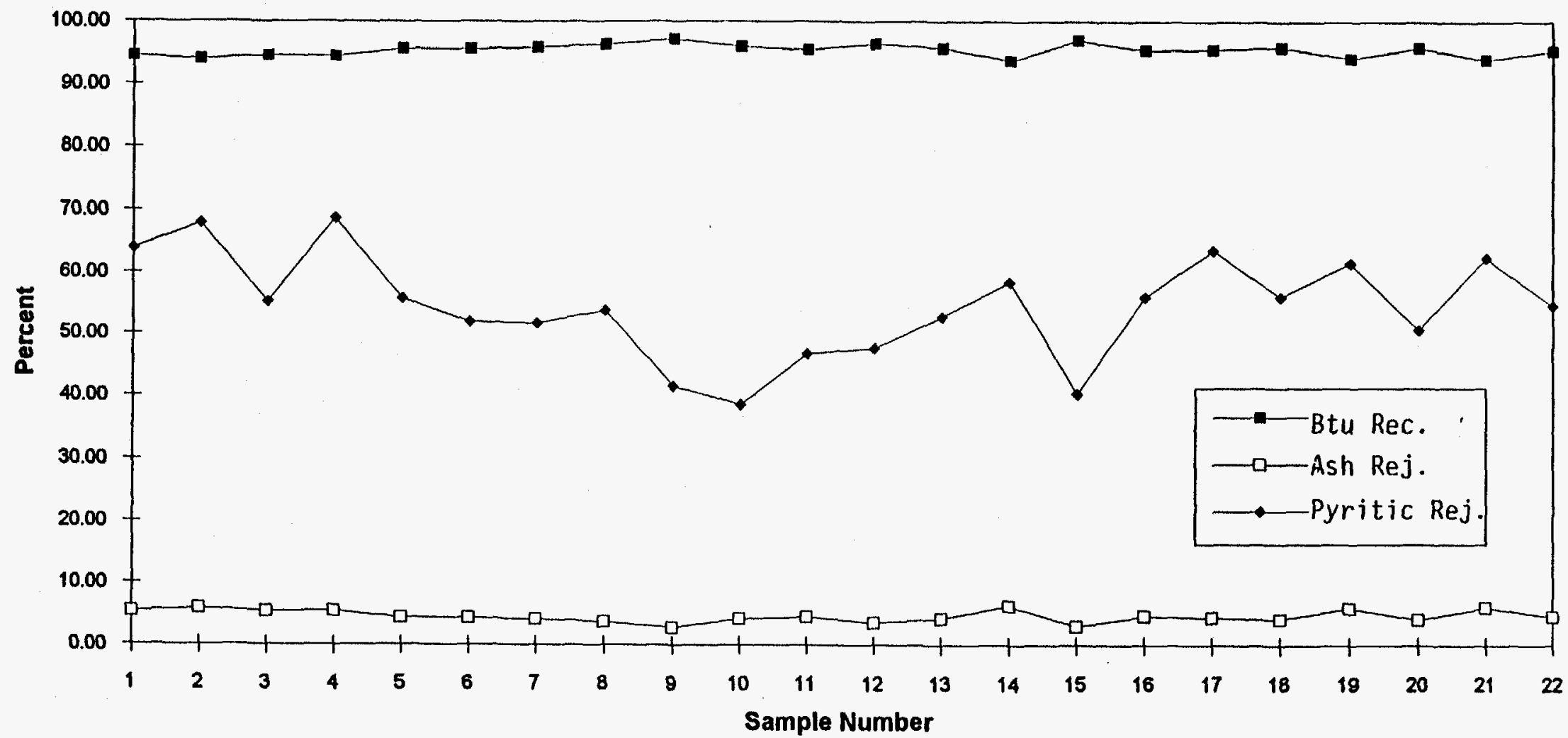

Figure 14.3

Heavy-Media Cyclone Btu Recovery, Ash Rejection, and Pyritic Sulfur Rejection for the Long-Duration Testing of the Illinois No. 6 Coal 
Table 14.2

Average 24-hour Demonstration Test Results for the HMC circuit

\begin{tabular}{|c|c|c|c|c|}
\hline Coal & $\begin{array}{c}\text { Btu } \\
\text { Recovery } \\
(\%)\end{array}$ & $\begin{array}{c}\text { Ash } \\
\text { Rejection } \\
(\%)\end{array}$ & $\begin{array}{c}\text { Pyritic } \\
\text { Sulfur } \\
\text { Rejection } \\
(\%)\end{array}$ & $\begin{array}{c}\text { Separation } \\
\text { Efficiency } \\
(\%)\end{array}$ \\
\hline Pittsburgh No. 8 & 95.9 & 4.2 & 44.3 & 40.1 \\
Upper Freeport & 95.3 & 2.7 & 48.6 & 45.9 \\
Illinois No. 6 & 95.4 & 4.6 & 54.4 & 49.8 \\
\hline
\end{tabular}

Figures 14.4 - 14.6 show the Btu recovery, ash rejection, and pyritic sulfur rejection data obtained from the WOC circuit for each of the three base coals. Average values obtained are reported in Table 14.3. The WOC circuit achieved very good Btu recoveries (95\%). However, both the ash and pyritic sulfur rejections were relatively poor. For the case of ash, rejections less than 5-10\% were typically achieved. The corresponding pyritic sulfur rejections averaged less than $30 \%$ for the Pittsburgh No. 8 coal and less than 25\% for the Illinois No. 6 Seam Coal. For the Upper Freeport Coal, pyritic sulfur rejections less than $20 \%$ were obtained. The pyritic sulfur rejected was liberated pyrite. This was removed by the water-only cyclone prior to column flotation.

Table 14.3

Average 24-hour Demonstration Test Results For the WOC circuit

\begin{tabular}{|c|c|c|c|c|}
\hline Coal & $\begin{array}{c}\text { Btu } \\
\text { Seam }\end{array}$ & $\begin{array}{c}\text { Ash } \\
\text { Rejection } \\
(\%)\end{array}$ & $\begin{array}{c}\text { Pyritic } \\
\text { Sulfur } \\
\text { Rejection } \\
(\%)\end{array}$ & $\begin{array}{c}\text { Separation } \\
\text { Efficiency } \\
(\%)\end{array}$ \\
\hline Pittsburgh No. 8 & 96.0 & 11.7 & 29.6 & 25.6 \\
Upper Freeport & 99.1 & 4.7 & 15.3 & 14.4 \\
I17inois No. 6 & 97.8 & 9.3 & 22.6 & 20.4 \\
\hline
\end{tabular}

The results obtained from the column circuit during the 24-hour demonstration tests are shown in Figures 14.7 - 14.9. Average performance values are provided in Table 14.4. As with the other POC unit operations, the column achieved very good Btu recoveries $(90 \%)$. The ash rejections were also found to be very good, usually in the order of $60-75 \%$. The corresponding pyritic sulfur rejections were somewhat lower $(30-45 \%)$, although still quite reasonable. 

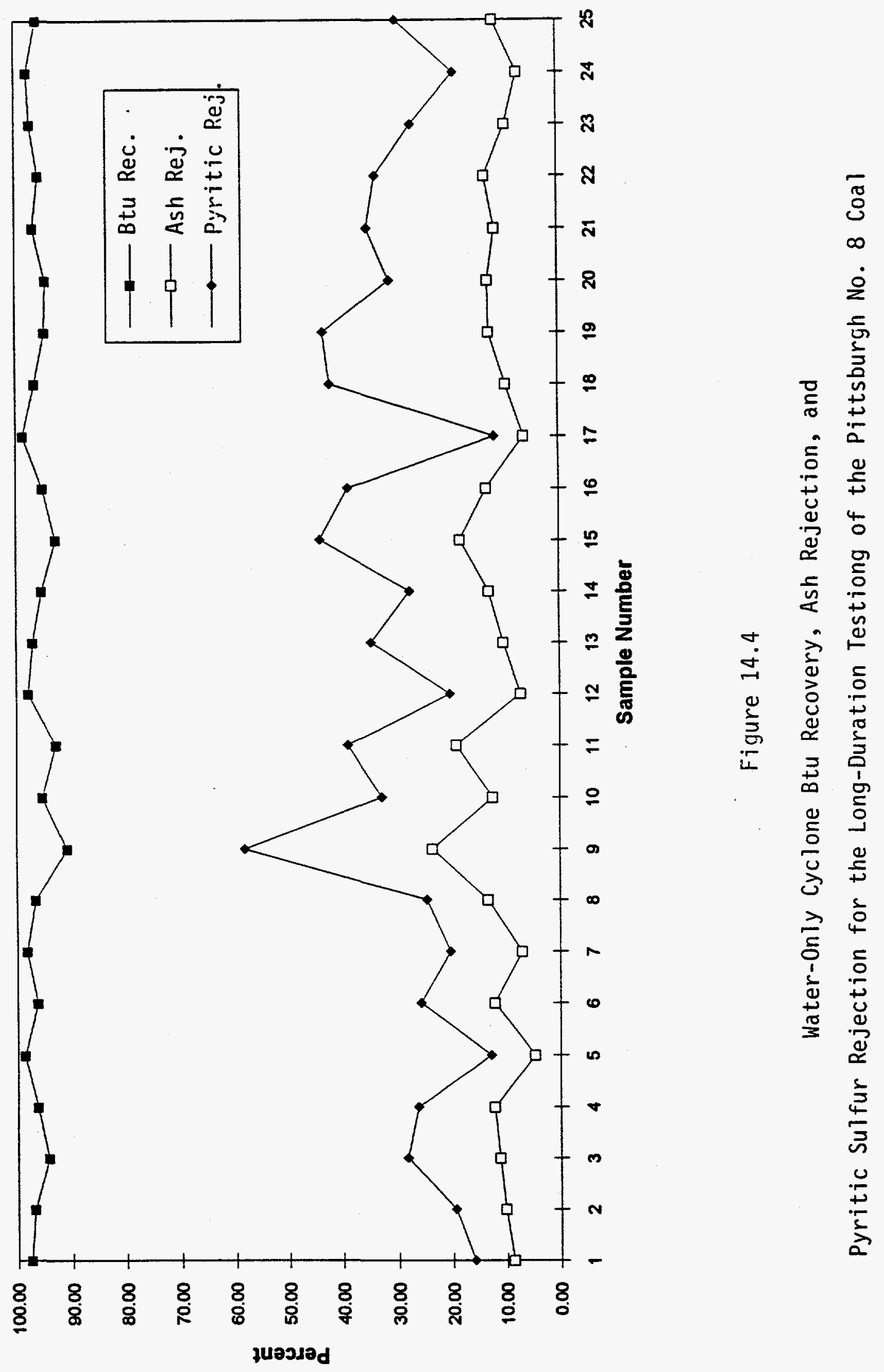


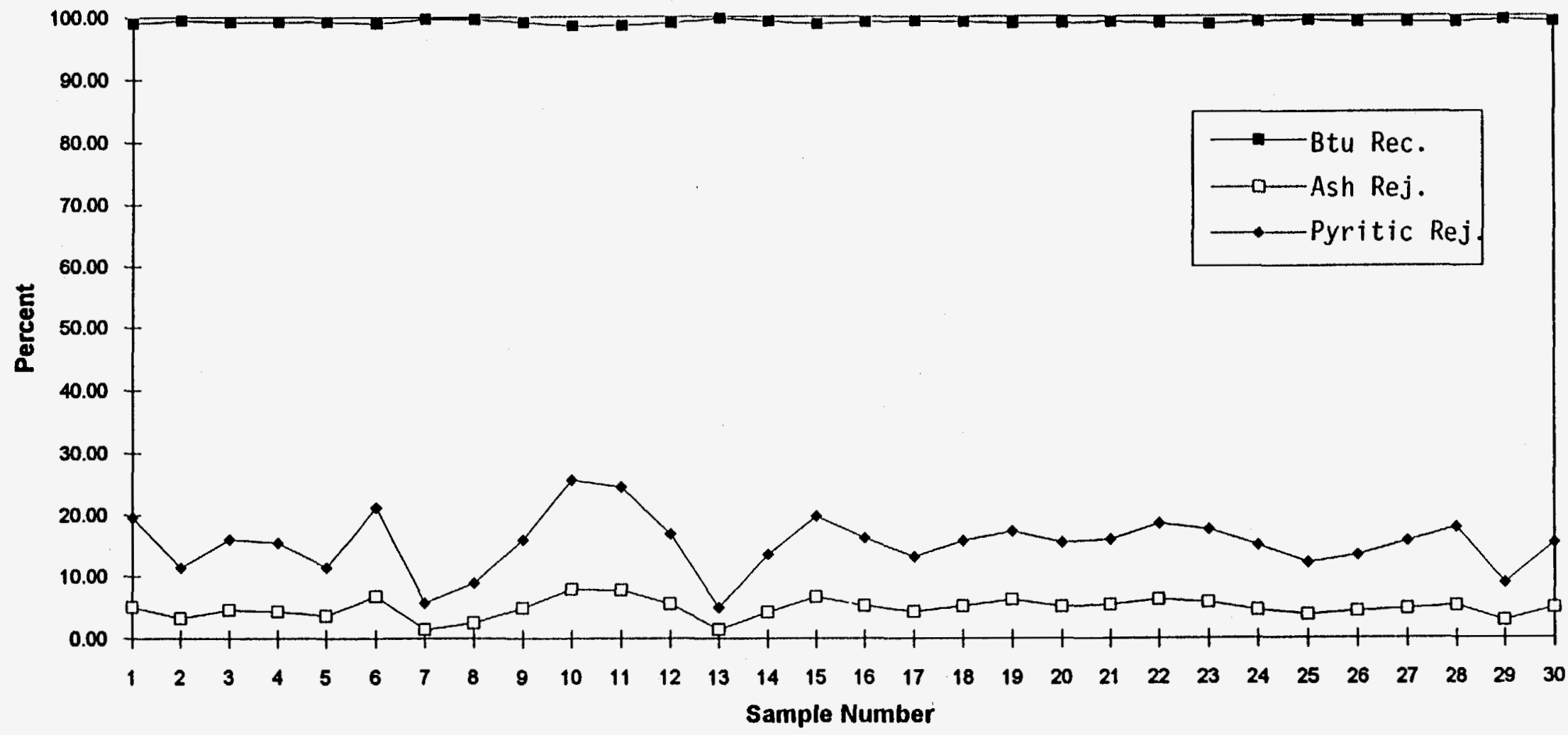

Figure 14.5

Water-Only Cyclone Btu Recovery, Ash Rejection, and Pyritic Sulfur Rejection for the Long Duration Testing of the Upper Freeport Coal 


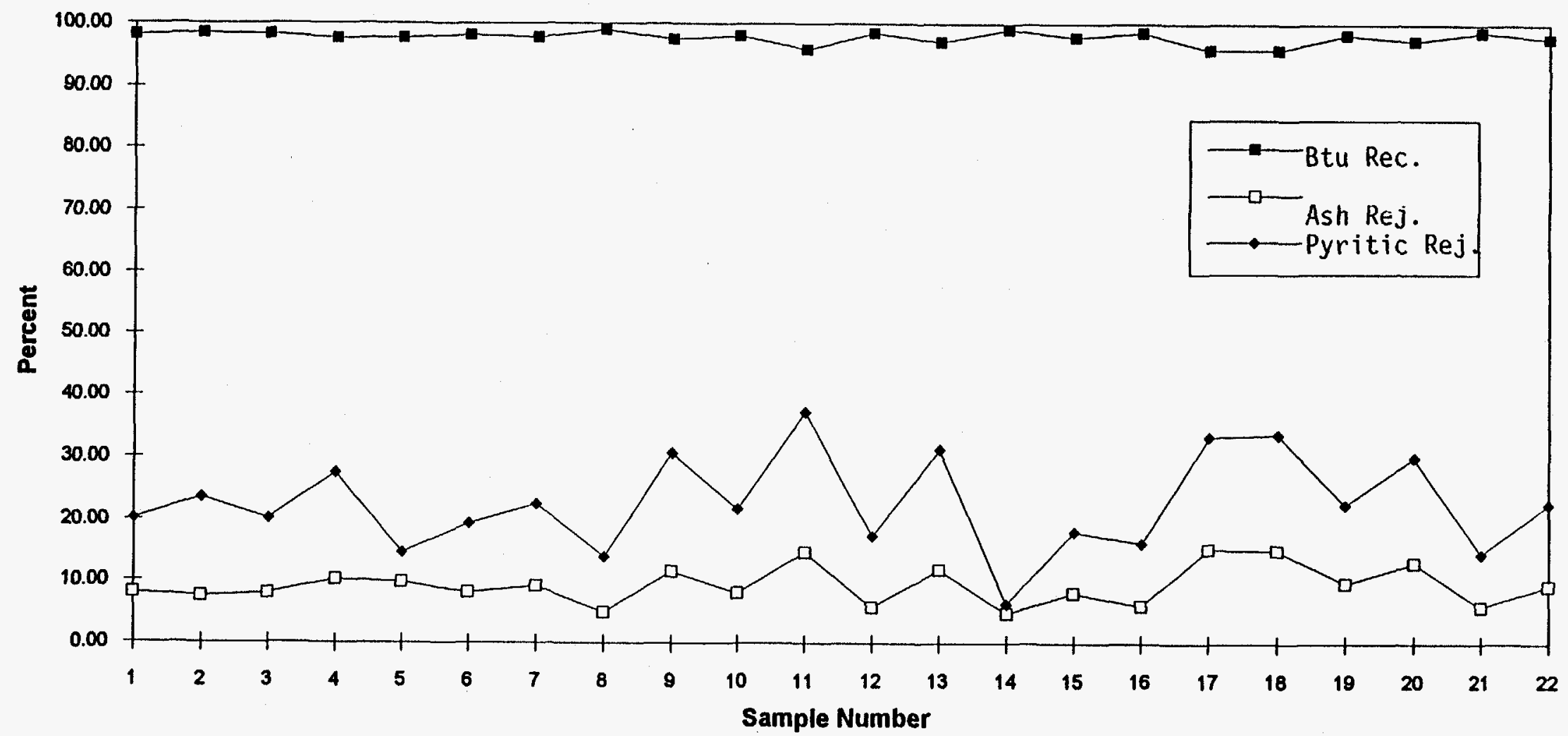

Figure 14.6

Water-Only Cyclone Btu Recover, , Ash Re Rection, and $^{\prime}$

Pyritic Sulfur Rejection for the Long-Uuration Testing of the Illinois No. 6 Coal 

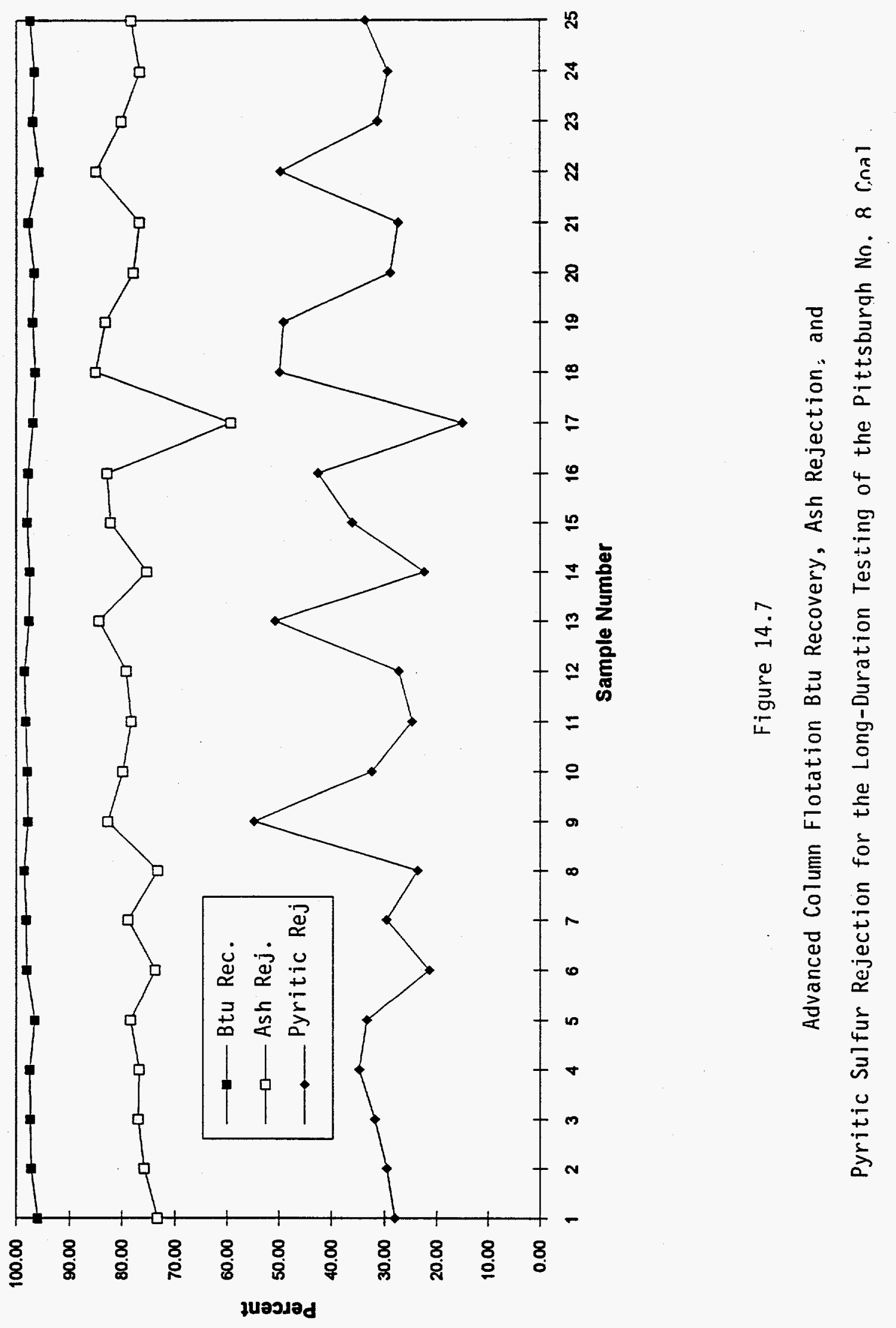


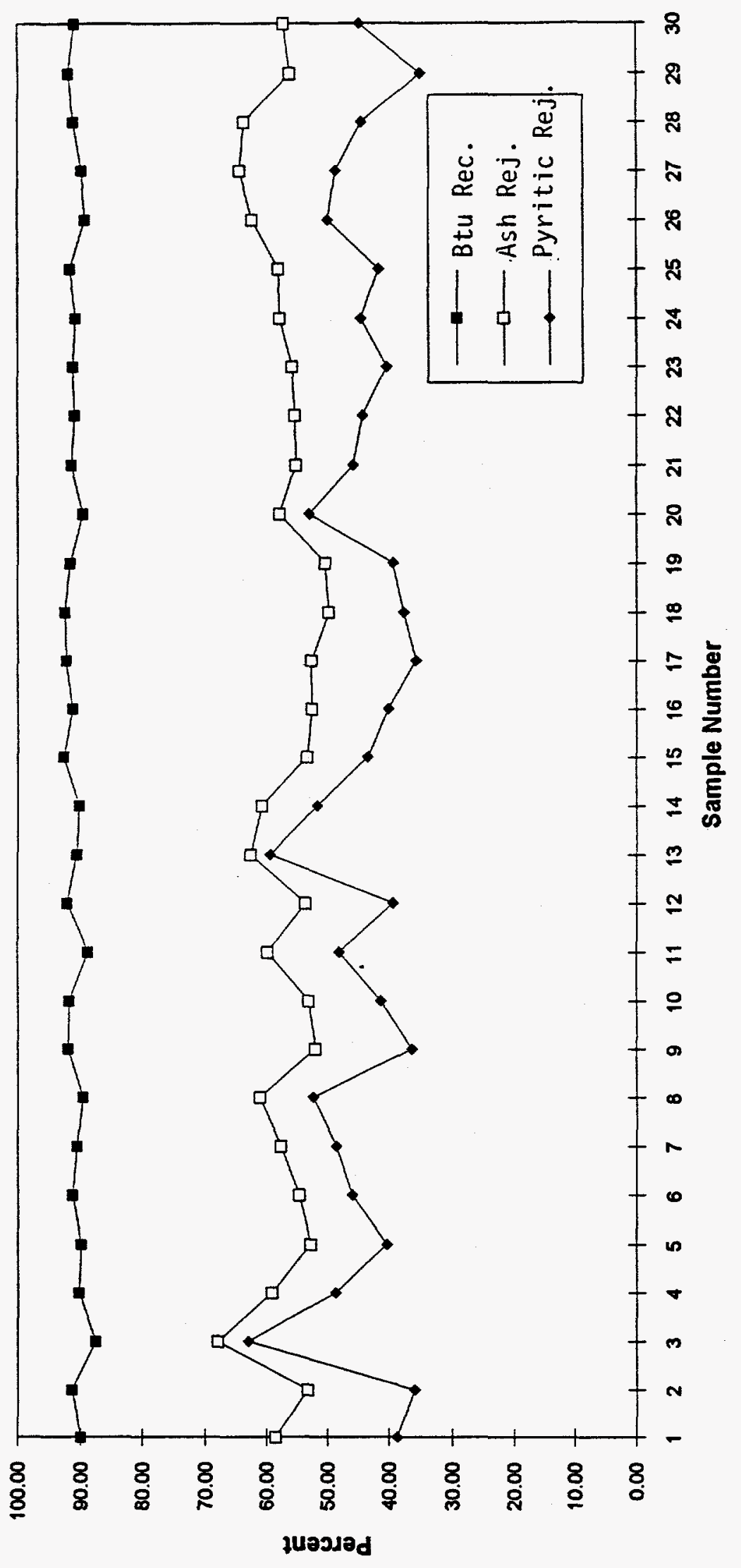

ร్త

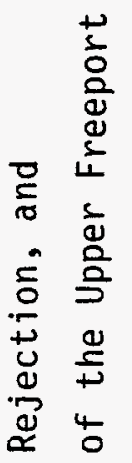

高

$\rightarrow \stackrel{\text { g }}{0}$

$\infty$ خे

守

岂 䎡

는

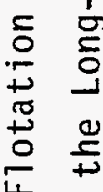

产 额

옹

용

岕

운

$\frac{5}{4}$
$\frac{5}{5}$
$\frac{4}{4}$
$\frac{1}{2}$
$\frac{2}{2}$ 


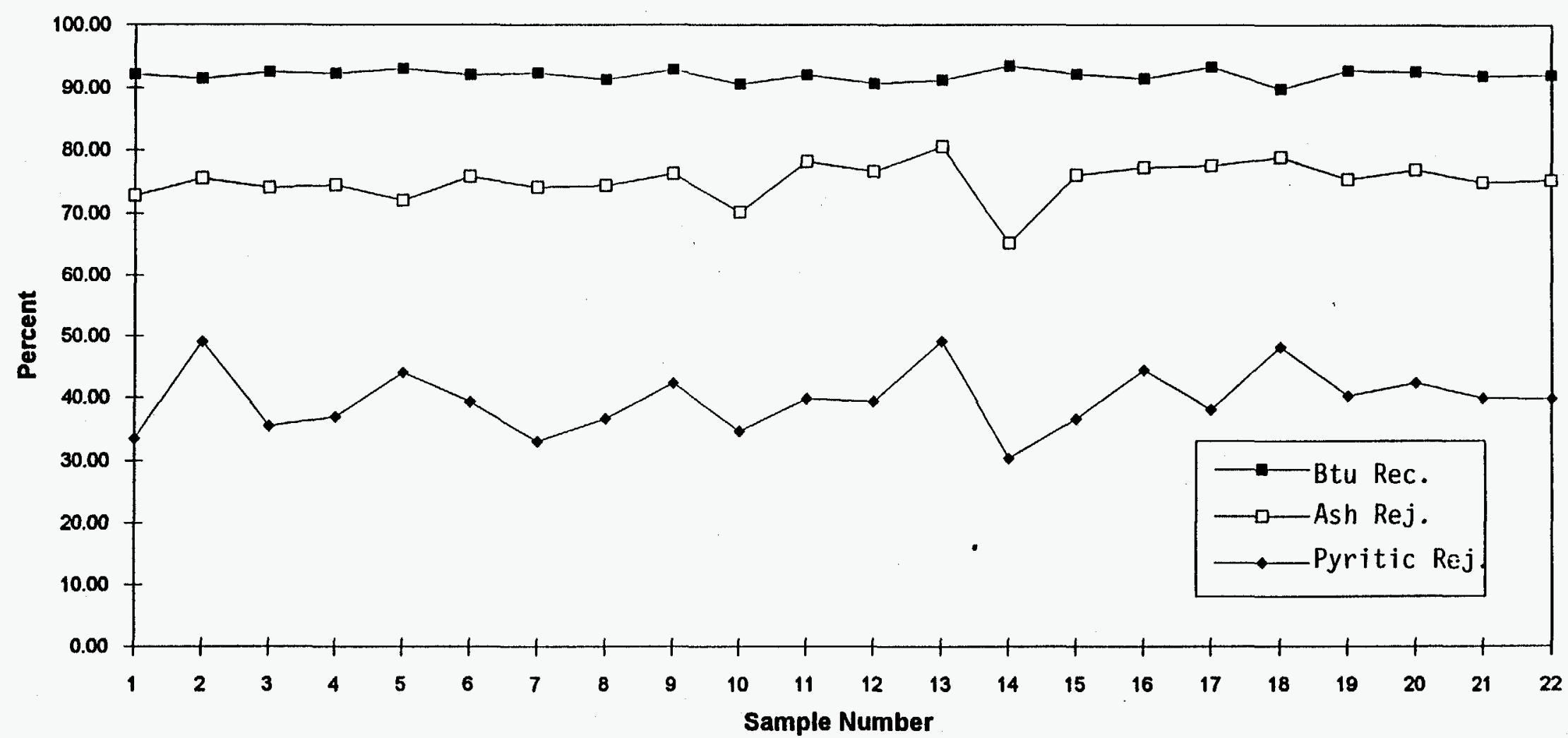

Figure 14.9

Acivanced Column Flotation Btu Recovery, Ash Rejection, and Pjricic Suifur Rejection for the Long-Duration Testing of the Illinois No. 6 Coal 
Table 14.4

Average 24-hour Demonstration Test Results for the Column Circuit

\begin{tabular}{|c|c|c|c|c||}
\hline $\begin{array}{c}\text { Coal } \\
\text { Seam }\end{array}$ & $\begin{array}{c}\text { Btu } \\
\text { Recovery } \\
(\%)\end{array}$ & $\begin{array}{c}\text { Ash } \\
\text { Rejection } \\
(\%)\end{array}$ & $\begin{array}{c}\text { Pyritic } \\
\text { Sulfur } \\
\text { Rejection } \\
(\%)\end{array}$ & $\begin{array}{c}\text { Separation } \\
\text { Efficiency } \\
(\%)\end{array}$ \\
\hline $\begin{array}{l}\text { Pittsburgh No. 8 } \\
\text { Upper Freeport }\end{array}$ & 97.3 & 78.0 & 33.4 & 30.7 \\
I11 inois No.6 & 90.9 & 56.8 & 44.5 & 35.3 \\
\hline
\end{tabular}

Based on the results obtained from the HMC, WOC, and column circuits, the overall performance of the POC circuit was calculated. These results are summarized in Figures 14.10 - 14.12 for each of the three base coals. The average performance values are given in Table 14.5 for reference purposes. As shown, the POC circuitry typically achieved Btu recoveries in the range of $85-90 \%$. Corresponding ash rejections were in the order $90 \%$ for the Pittsburgh No. 8 and Illinois No. 6 coals, and $70 \%$ for the Upper Freeport coal. Average pyritic sulfur rejections were typically in the range of $73-79 \%$ for all three coals. These results indicate that the proposed POC circuit is quite effective in reducing both the ash and pyritic sulfur contents of the base coal samples with little loss in heating value.

Table 14.5

Average 24-hour Demonstration Test Results for the Overall Plant Circuit

\begin{tabular}{|c|c|c|c|c||}
\hline $\begin{array}{c}\text { Coal } \\
\text { Seam }\end{array}$ & $\begin{array}{c}\text { Btu } \\
\text { Recovery } \\
(\%)\end{array}$ & $\begin{array}{c}\text { Ash } \\
\text { Rejection } \\
(\%)\end{array}$ & $\begin{array}{c}\text { Pyritic } \\
\text { Sulfur } \\
\text { Rejection } \\
(\%)\end{array}$ & $\begin{array}{c}\text { Separation } \\
\text { Efficiency } \\
(\%)\end{array}$ \\
\hline $\begin{array}{l}\text { Pittsburgh No. 8 } \\
\text { Upper Freeport } \\
\text { I11 inois No. 6 }\end{array}$ & 89.5 & 91.9 & 73.7 & 63.2 \\
\hline
\end{tabular}

A 2 TPH POC test circuit was constructed to test the effectiveness of an advanced multi-stage processing scheme for the deep cleaning of moderate-to-high sulfur coals. Using this circuit, parametric studies were performed to investigate the effects of various operating parameters on circuit performance. After identifying the best operating conditions for each coal, long-duration tests were performed to validate the steady-state performance of the POC circuitry. For the Pittsburgh No. 8 coal, an Btu recovery of nearly $90 \%$ was achieved at ash and pyritic sulfur rejections of $92 \%$ and $74 \%$, respectively. A slightly lower Btu recovery of $87 \%$ and significantly lower ash rejection of $69 \%$ was achieved for the Upper Freeport coal. However, a slightly higher pyritic sulfur rejection 


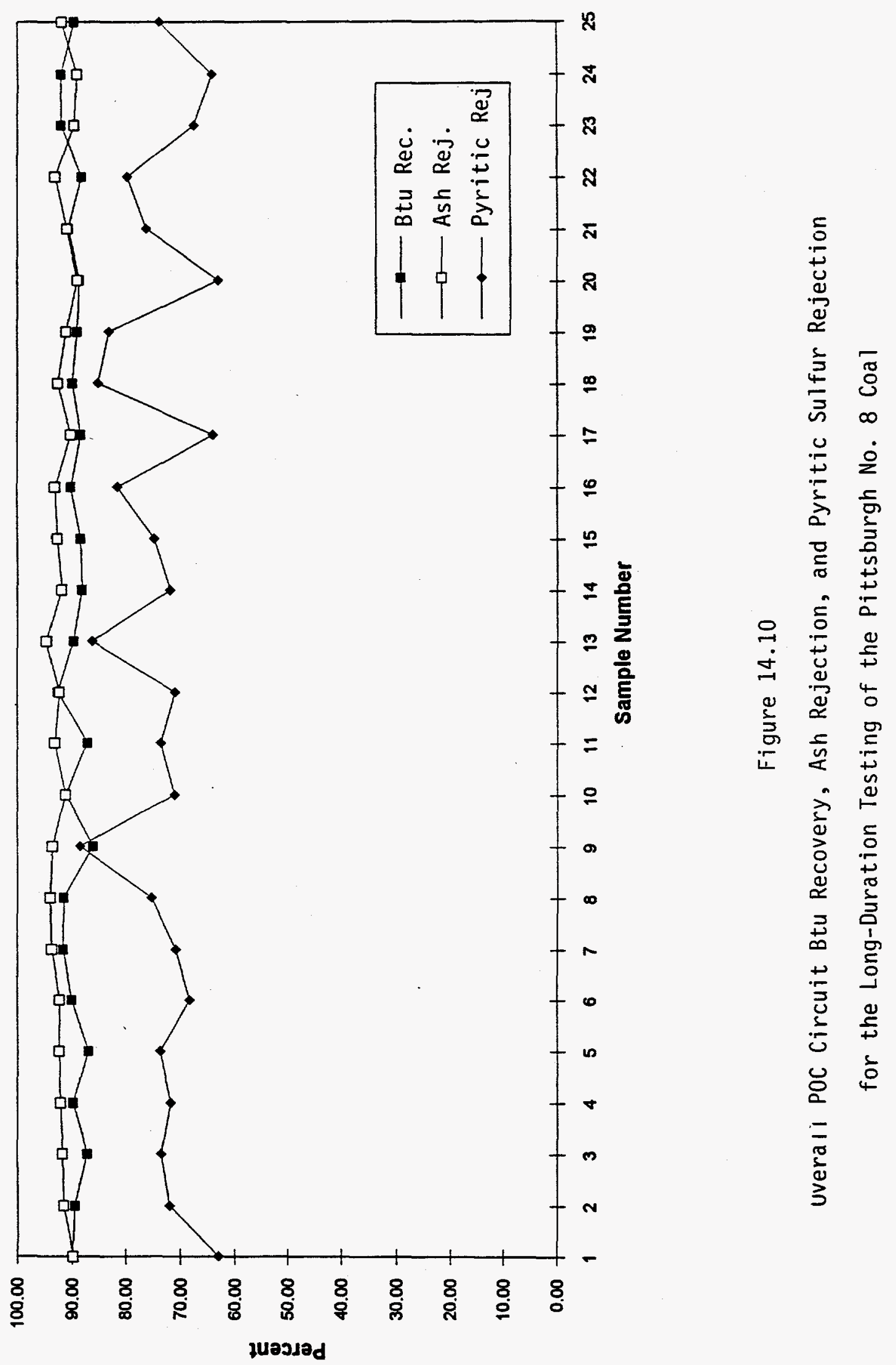

Page 30 


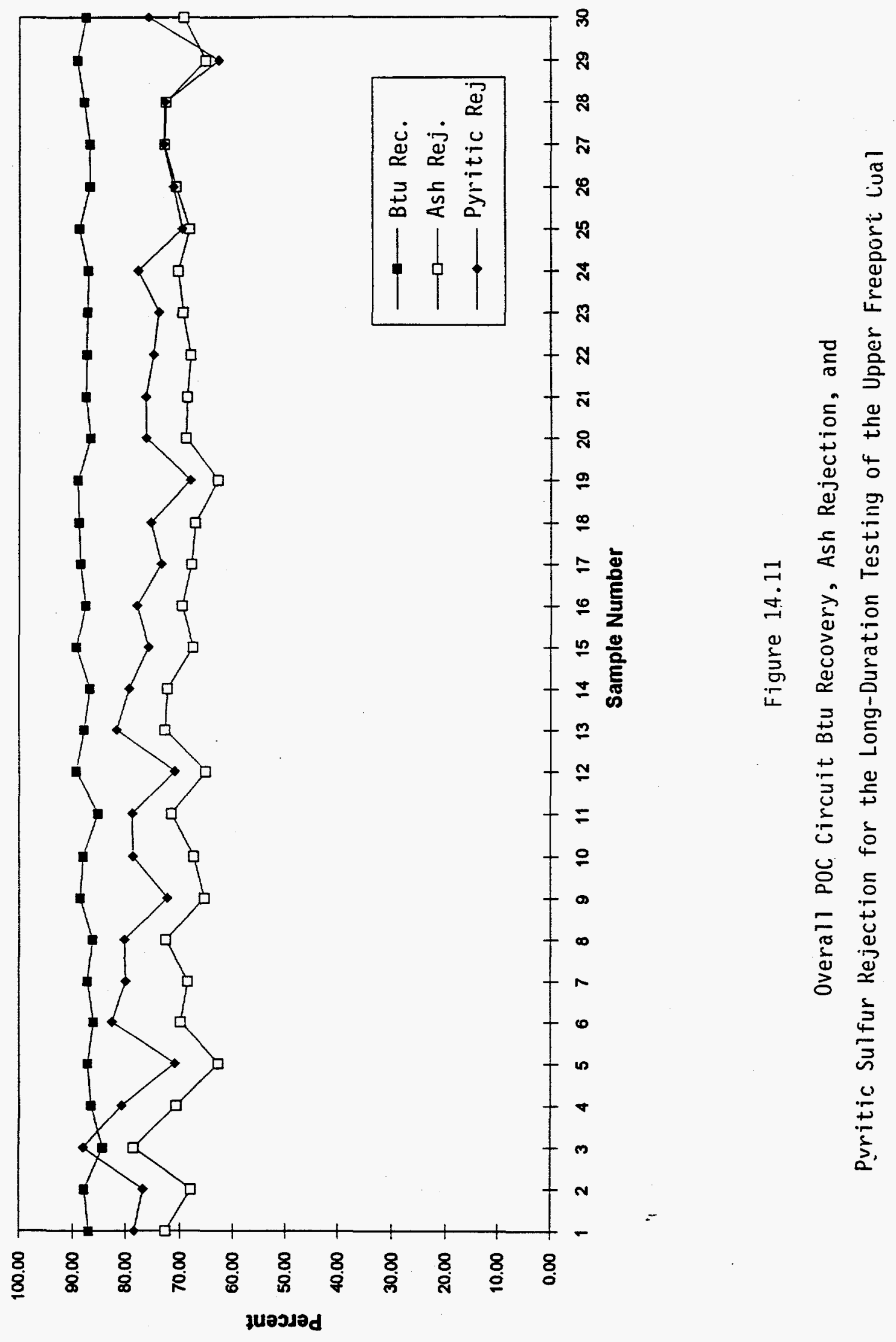

Page 31 


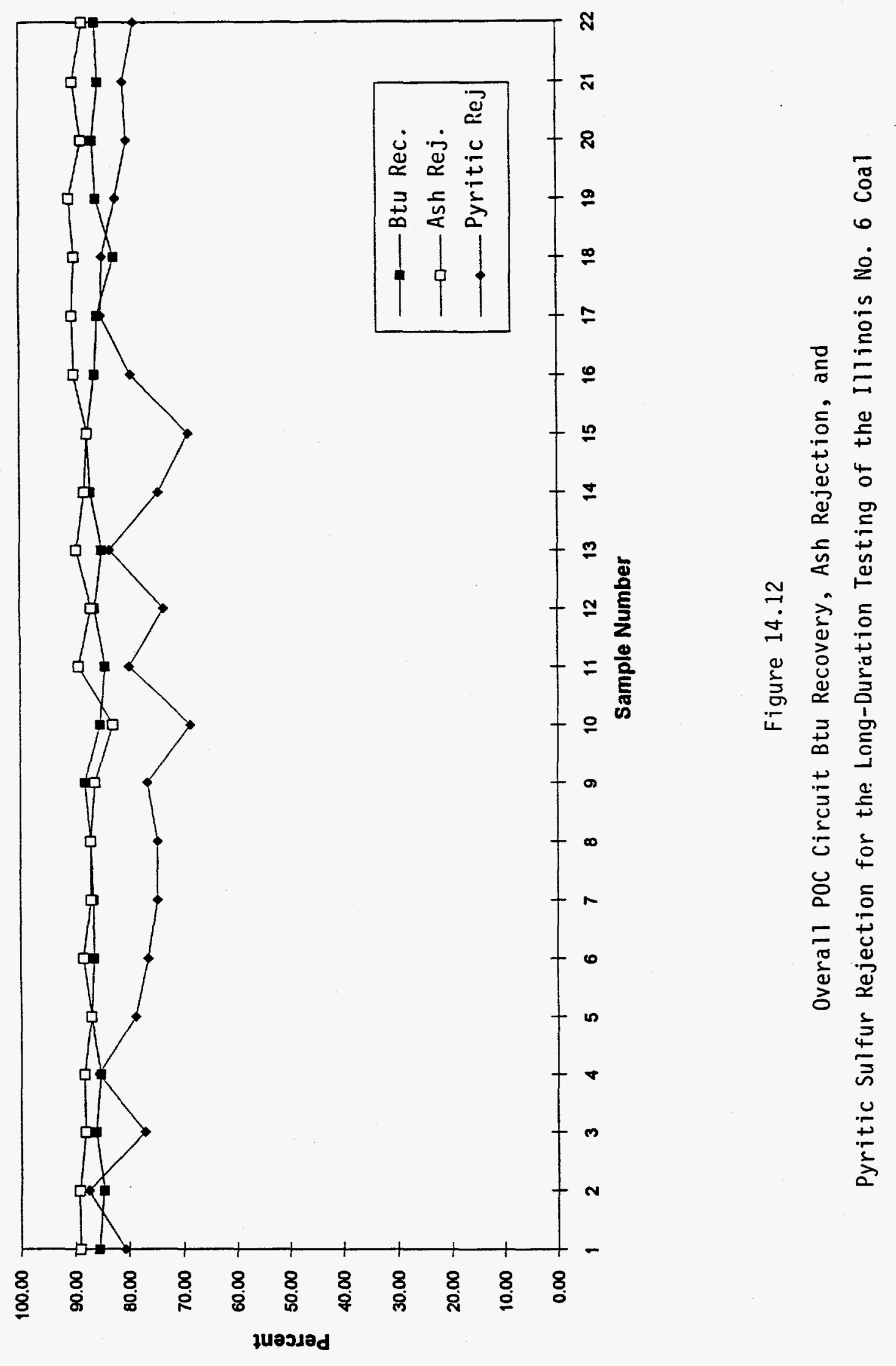

Page 32 
of $76 \%$ was obtained. Although the lowest overall Btu recovery of $85 \%$ was obtained for the Illinois No. 6 coal, a significantly higher ash rejection (88\%) and pyritic sulfur rejection (79\%) was achieved for this particular coal.

Table 14.6 shows a comparison of the results with the project objectives set forth at the beginning of the contract. Generally, the Btu recovery met or exceeded the objective of $85 \%$ Btu recovery. The pyritic sulfur rejection was somewhat lower than the objective by about $10 \%$. The Btu recovery and pyritic sulfur rejection are inverse, i.e. the higher the Btu recovery, the lower pyritic sulfur rejection. Therefore, if the Btu recovery were reduced for the Pittsburgh No. 8 and Upper Freeport to $85 \%$, the pyritic sulfur rejection would increase upwards to approach that of the Illinois No. 6 product. In no case would pyritic sulfur rejection exceed $80 \%$ and still maintain $85 \%$ Btu recovery.

The same scenario holds true for the final ash of the product. As Btu recovery is reduced, the ash in the final product would decrease. Again, at $85 \%$ Btu recovery, the goal of $6 \%$ ash probably would not be obtained. Ash in the final product is a function of the coal's mineral matter distribution.

The surface moisture of the product and the reject were established to be $30 \%$ and $35 \%$ respectively. As Table 14.6 shows, in no case were these objectives fulfilled. In the case of the product, the dewatering device selected (hyperbaric filter) did not continuously operate, and for this reason was removed from the POC. A solid bowl centrifuge was then used to dewater the final product. These are the moisture results reported. The hyperbaric filter product, when the unit operated, was in the range of $25-30 \%$ surface moisture. The reject reported is the product of the refuse centrifuge only. The fine refuse was disposed of in an impoundment. The dewatering device selected for fine refuse dewatering was a belt press. This unit operation performed as designed and produced a final product with a moisture of $30 \%$. However, because of contamination of the recirculated water by excess flocculant usage for the machine, it was removed from the POC.

Table 14.6

Summation of 24-Hour Demonstration Results

\begin{tabular}{||c|c|c|c|c|}
\hline & Objective & $\begin{array}{c}\text { Pittsburgh } \\
\text { No. 8 }\end{array}$ & $\begin{array}{c}\text { Upper } \\
\text { Freeport }\end{array}$ & $\begin{array}{c}\text { I11inois } \\
\text { No. 6 }\end{array}$ \\
\hline BM Rec. \% & 85 & 89.5 & 87.5 & 85.8 \\
\hline Pyr. Rej.\% & 85 & 73.7 & 75.8 & 78.6 \\
\hline Product Ash \% & 6 & 7.6 & 10.3 & 7.20 \\
\hline Product Mst.\% & 30 & 35.0 & 35.0 & 35.0 \\
\hline Reject Mgt. \% & 30 & $10.0 *$ & $10.0 *$ & $10.0 *$ \\
\hline
\end{tabular}

*Does not include fine reject material. 


\section{ENVIRONMENTAL PERFORMANCE}

The environmental performance of the POC facility was as anticipated. There were no adverse impacts to the environment during the operation of the POC. The reagents used during operation, kerosene, MIBC frother, anionic flocculant, cationic coagulant and with the Upper Freeport, sodium hydroxide, are standard reagents used in commercial coal preparation plants every day. The reagents' storage and handling were according to the environmental audit plan and complied completely with the Ohio Power Company's rules and regulations which are stricter than the current Federal, state, and local regulations.

Refuse disposal was handled by the Ohio Power Company. The coarse refuse was hauled by truck to the present refuse storage pile. The fine refuse was pumped to the present refuse impoundment. The monitoring of the water outfalls, according to the Federal and state water permits, showed no violations during the operation of the POC as a result of the refuse material from the plant.

The clean coal was stored and reclaimed by the Ohio Power Company and delivered to a power station. Again, the monitoring of the water outfalls according to the Federal and State water permits, showed no violation during the operation of the POC.

Air quality was maintained at permitted levels. The POC reactivated pollution control dust collectors and during the operation of the POC no violations for Federal and state air pollution permits occurred.

Based on the above, if proper precautions are instituted at the beginning of a project incorporating the advanced flotation circuit there should be no impact on the water or air quality in and around the plant.

\section{ENGINEERING PERFORMANCE}

The engineering performance of the unit operations in the precleaning and advanced circuits were according to the initial design except for the grinding mill. A unit operation-by-unit operation discussion is contained in the Task 14 report. The report describes whether the unit operation conformed to the design criteria, and if not, what should be done in order to meet the design criteria.

The conclusion that can be drawn from the operation of the POC can be divided into three topics: the precleaning circuit, the advanced circuit, and the instrumentation. The precleaning equipment is composed of conventionally-designed coal preparation equipment and should not be any problem to scale-up to the semi-works size plant. The advanced circuit has the only equipment design consideration and this concerns designing for increased recirculated load to the bal1 mill. Otherwise, this circuit should have no problems in scale-up. The conventional instrumentations presented no problems and should scale-up to the semi-works plant. The advanced instruments should 
not be included in the semi-works plant because of operating problems and/or reliability with the instruments. The only instrument to be included should be the automatic flocculant control system. The modification to be made is that the settling rate instrument needs to be a calorimeter instead of the density measurement device.

The semi-works plant should be easily scaled-up based on the experience gained in the POC operation. In fact, there were no major surprises. A philosophical adjustment developed in the disposal of the fine refuse in that an impoundment should be incorporated in the final design. Otherwise all other unit operations are scaleable to the semi-works size or greater.

The major scale-up calculations are for the advanced column flotation cel1. Table 14.7 indicates the design criteria for the advanced column.

Table 14.7

Column Design Criteria

\author{
FEED RATE $=0.0708 \mathrm{TpH} / \mathrm{FT}^{2}$ \\ WASH WATER RATE $=0.4730 \mathrm{FT} / \mathrm{MIN}$ VELOCITY DOWN \\ AIR RATE $=4.95 \mathrm{cfm} / \mathrm{FT}^{2}$ OF CELL AREA
}

These numbers agree closely with the scale-up values for column cell for larger commercial units.

In addition to the engineering design data for the unit operations, several operational variables were also determined from the POC operation. These variables were the rates of reagent usage for flotation, rates of flocculant for dewatering, and the amount of magnetite used during operation. A systematic method for all three coals was developed to reach the actual usage of the consumables during the 24-hour demonstration runs.

Magnetite consumption during operation was a function of the loss of magnetite on the refuse stream and the tailings of the magnetic separator. During the 24-hour demonstration runs, samples of the refuse streams for all three coals were analyzed for magnetite adhering to the material as it discharged out of the media circuit. In addition, the feed to the refuse static thickener was also analyzed for magnetite. This stream would contain magnetite lost from the clean coal from the heavy-media cyclone and the tailings from the magnetic separator.

Magnetite loss was determined generally on a pounds-per-ton-ofcoal feed to the media circuit. Losses were a direct measurement of the efficiency of rinsing the magnetite from the products and the efficiency of operation of the magnetic separator. The best efficiency of a magnetic separator is $99.8 \%$ magnetic recovery under the best operating conditions. This means for every one 
thousand pounds of magnetite processed in the magnetic separator, two pounds is lost to the tailings.

The normal feed rate of media to the magnetic separators during the 24-hour demonstration tests was 10,000-12,000 pounds per hour. Therefore, the loss of magnetite at peak efficiency would run 2024 pounds per hour. If the efficiency of the magnetic separator would be less than this, magnetite loss would increase. An example would be if the efficiency dropped to $99.7 \%$, the loss would be 30-36 pounds per hour. The purpose of this discussion is to explain the loss of magnetite when expressed in pounds per ton of feed appears to be totally out of control, when in fact, it was not. The POC circuit was processing 1.5-2.0 tph of feed, and the circuit was capable of processing 40-45 tph. If the same magnetite losses are assumed for both feed rates to the circuit, the pounds of magnetite lost per ton of feed changes from 9 pounds per ton to 0.45 pounds per ton.

For the Pittsburgh No. 8, all tests were reported. For the Upper Freeport, nine tests were not reported, and for the Illino is No. 6 , three tests were not reported. The average losses for the coals were as follows: 5.59 \#/Hour - Pittsburgh No. $8 ; 30.14$ \#/Hour - Upper Freeport; and 18.47 \#/ton - I11 inois No. 6. These numbers, when based on $40 \mathrm{tph}$ feed rate to the circuit, work out to be 0.14 \#/ton - Pittsburgh No. 8; 0.75 \#/ton - Upper Freeport; and 0.46 \#/ton - Illinois No. 6. Based on the calculated losses, a value of 1.2 \#/ton of feed, which is a more realistic value, will be applied for magnetite losses in the semi-works plant design.

The following tables, 14.8 - 14.10, indicate the consumption of frother - MIBC, collector - kerosene, flocculants, both anionic and cationic, and $\mathrm{pH}$ neutralizers used during the 24-hour demonstration tests. The values calculated will be applied to the Task 15 report. The data indicate a considerable reduction in frother, collector, anionic flocculant, and cationic flocculant for all of the coals from Task 8 to Task 15, except for collector for Upper Freeport and cationic flocculant for Illinois No. 6. There is an additional expense for sodium hydroxide for Upper Freeport for $\mathrm{pH}$ regulation.

\section{OPERATIONAL HISTORY}

The operational history of the precleaning circuit and the POC circuit was very enlightening. During the operation of circuits on the Pittsburgh No. 8 coal, a number of operating problems developed that were corrected to permit the operation of the facility. There were changes in several unit operations and instruments. These changes are shown on tables 14.11 and 14.12, respectively. Five of the six unit operation changes and four of the five instrument changes occurred in the POC circuit. 
Table 14.8

REAGENT CONSUMPTIONS - PITTSBURgh NO. 8

\begin{tabular}{|c|c|c|c|c|c|c|c|c|c|c|}
\hline \multirow{2}{*}{ APPLICATION } & \multicolumn{2}{|c|}{$\begin{array}{l}\text { FROTHER } \\
\text { MIBC }\end{array}$} & \multicolumn{2}{|c|}{$\begin{array}{l}\text { COLLLCTOR } \\
\text { KEROSENE }\end{array}$} & \multicolumn{2}{|c|}{$\begin{array}{l}\text { FLOCCULANT } \\
\text { ANIONIC }\end{array}$} & \multicolumn{2}{|c|}{$\begin{array}{l}\text { FLOCCULANT } \\
\text { CATIONIC }\end{array}$} & \multicolumn{2}{|c|}{$\begin{array}{l}\text { PH REGIILATOR } \\
\text { SODILM HYDROXIDE }\end{array}$} \\
\hline & $\begin{array}{c}\text { TASK } 8 \\
\text { ITON }\end{array}$ & $\begin{array}{c}\text { TASK } 14 \\
\# / \text { TON }\end{array}$ & $\begin{array}{l}\text { TASK } 8 \\
\# / \text { TON }\end{array}$ & $\begin{array}{l}\text { TASK } 14 \\
\# / \text { TON }\end{array}$ & $\begin{array}{l}\text { TASK } 8 \\
* / \text { TON }\end{array}$ & $\begin{array}{c}\text { TASK } 14 \\
: / \text { TON }\end{array}$ & $\begin{array}{c}\text { TASK } 8 \\
\# / T O N \\
\end{array}$ & $\begin{array}{c}\text { TASK } 14 \\
\| / \text { TON }\end{array}$ & $\begin{array}{l}\text { TASK } 8 \\
\text { I/TON }\end{array}$ & $\begin{array}{c}\text { IASK } 14 \\
\| / T O N\end{array}$ \\
\hline COARSE FLOTATION & 2.00 & 0.00 & 2.50 & 0.00 & - & - & - & - & - & - \\
\hline FIME FLOTATION & 2.00 & 0.00 & 2.50 & 0.00 & - & - & - & - & - & - \\
\hline ADVANCED FLDTATION & 1.00 & 1.43 & 2.00 & 1.19 & - & - & - & - & - & - \\
\hline CLEAN COAL THICKENER & - & - & - & - & 0.27 & 0.07 & 0.06 & 0.00 & 0.00 & 0.00 \\
\hline REFUSE THICKENER & - & - & - & - & 0.15 & 0.32 & 0.06 & 0.00 & 0.00 & 0.00 \\
\hline REFUSE FILTER & - & - & - & - & 0.84 & 0.00 & 0.00 & 0.00 & 0.00 & 0.00 \\
\hline TOTAL - POUNDS/TON & 5.00 & 1.43 & 7.00 & 1.19 & 1.26 & 0.39 & 0.12 & 0.00 & 0.00 & 0.00 \\
\hline
\end{tabular}

Table $\mathbf{1 4 . 9}$

Reagent Consumptions - Upper Freeport

\begin{tabular}{|c|c|c|c|c|c|c|c|c|c|c|}
\hline \multirow{2}{*}{ APPLICATION } & \multicolumn{2}{|c|}{$\begin{array}{c}\text { FROTHER } \\
\text { MIBC }\end{array}$} & \multicolumn{2}{|c|}{$\begin{array}{l}\text { COLLECTOR } \\
\text { KEROSENE }\end{array}$} & \multicolumn{2}{|c|}{$\begin{array}{l}\text { FLOCCULANT } \\
\text { ANIONIC } \\
\end{array}$} & \multicolumn{2}{|c|}{$\begin{array}{l}\text { FLOCCULANI } \\
\text { CATIONIC } \\
\end{array}$} & \multicolumn{2}{|c|}{$\begin{array}{c}\text { PH REGULATOR } \\
\text { SODIUM HYDROXIDE } \\
\end{array}$} \\
\hline & $\begin{array}{l}\text { TASK } 8 \\
\# / \text { TON } \\
\end{array}$ & $\begin{array}{c}\text { TASK } 14 \\
\# / \text { TON } \\
\end{array}$ & $\begin{array}{l}\text { TASK } 8 \\
\# / \text { TON } \\
\end{array}$ & $\begin{array}{c}\text { TASK } 14 \\
\# / T O N \\
\end{array}$ & $\begin{array}{c}\text { TASK } 8 \\
\# / \text { TON } \\
\end{array}$ & $\begin{array}{c}\text { TASK } 14 \\
\# / \text { TON } \\
\end{array}$ & $\begin{array}{l}\text { TASK } 8 \\
\# / \text { TON } \\
\end{array}$ & $\begin{array}{c}\text { TASK } 14 \\
* / \text { TON } \\
\end{array}$ & $\begin{array}{l}\text { TASK } 8 \\
\# / \text { TON } \\
\end{array}$ & $\begin{array}{c}\text { TASK } 14 \\
\text { IION }\end{array}$ \\
\hline COARSE FLOTATION & 0.07 & 0.00 & 0.00 & 0.00 & - & - & - & - & - & - \\
\hline FINE FLOTATION & 0.10 & 0.00 & 0.00 & 0.00 & - & - & - & - & - & - \\
\hline ADVANCED FLOTATION & 0.34 & 0.51 & 0.34 & 1.04 & - & - & - & - & - & - \\
\hline CLEAN COAL THICKENER & - & - & - & - & 0.15 & 0.16 & 0.03 & 0.00 & 0.00 & 0.00 \\
\hline REFUSE THICKENER & - & - & - & - & 0.33 & 0.18 & 0.11 & 0.00 & 0.00 & 10.08 \\
\hline REFUSE FILTER & - & - & - & - & 0.50 & 0.00 & 0.00 & 0.00 & 0.00 & 0.00 \\
\hline TOTAL - POUNDS/TON & 0.51 & 0.51 & 0.34 & 1.04 & 0.98 & 0.34 & 0.14 & 0.00 & 0.00 & 10.08 \\
\hline
\end{tabular}


Table 14.10

REAGENT CONSUMPTIONS - I11inois No. 6

\begin{tabular}{|c|c|c|c|c|c|c|c|c|c|c|}
\hline \multirow{2}{*}{ APPLICATION } & \multicolumn{2}{|c|}{$\begin{array}{c}\text { FROTHER } \\
\text { MIBC } \\
\end{array}$} & \multicolumn{2}{|c|}{$\begin{array}{l}\text { COLLECTOR } \\
\text { KEROSENE } \\
\end{array}$} & \multicolumn{2}{|c|}{$\begin{array}{l}\text { FLOCCULANT } \\
\text { ANIONIC } \\
\end{array}$} & \multicolumn{2}{|c|}{$\begin{array}{l}\text { FLOCCULANT } \\
\text { CAIIONIC }\end{array}$} & \multicolumn{2}{|c|}{$\begin{array}{l}\text { PH REGIII ATOR } \\
\text { SODIUM HYDROXIDE }\end{array}$} \\
\hline & $\begin{array}{l}\text { TASK } 8 \\
\# / \text { TON } \\
\end{array}$ & $\begin{array}{c}\text { TASK } 14 \\
\because / \text { TON } \\
\end{array}$ & $\begin{array}{l}\text { TASK } 8 \\
\# / \text { TON } \\
\end{array}$ & $\begin{array}{c}\text { TASK } 14 \\
\# / \text { TON } \\
\end{array}$ & $\begin{array}{l}\text { TASK } 8 \\
\# / \text { TON } \\
\end{array}$ & $\begin{array}{c}\text { TASK } 14 \\
\| / \text { TON }\end{array}$ & $\begin{array}{c}\text { TASK } 8 \\
\because / \text { TON } \\
\end{array}$ & $\begin{array}{c}\text { TASK } 14 \\
\| / T O N \\
\end{array}$ & $\begin{array}{l}\text { TASK B } \\
\| / \text { TON } \\
\end{array}$ & $\begin{array}{c}\text { IASK } 14 \\
\| / T O N \\
\end{array}$ \\
\hline COARSE FLOTATION & 1.23 & 0.00 & 2.46 & 0.00 & - & - & - & - & - & - \\
\hline FINE FLOTATION & 2.80 & 0.00 & 5.40 & 0.00 & - & - & - & - & - & - \\
\hline AOVANCED FLOTATION & 2.28 & 0.93 & 4.55 & 1.21 & - & - & - & - & - & - \\
\hline CLEAN COAL THICKENER & - & - & - & - & 0.22 & 0.17 & 0.00 & 0.00 & 0.00 & 0.00 \\
\hline REFUSE THICKENER & - & - & - & - & 0.14 & 0.21 & 0.06 & 0.88 & 0.00 & 0.00 \\
\hline REFUSE FILTER & - & - & - & - & 0.86 & 0.00 & 0.00 & 0.00 & 0.00 & 0.00 \\
\hline TOTAL - POUMDS/TON & 6.31 & 0.93 & 12.41 & 1.21 & 1.22 & 0.38 & 0.06 & 0.88 & 0.00 & 0.00 \\
\hline
\end{tabular}




\begin{tabular}{|c|}
\hline $\begin{array}{c}\text { TABLE } 14.11 \\
\text { UNIT OPERATIONS CHANGES }\end{array}$ \\
\hline $\begin{array}{l}\text { 1. Clean-Coal Thickener - Added spray water systems } \\
\text { to eliminate froth. }\end{array}$ \\
\hline $\begin{array}{l}\text { 2. Refuse Belt Press - The addition of flocculant } \\
\text { contaminated the recirculated water. As a result, this } \\
\text { unit was shut down. }\end{array}$ \\
\hline $\begin{array}{l}\text { 3. Conventional Flotation - Testing of the conventional } \\
\text { flotation resulted in overdosing the cells to ensure } \\
\text { maximum Btu recovery. The overdosing caused a } \\
\text { buildup of frother in the recirculated water that } \\
\text { poisoned the system. These units were shut down. }\end{array}$ \\
\hline $\begin{array}{l}\text { 4. Clean-Coal Filter - Operational difficulties were } \\
\text { encountered with the hyperbaric filter because of the } \\
\text { discharge system. When operational, the filter produced } \\
\text { a product in the } 22-25 \% \text { surface moisture, but could not } \\
\text { be continuously operated. The unit was shut down. }\end{array}$ \\
\hline $\begin{array}{l}\text { 5. Grinding System - Numerous changes made to the } \\
\text { classifying cyclones configurations resulted in an } \\
\text { acceptable classification point. However, the ball mill } \\
\text { was undersized for the feed rate required to operate, } \\
\text { resulting in a coarser grind. }\end{array}$ \\
\hline $\begin{array}{l}\text { 6. Varisieve Addition - An additional sizing device was } \\
\text { added to the classification circuit for the ball mill to } \\
\text { eliminate recycling of minus }-200 \text { mesh pyrite. }\end{array}$ \\
\hline
\end{tabular}

\begin{tabular}{|c|}
\hline $\begin{array}{c}\text { TABLE } 14.12 \\
\text { INSTRUMENT CHANGES }\end{array}$ \\
\hline $\begin{array}{l}\text { 1. Automatic Floc Control - Numerous attempts were } \\
\text { made to make operational an automated floc control } \\
\text { system. They were never completely successful. The } \\
\text { turbidity meter worked, but the settling rate device did } \\
\text { not. }\end{array}$ \\
\hline $\begin{array}{l}\text { 2. Ash Analyzer - Despite our efforts, the ash analyzer } \\
\text { never operated properly. Efforts to obtain results for } \\
\text { the pyrite meter were unsuccessful. The samples to the } \\
\text { analyzer were too dilute to register. }\end{array}$ \\
\hline $\begin{array}{l}\text { 3. Particle Size Analyzer - We were unable to make the } \\
\text { particle size analyzer operate properly. Over time, the } \\
\text { unit would lose calibration. }\end{array}$ \\
\hline $\begin{array}{l}\text { 4. Thermal Air Flow Meter - For whatever reason, the } \\
\text { air lines on which the meters were mounted contained } \\
\text { water, even though there was an air dryer in the } \\
\text { compressed air system. These units were removed. }\end{array}$ \\
\hline $\begin{array}{l}\text { 5. Orifice Plate Air Flow Meter - These instruments } \\
\text { were installed to replace the above and were operated } \\
\text { successfully. }\end{array}$ \\
\hline
\end{tabular}

The plant availability during the 24-hour demonstration test points out the reliability of the POC installation. The availability was calculated as the number of minutes of downtime divided by the total number of minutes of operation. Table 14.13, shows the total downtime, operating time and plant availability percentage.

TABLE 14.13

Plant Availability

\begin{tabular}{||c|c|c|c|}
\hline Coal Seam & DownTime - Min & $\begin{array}{c}\text { Operating Time } \\
- \text { Min }\end{array}$ & Availability \% \\
\hline Pittsburgh No. 8 & 230 & 11302 & 98.0 \\
\hline Upper Freeport & 377 & 14280 & 97.4 \\
\hline Illinois No. 6 & 1455 & 14141 & 89.8 \\
\hline TOTAL & 2052 & 39723 & 95.0 \\
\hline
\end{tabular}


The downtime was all in the precleaning circuit unit operations. The hand 1 ing system accounted for $9.6 \%$ of the downtime. Start-up of the plant after shutdown accounted for $11.5 \%$ of downtime. The cagepactor accounted for $24.7 \%$ of the downtime. Pumping problems accounted for $46.1 \%$ of the downtime primarily because of oversize material generated by frozen coal when processing Illinois No. 6 . The total downtime attributed to the advanced circuit unit operations was zero. This availability compares very closely to industry standards, and it could have been improved in a commercial-size plant.

\section{RECOMMENDATIONS FOR FUTURE WORK}

Based on the above, future work should examine means of reconstituting this product into either pellets and/or briquettes and reducing the final surface moisture to less than $10 \%$. This will result in a product that would be compatible with existing material handling systems and have an as-received Btu of 12,000-12,500 Btu, which is much more marketable.

A second problem requiring future work was the size reduction of the precleaning circuit product. Several alternative grinding systems should be investigated to improve the economics of final grinding. The most viable alternative would be the application of a tower mill for producing the final grind. A tower mill has demonstrated the ability to require lower horsepower than tumbling ball mills. This would improve the economics of the operation of the commercial plant.

These are the main areas of future work, (1) improved handleability and as-received Btu characteristics of the final product, and (2) improved economical grinding. Both of these could be accomplished at bench-scale and then mathematically scaled up to commercial sizes. There are several manufacturers of tower mills and reconstitution equipment capable of performing laboratory-scale testing, then, based upon this data, scale up to commercial-size equipment.

At the beginning of this quarter, a Draft Task 14 was prepared and released for review and comments. The review and comments were returned to ICF Kaiser, and a rewrite was started at the end of this quarter incorporating the comments into a final document for publication. 


\subsection{TASK 15 FINAL SEMI-WORKS CONCEPTUAL DESIGN}

\subsection{Overview and Scope}

At the completion of this task, a conceptual design for a $20 \mathrm{TPH}$ semi-works facility will be available. The design will based on all knowledge gained previously in Tasks 5, 6, and 13. The work in this task will be primarily concerned with updating the conceptual design that was available in Task 8 with results of the POC scale-up operations from Task 13. Further, the team will project the design to a $200 \mathrm{TPH}$ commercial facility and provide a conceptual estimate of the capital and operating costs for that facility.

The task will include several deliverables - the final report, design drawings for the semi-works plant, a detailed capital cost estimate of the semi-works plant and a preliminary conceptual estimate for the commercial plant.

\subsection{Review of Work Completed This Quarter}

During this quarter, the engineering design drawings of the $20 \mathrm{TPH}$ Semi-Works plant were completed. Based on those drawings, a material take-off was completed. The material quantities, along with capital equipment pricing were utilized to develop a capital cost estimate. The capital cost estimate was completed for the 20 TPH Semi-Works preparation plant. This estimate is shown in Appendix A. The final capital cost was determined to be $\$ 10,915,352.00$.

The quarter was devoted to writing the Task 15 Report, and the draft report should be released during the next quarter for review. 


\subsection{TASK 16 POC MODULE REMOVAL}

\subsection{Overview and Scope}

This task involves removing the POC module from the host facility, restoring the site, and protecting and shipping all Contractorprocured government property to PETC.

In decommissioning the process equipment, strict adherence to removing process reagents and contaminants and to capping and blanking all openings on the POC module and OCDO host facility interfaces. A11 government property will be protected from environmental damage prior to and during shipment to PETC. All DOE and OCDO host facility property will be restored to its condition prior to the start of Task 11 .

\subsection{Review of Work Completed This Quarter}

During this quarter the DOE equipment was properly stored. A11 nuclear material was properly returned to the original suppliers, and all reagents were properly removed and disposed of as required by Federal, State and local regulations. The OCDO facility was restored and OCDO testing continued.

The DOE/PETC and OCDO reached a Persona7 Property Loan Agreement concerning the DOE equipment. This equipment will be used by OCDO in conducting future additional coal preparation research at the test site. 
APPENDIX A 


\section{EQUIPMENT LIST FOR SEMI-WORKS PLANT}


20 TPH CLEAN COAL SEMI-WORKS CONCEPTUAL DESIGN

1994cost.wk3 ICF KAISER ENGINEERS PROJECT NUMBER 88107-250-00

\begin{tabular}{|c|c|c|c|c|c|c|c|c|c|c|c|}
\hline \multicolumn{12}{|c|}{ TASK 15} \\
\hline $\begin{array}{c}\text { EQUIP. } \\
\text { NO. }\end{array}$ & DESCRIPTION & $\begin{array}{c}\text { \# OF } \\
\text { UNITS }\end{array}$ & WEIGHT & PRICE & $\begin{array}{c}\text { UNIT } \\
\text { HP }\end{array}$ & $\begin{array}{c}\text { TOTAL } \\
\mathrm{HP} \\
\end{array}$ & ENCL & VOLTS & RPM & $\begin{array}{c}\text { MOTOR } \\
\text { SUPPLIED }\end{array}$ & COMMENTS \\
\hline 100 & PLANT FEED CONVEYOA & - & - & $\overline{7} 070$ & - & - & - & - & - & - & BY OTHERS \\
\hline 105.1 & BELT MAGNET RECTIFIER & 1 & $\begin{array}{r}1.010 \\
210\end{array}$ & $\begin{array}{r}7,070 \\
\text { INCLUDED }\end{array}$ & - & - & - & - & - & - & $\begin{array}{l}\text { ERIEZ MODEL SE7235MCI } \\
\text { ERIEZ MODEL } 36 \mathrm{C} 1800 \text { WATTS }\end{array}$ \\
\hline 110 & RAW COAL CAUSHER & 1 & 12,000 & 87,739 & 50.00 & 50.00 & TEFC & 480 & 1800 & YES & GUNDLACH 45 DA \\
\hline 111 & RAW COAL CRUSHER & 1 & 12,000 & 87,739 & 50.00 & 50.00 & TEFC & 480 & 1800 & YES & GUNDLACH 45 DA \\
\hline 112 & RAW COAL SCAEEN & 1 & 5,000 & 13,498 & 7.50 & 7.50 & TEFC & 480 & 1800 & YES & TABOA $4 \times 12$ VIBPAT. INCLINED \\
\hline 113 & OVERSIZE BUCKET ELEVATOR & 1 & 15,000 & 13,498 & 10.00 & 10.00 & TEFC & 480 & 1800 & YES & GOODMAN \\
\hline 115 & RAW COAL FEED SUMP & 1 & - & - & - & - & - & - & - & - & SEE PLATEWORK \\
\hline 120 & RAW COAL FEED PUMP & 1 & 5,000 & 13,498 & 15.00 & 15.00 & TEFC & 480 & 1800 & YES & GOYNE PUMP \\
\hline 125 & DELETED & - & - & - & - & - & - & - & - & - & - \\
\hline 130 & DELETED & - & - & - & - & - & $=$ & $=$ & - & - & - \\
\hline 135 & REFUSE CENTRIFUGE DRIVE & 1 & 5,000 & 35,996 & 10.00 & 10.00 & TEFC & 480 & 1800 & YES & CMI HVC-20 \\
\hline 135.1 & REFUSE CENTIFUGE VIBRATOR & 1 & - & INCLUDED & 7.50 & 7.50 & TEFC & 480 & 1800 & YES & CMI HVC -20 \\
\hline 135.2 & REFUSE CENTIFUGE OIL PUMP & 1 & - & INCLUDED & 0.50 & 0.50 & TEFC & 480 & 1800 & YES & CMI HVC-20 \\
\hline 140 & DESLIME SIEVE BEND & 2 & 3,360 & 9,899 & - & - & - & - & - & - & $3^{\prime} W, 80^{\prime} R, 60, .35 \mathrm{MM}, 3 / 32$ ISO \\
\hline 145 & DESLIME SCREEN & 1 & 9,000 & 22,497 & 10.00 & 10.00 & TEFC & 480 & 1800 & YES & TABOR 4 XI2 SD VIB. HORIZ ONTAL \\
\hline 150 & MIDDLINGS CRUSHER DRIVE 1 & 1 & 12,000 & 105,737 & 100.00 & 100.00 & TEFC & 480 & 1800 & YES & GUNDLACH CAGEPACTOR \\
\hline 150.1 & MIDDLINGS CRUSHEADRIVE 2 & 1 & - & INCLUDED & 75.00 & 75.00 & TEFC & 480 & 1800 & YES & SAME \\
\hline 151 & OVERSIZE PAOTECTION SUMP & 1 & - & - & - & 0.00 & - & - & - & - & SEE PLATEWORK \\
\hline 152 & OVERSIZE PROTECTION PUMP & 1 & 5,000 & 13,498 & 40.00 & 40.00 & TEFC & 480 & 1800 & YES & GOYNE PUMP \\
\hline 153 & OVERSIZE PROTECTION SIEVE BEND & 2 & 5,600 & 16,493 & - & - & - & - & - & - & $5^{\prime} W, 40^{\prime} R, 60,35 \mathrm{MM}, 3 / 32$ ISO \\
\hline 155 & FINE HYDAO FEED SUMP & 1 & & - & - & - & - & - & - & - & SEE PLATEWORK \\
\hline 160 & FINE HYDAO FEED PUMP & 1 & 5,000 & 13,498 & 60.00 & 60.00 & TEFC & 480 & 1800 & YES & GOYNE PUMP \\
\hline 165 & FINE HYDAOCYCLONES & 5 & 15,600 & 41,125 & - & - & - & - & - & - & KAEBS $10^{\circ}$ DIAMETEA W/STANDD \\
\hline 170 & DELETED & _ & - & - & - & - & - & - & - & - & - \\
\hline 175 & DELETED & - & - & - & - & - & - & - & - & - & - \\
\hline 180 & DELETED & - & - & - & - & - & - & - & - & - & - \\
\hline 190 & DELETED & - & $\overline{-}$ & - & $\overline{-}$ & - & - & - & - & - & $=$ \\
\hline 190.1 & DELETED & - & - & - & - & - & - & - & - & - & - \\
\hline 200 & DELETED & - & - & - & - & - & - & - & - & - & - \\
\hline 200.1 & DELETED & _ & _ & - & - & _ & - & - & - & - & _ \\
\hline 202 & CLASSIFYING CYCLONE SUMP & 1 & - & - & - & - & - & - & - & - & SEE PLATEWORK \\
\hline 205 & CLASSIFYING CYCLONE PUMP & $i$ & 5,000 & 13,498 & 200.00 & 200.00 & TEFC & 480 & 1800 & YES & GOYNE PUMP \\
\hline 207 & CLASSIFYING CYCLONES & B & 17,640 & 42,992 & - & - & - & - & - & - & KREBS $10^{\circ}$ DIAMETER W/STAND \\
\hline 208 & VARI-SIEVE & 2 & 7500 & & - & - & - & - & - & - & KAEBS 5 'W VARI-SIEVE \\
\hline 210 & BALL MILL & 1 & 186,000 & 787,405 & 750.00 & 750.00 & TEFC & 4160 & 900 & YES & 10. DIA. X $6^{\prime}$ CONICAL BALL MILL \\
\hline
\end{tabular}


20 TPH CLEAN COAL SEMI-WORKS CONCEPTUAL DESIGN ICF KAISER ENGINEERS PAOJECT NUMBER 88107-250-00

1994cost.wk3

\begin{tabular}{|c|c|c|c|c|c|c|c|c|c|c|c|}
\hline \multicolumn{12}{|c|}{ TASK 15 EQUIPMENT LIST FOR 20 TONS PER HOUR, SEMI-WORKS FLOWSHEET } \\
\hline $\begin{array}{c}\text { EQUIP. } \\
\text { NO. }\end{array}$ & DESCRIPTION & \begin{tabular}{|c|} 
\# OF \\
UNITS
\end{tabular} & WEIGHT & PRICE & $\begin{array}{c}\text { UNIT } \\
\text { HP }\end{array}$ & $\begin{array}{c}\text { TOTAL } \\
\text { HP }\end{array}$ & ENCL & VOLTS & RPM & $\begin{array}{c}\text { MOTOR } \\
\text { SUPPLIED } \\
\end{array}$ & COMMENTS \\
\hline 215 & ADVANCED FLOTATION FEED SUMP & 1 & - & - & - & - & - & - & - & - & $\overline{\text { SEE PLATEWORK }}$ \\
\hline 220 & ADVANCED FLOTATION FEED PUMP & i) & 5,000 & 13,498 & 100.00 & 100.00 & TEFC & 480 & 1800 & YES & GOYNE PUMP \\
\hline 225 & FLOTATION FEED DISTAIBUTOR & 1 & 2500 & - & - & - & - & - & - & - & SEE PLATEWORK \\
\hline 230 & ADVANCED FLOTATION CELL & 4 & 46,000 & 224,973 & - & - & - & - & - & - & ICF KE MICROCEL ${ }^{\text {TM }}$ MODEL 12025 \\
\hline 230.1 & ADVANCED FLOTATION PUMP & 4 & 5,000 & INCLUDED & 75.00 & 300.00 & TEFC & 480 & 1800 & YES & GOYNE PUMP \\
\hline 240 & COAL STATIC THICKENER DRIVE & 1 & 17,000 & 78,740 & 3.00 & 3.00 & TEFC & 480 & 1800 & YES & EIMCO $50^{\circ}$ DIAMETER HIRATE \\
\hline 240.1 & COAL STATIC THICKENER LIFTING DEVICE & i. & - & INCLUDED & 1.00 & 1.00 & TEFC & 480 & 900 & YES & SAME \\
\hline 245 & COAL THICK. CLARIFIED WATER SUMP & 1 & & & - & - & - & - & - & - & SEE PLATEWORK \\
\hline 247 & COAL THICK. CLARIFIED WATER PUMP & 1 & 5,000 & 13,498 & 200.00 & 200.00 & TEFC & 480 & 1800 & YES & GOYNE PUMP \\
\hline 249 & COAL STATIC THICKENERU'FLOW PUMP & i) & 5,000 & 13,498 & 25.00 & 25.00 & TEFC & 480 & 1800 & YES & GOYNE PUMP \\
\hline 250 & DELETED & - & - & - & - & - & - & - & - & - & - \\
\hline 255 & LETED & - & - & - & - & - & - & - & - & - & - \\
\hline 255.1 & ED & - & - & - & - & - & - & - & - & - & - \\
\hline 260 & CLEAN COAL FILTER DRIVE & 1 & 122,000 & 708,664 & 10.00 & 10.00 & TEFC & 480 & 1800 & YES & ANDRITZ FUTHNER, INC. \\
\hline 260.1 & AGITATOR & 3 & - & INCLUDED & 1.50 & 4.50 & TEFC & 480 & 1800 & YES & SAME \\
\hline 260.2 & DISCHARGE GATES & 1 & - & INCLUDED & 30.00 & 30.00 & TEFC & 480 & 1800 & YES & SAME \\
\hline 260.3 & AIR COMPRESSOR & 1 & 8,000 & 13,498 & 200.00 & 200.00 & TEFC & 480 & 1800 & YES & AIRTEC \\
\hline 260.4 & FILTRATE PUMP & 1 & 5,000 & 13,498 & 5.00 & 5.00 & TEFC & 480 & 1800 & YES & GOYNE PUMP \\
\hline 260.5 & ICATOR & 1 & - & - & 1.00 & 1.00 & TEFC & 480 & 1800 & YES & ANDRITZ RUTHNER, INC. \\
\hline 260.6 & AUXILLARY AIR COMPRESSOR & 1 & 5,000 & 13,498 & 7.50 & 7.50 & TEFC & 480 & 1800 & YES & SAME \\
\hline 260.7 & INTERNAL CONVEYOR & $i$ & - & & 10.00 & 10.00 & TEFC & 480 & 1800 & YES & SAME \\
\hline 265 & CLEAN COAL BELT & - & - & - & - & - & - & - & - & - & BYOTHERS \\
\hline 275 & AEFUSE STATIC THICKENER DAIVE & 1 & 17,000 & 78,740 & 3.00 & 3.00 & TEFC & 480 & 1800 & YES & EIMCO 60' DIAMETER HIRAATE \\
\hline 275.1 & REF. STATIC THICKENER LIFTING DEVICE & 1 & - & INCLUDED & 1.00 & 1.00 & TEFC & 480 & 900 & YES & SAME \\
\hline 280 & DELETED & - & _ & - & - & - & - & - & - & - & - \\
\hline 285 & DELETED & - & - & - & - & - & - & - & - & - & - \\
\hline 290 & REF. STATIC THICKENEA U'FLOW PUMP & 1 & 5,000 & 13,498 & 30.00 & 30.00 & $\overline{\text { TEFC }}$ & 480 & 1800 & YES & GOYNE PUMP \\
\hline 310 & DELETED & - & - & - & - & - & - & - & - & - & - \\
\hline 310.1 & OELETED & - & - & - & - & - & - & - & - & - & - \\
\hline 310.2 & DELETED & - & - & - & - & - & - & - & - & - & - \\
\hline 310.3 & DELETED & $=$ & - & - & - & - & $=$ & - & - & - & - \\
\hline 315 & REFUSE CONVEYOR & - & _ & - & - & - & - & - & - & - & BY OTHERS \\
\hline 320 & HEAVY MEDIA CYCLONE SUMP & 1 & - & - & - & - & - & - & - & - & SEE PLATEWORK \\
\hline 325 & YCLONE PUMP & 1 & 5,000 & 13,498 & 75.00 & 75.00 & TEFC & 480 & 1800 & YES & GOYNE PUMP \\
\hline 330 & HEAVY MEDIA CYCLONE & 1 & 1,350 & 10,911 & - & - & - & - & - & - & KAEBS $20^{\circ}$ DIAMETER CEĀĀMIC \\
\hline 335 & MIDS SIEVE BEND & 1) & 2,200 & 4,837 & - & - & - & - & - & - & $3^{\prime} W, 80^{\circ} R, 60,5 M M, 3 / 32$ ISO \\
\hline 340 & MIDS DRAIN \& RINSE SCREEN & i) & 18,000 & 44,995 & 20.00 & 20.00 & TEFC & 480 & 1800 & YES & TABOR $4 \times 16$ SD VIB. HORIZONTAL \\
\hline 345 & REFUSE SIEVE BEND & 1 & 2,800 & 8,324 & - & - & - & - & - & - & $3^{\prime} W, 40^{\prime} \mathrm{A}, 60,5 \mathrm{MM}, 3 / 32$ ISO \\
\hline
\end{tabular}


1994cost.wk3

\begin{tabular}{|c|c|c|c|c|c|c|c|c|c|c|c|}
\hline \multicolumn{12}{|c|}{ TASK 15 EQUIPMENT LIST FOR 20 TONS PER HOUA, SEMI-WOAKS FLOWSHEET } \\
\hline $\begin{array}{l}\text { EQUIP. } \\
\text { NO. }\end{array}$ & DESCRIPTION & $\begin{array}{l}\text { \# OF } \\
\text { UNITS }\end{array}$ & WEIGHT & PRICE & $\underset{\mathrm{HP}}{\mathrm{UNIT}}$ & $\begin{array}{c}\text { TOTAL } \\
\text { HP }\end{array}$ & ENCL & VOLTS & RPM & $\begin{array}{c}\text { MOTOA } \\
\text { SUPPLIED }\end{array}$ & COMMENTS \\
\hline 350 & REFUSE DRAIN \& AINSE SCAEEN & 1 & 12,000 & 28,122 & 15.00 & 15.00 & TEFC & 480 & 1800 & YES & TABOR 4 X16 SD VIB. HOAIZONTAL \\
\hline 355 & DELETED & 1 & & & - & - & - & - & - & - & - \\
\hline 360 & HEAVY MEDIA CONTROL BOX & 1 & - & & - & - & - & - & - & - & SEE PLATEWORK \\
\hline 365 & HEAVY MEDIA SENSOA BOX & 1 & - & $=$ & - & - & - & - & $\overline{-}$ & $\overline{-}$ & SEE PLATEWORK \\
\hline 370 & DILUTE MEDIA SUMP & 1 & - & - & - & - & - & - & - & - & SEE PLATEWORK \\
\hline 375 & DILUTE MEDIA PUMP & 1 & 5,000 & 13,498 & 10.00 & 10.00 & TEFC & 480 & 1800 & YES & GOYNE PUMP \\
\hline 380 & MAGNETIC SEPARATOR & 1 & 4,700 & 18,673 & 5.00 & 5.00 & TEFC & 480 & 1800 & YES & ERIEZ 36" DIAMETER X 9'W \\
\hline 390 & MAGNETITE ROTARY VALVE & $i$ & 1,000 & 5,624 & 5.00 & 5.00 & TEFC & 480 & 1800 & YES & ANDRITZ SPROUT-BAUER \\
\hline 395 & INSTRUMENT AIR COMPAESSOR & 1. & 2,000 & 5,624 & 25.00 & 25.00 & TEFC & 480 & 1800 & YES & AIRTEC \\
\hline 395.1 & INSTRUMENT AIR DRYER & it & 500 & 1,687 & 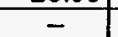 & 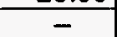 & $\theta \cdot$ & 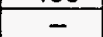 & 0 & $=$ & SAME \\
\hline 395.2 & PREFILTERS & i) & 500 & 1,687 & 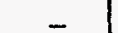 & - & 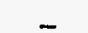 & - & _ & - & SAME \\
\hline 395.3 & AFTER FILTERS & 2 & 750 & 2,812 & - & - & - & - & - & - & SAME \\
\hline 398 & PLANT \& COLUMN AIR COMPRESSOR & 1 & 8000 & 2,812 & 200.00 & 200.00 & TEFC & 480 & 1800 & YES & AIRTEC \\
\hline 398.1 & PREFILTERS & 1 & 500 & 2,812 & - & - & . & - & - & - & SAME \\
\hline 398.2 & AFTER FILTERS & 2 & 750 & 2,812 & - & - & - & - & - & - & SAME \\
\hline 400.6 & CATIONIC HOLDING TANK & 1 & 1,000 & INCLUDED & - & . & (1) & - & - & - & SAME \\
\hline 400.7 & CATIONIC METERING PUMP & 2 & 1,800 & 6,749 & 0.25 & 0.50 & TEFC & 110 & 1800 & YES & SAME \\
\hline 400.8 & SETTLING RATE DETECTOR & 2 & 2,000 & 22,497 & - & - & - & 110 & - & - & SAME \\
\hline 400.9 & WATER CLARITY MEASURMENT & 2 & 1,800 & 8,999 & - & - & - & 110 & - & $=$ & SAME \\
\hline 400.10 & PH REAGENT PUMP & 1 & 3000 & 7,424 & 0.50 & 0.50 & TEFC & 110 & 1800 & YES & SAME \\
\hline 405 & REAGENT SYSTEM & 1 & & & - & - & - & - & - & - & SAME \\
\hline 405.1 & FROTHER BULK STORAGE & 1 & 5,000 & 5,624 & - & - & - & - & - & - & SAME \\
\hline 405.2 & FROTHER TRANSFER PUMP & 1) & 500 & 6,749 & 10.00 & 10.00 & TEFC & 480 & 1800 & YES & SAME \\
\hline 405.3 & FROTHER DAY TANK & 1 & & & & & & - & & & SAME \\
\hline 405.4 & FROTHER REAGENT PUMPS & 4 & 1,500 & 10,124 & 0.25 & 1.00 & TEFC & 110 & 1800 & YES & SAME \\
\hline 405.5 & COLLECTOR BULK STORAGE & 1 & 5,000 & 5,624 & & & & - & & & SAME \\
\hline 405.6 & COLLECTOR TRANSFER PUMP & 1 & 500 & 6,749 & 10.00 & 10.00 & TEFC & 480 & 1800 & YES & SAME \\
\hline
\end{tabular}




\section{UNIT LIST}

20 TPH CLEAN COAL SEMI-WORKS CONCEPTUAL DESIGN ICF KAISER ENGINEERS PROJECT NUMBER 8B107-250-00

1994cost.wk3

\begin{tabular}{|c|c|c|c|c|c|c|c|c|c|c|c|}
\hline \multicolumn{12}{|c|}{ TASK 15} \\
\hline $\begin{array}{c}\text { EQUIP. } \\
\text { NO. }\end{array}$ & DESCAIPTION & \begin{tabular}{|c|} 
\# OF \\
UNITS
\end{tabular} & WEIGHT & PRICE & $\begin{array}{c}\text { UNIT } \\
\text { HP }\end{array}$ & $\begin{array}{c}\text { TOTAL } \\
\text { HP }\end{array}$ & ENCL & VOLTS & RPM & $\begin{array}{c}\text { MOTOR } \\
\text { SUPPLIED }\end{array}$ & COMMENTS \\
\hline 405.7 & COLLECTOR DAY TANK & 1 & - & - & $=$ & - & - & - & - & - & SAME \\
\hline 405.8 & COLLECTOR REAGENT FEEDERS & 4 & 1,500 & 10,124 & 0.25 & 1.00 & TEFC & 110 & 1800 & YES & SAME \\
\hline 405.9 & DELETED & - & - & - & - & - & - & - & - & - & - \\
\hline 410 & OVERDENSE MEDIA SUMP & 1 & - & - & - & 0.00 & - & - & - & - & SEE PLATEWORK \\
\hline 415 & OVERDENSE MEDIA PUMP & 1 & 5,000 & 13,498 & 10.00 & 10.00 & TEFC & 480 & 1800 & YES & GOYNE PUMP \\
\hline 420 & OVERDENSE MEDIA CONTROL BOX & 1 & - & - & - & - & - & - & - & - & SEE PLATEWORK \\
\hline 425 & OVERDENSE MEDIA SENSOR BOX & 1 & - & - & - & - & - & - & - & - & SEE PLATEWORK \\
\hline 430 & BALL MILL OVERHEAD CAANE HOIST & 1 & 5,000 & 28,122 & 25.00 & 25.00 & TEFC & 480 & 1800 & YES & THEAN \\
\hline 430.1 & BALL MILL OVEAHEAD CAANE TRAM & 1 & - & INCLUDED & 10.00 & 10.00 & TEFC & 480 & 1800 & YES & THEAN \\
\hline 435 & DELETED & - & - & - & - & - & - & - & - & - & - \\
\hline 435.1 & DELETED & - & - & - & - & - & - & - & - & - & - \\
\hline 440 & DELETED & - & - & - & - & - & - & - & - & - & - \\
\hline 440.1 & DELETED & - & - & - & - & - & - & - & - & $=$ & $=$ \\
\hline 445 & DOORS & - & - & - & - & - & - & - & - & - & - \\
\hline 445.1 & MAN DOORS & & - & 5,624 & - & - & - & - & - & - & SEE TAKE OFFS \\
\hline 445.2 & MACHINERY DOORS & & - & 6,749 & - & - & - & - & $=$ & - & SEE TAKE OFFS \\
\hline 450 & PIPING & - & & 281,216 & - & - & - & - & - & - & SEE TAKE OFF $\bar{S}$ \\
\hline 455 & CONCRETE & - & - & 0 & - & - & - & - & - & _ & SEE TAKE OFFS \\
\hline 455.1 & FOUNDATIONS AND GROUND FLOOR & - & CU YD & 0 & - & - & $\overline{-}$ & $=$ & $\overline{-}$ & $\bar{z}$ & LABOR-350/YD MAT'L-150/YD \\
\hline 455.2 & ELEVATEO FLOORS & - & CU YD & 0 & - & - & - & - & - & 二 & SAME \\
\hline 455.3 & STATIC THICKENER TANK & $=$ & $\mathrm{CUYD}$ & 0 & - & - & - & - & - & - & SAME \\
\hline 455.4 & COAL STATIC THICKENER TANK & - & CU YD & 0 & - & - & - & - & - & - & SAME \\
\hline 460 & STRUCTURAL STEEL & - & & 0 & - & - & - & - & - & - & \\
\hline 465 & MILD STEEL PLATEWORK & - & & 의 & - & - & - & - & $=$ & - & \\
\hline 470 & A. R. STEEL PLATEWORK & - & & 0 & - & - & - & - & - & - & \\
\hline 475 & OTHER LINERS & - & & 0 & - & - & - & - & - & - & \\
\hline 480 & ROOFING AND SIDING & - & - & o & - & - & - & - & - & - & \\
\hline 480.1 & INSULATED SIDING & - & sos & 0 & $=$ & - & - & $=$ & - & - & \\
\hline 480.2 & INSULATED ROOFING & - & SAS & $\mathbf{0}$ & $=$ & - & - & $\overline{-}$ & $\overline{-}$ & - & \\
\hline 485 & CLEAN-UP PUMP & 1 & 5,000 & 13,498 & 7.50 & 7.50 & TEFC & 480 & 1800 & YES & GOYNE PUMP \\
\hline 495 & GLAND WATER PUMP & 1 & 2,500 & 2,500 & 5.00 & 5.00 & TEFC & 480 & 1800 & YES & GOYNE PUMP \\
\hline 500 & INSTRUMENTS & - & & - & - & - & - & - & - & - & \\
\hline 500.1 & SLURRY SAMPLERS & 3 & $\mathbf{7}, 000$ & 94,489 & 5.00 & 15.00 & TEFC & 480 & 1800 & YES & ESTIMATED \\
\hline 500.2 & DRY SAMPLERS & 2 & 5,250 & 20,248 & 5.00 & 10.00 & TEFC & 480 & 1800 & YES & ESTIMATED \\
\hline 500.3 & PRESSURE TRANSMITTERS & 3 & - & - & - & - & - & - & - & - & ROSEMOUNT \\
\hline 500.4 & VARIBLE FREQUENCY DRIVE & 1 & - & - & - & - & - & - & - & - & WOODS \\
\hline 500.5 & WEIGH TRANSMITTER & 1 & - & - & $=$ & = & - & - & - & - & MILLTRONICS \\
\hline
\end{tabular}


UNIT LIST

20 TPH CLEAN COAL SEMI-WOAKS CONCEPTUAL DESIGN ICF KAISER ENGINEERS PROJECT NUMBER 88107-250-00

1994cost.wk3

\begin{tabular}{|c|c|c|c|c|c|c|c|c|c|c|c|}
\hline \multicolumn{12}{|c|}{ TASK 15} \\
\hline $\begin{array}{c}\text { EQUIP. } \\
\text { NO. }\end{array}$ & DESCRIPTION & \begin{tabular}{|c|} 
\# OFF \\
UNITS
\end{tabular} & WEIGHT & PRICE & $\begin{array}{l}\text { UNIT } \\
\text { HP }\end{array}$ & $\begin{array}{c}\text { TOTAL } \\
\text { HP }\end{array}$ & ENCL & VOLTS & RPM & $\begin{array}{c}\text { MOTOA } \\
\text { SUPPLIED }\end{array}$ & COMMENTS \\
\hline 500.6 & NUCLEARDENSITY GAUGES & 3 & 2,500 & 36,558 & - & - & - & - & - & $\overline{-}$ & ROSEMOUNT \\
\hline 500.7 & MAGNETIC FLOWMETERS & 1 & 300 & 33,746 & - & - & - & - & - & - & ROSEMOUNT \\
\hline 500.8 & AMP TRANSMITTERS & 22 & 1,500 & 40,495 & - & - & - & - & - & - & KATY \\
\hline 500.9 & I/P CONVERTERS & 9 & - & - & - & - & - & - & - & - & FOXBORO \\
\hline 500.10 & Dp CELLS & 9 & 300 & 20,248 & - & $=$ & - & - & $=$ & - & FOXBORO \\
\hline 500.11 & CONTROL VALVES & 9 & 1,000 & 13,498 & - & - & - & - & - & - & FOXBORO \\
\hline 500.12 & DELETED & - & & & - & - & - & - & - & - & - \\
\hline 500.13 & AUTOMATIC FLOC MIXING SYSTEM & 1 & 2,000 & 22,497 & 1.50 & 1.50 & TEFC & 480 & 1800 & YES & ESTIMATED \\
\hline 500.14 & pH METERS & 2 & 150 & 10,124 & - & - & - & - & - & - & ESTIMATED \\
\hline 500.15 & SUMP LEVEL CONTROLS & 10 & 1,500 & 28,122 & - & - & - & - & - & - & ESTIMATED \\
\hline 500.16 & HEAVY MEDIA LEVEL CONTROLS & 2 & 500 & 14,623 & - & - & - & - & - & - & ESTIMATED \\
\hline$\overline{E F-1}$ & EXHAUST FANS & 1 & & & 0.5 & 0.50 & TEFC & 120 & 1800 & YES & GAEENHECK MODEL BCF $-1 \overline{0}$ \\
\hline$E F-2$ & EXHAUST FANS & 1 & & & 3 & 3.00 & TEFC & 480 & 1800 & YES & GREENHECK MODEL SPNE - 36 \\
\hline EF -3 & EXHAUST FANS & 1 & & & 5 & 5.00 & TEFC & 480 & 1800 & YES & GREENHECK MODEL SPNE - 42 \\
\hline$\overline{E F}-4$ & EXHAUST FANS & 1 & & & 1 & 1.00 & TEFC & 480 & 1800 & YES & GREENHECK MODEL SPNE - 36 \\
\hline$E F-5$ & EXHAUST FANS & 1 & & & 3 & 3.00 & TEFC & 480 & 1800 & YES & GREENHECK MODEL SPNE - 36 \\
\hline$E F-6$ & EXHAUST FANS & 1 & & & 0.75 & 0.75 & TEFC & 480 & 1800 & YES & GREENHECK MODEL SPNE - 30 \\
\hline$A C-1$ & AIR CONDITIONER FAN & 1 & & & 0.33 & 0.33 & TEF & 480 & 1800 & YES & CORAECT AIR CORP. MODEL SC2 4 \\
\hline$A C-1.1$ & AIR CONDITIONER COMPAESSOR & 1 & & & 5 & 5.00 & TEFC & 480 & 1800 & YES & CORRECT AIR CORP. MODEL SC24 \\
\hline$A C-1.2$ & AIR CONDITIONER STRIP HEATER & 1 & & & $3 \mathrm{~kW}$ & 0.00 & TEFC & 480 & 1800 & YES & CORRECT AIR CORP. MODEL SC24 \\
\hline$A C-2$ & AIR CONDITIONER FAN & 1 & & & 0.33 & 0.33 & TEFC & 480 & 1800 & YES & ADDISON MODEL PCO44 \\
\hline$A C-2.1$ & AIR CONDITIONER COMPAESSOR & 1 & & & & 5.00 & TEFC & 480 & 1800 & YES & ADDISON MODEL PC044 \\
\hline$A C-2.2$ & AIR CONDITIONER STRIP HEATER & 1 & & & $9 \mathrm{~kW}$ & 0.00 & TEFC & 480 & 1800 & YES & ADDISON MODEL PCO44 \\
\hline$A C-3$ & AIR CONDITIONER FAN & 1 & & & 0.33 & 0.33 & TEFC & 480 & 1800 & YES & ADDISON MODEL PCO44 \\
\hline$A C-3.1$ & AIR CONDITIONER COMPRESSOR & 1 & & & 7.5 & 7.50 & TEFC & 480 & 1800 & YES & ADDISON MODEL PC044 \\
\hline$A C-3.2$ & AIR CONDITIONER STRIP HEATER & 1 & & & $18 \mathrm{~kW}$ & 0.00 & TEFC & 480 & 1800 & YES & ADDISON MODEL PCO44 \\
\hline$H V-1$ & HEATING \& VENTILATING UNIT FAN & 1 & & & & 5.00 & TEFC & 480 & 1800 & YES & BAOD \& MCCLUNG MODEL CAP -22 \\
\hline$H V-1.1$ & HEATING \& VENTILATING UNIT HEATER & 1 & & & $16 \mathrm{KW}$ & 0.00 & TEFC & 480 & 1800 & YES & BROD \& MCCLUNG MODEL CAP - 22 \\
\hline$H V-2$ & HEATING \& VENTILATING UNIT FAN & 1 & & & & 2.00 & TEFC & 480 & 1800 & YES & BROD \& MCCLUNG MODEL CAP-12 \\
\hline$H V-2.1$ & HEATING \& VENTILATING UNIT HEATER & 1. & & & $34 \mathrm{~kW}$ & 0.00 & TEFC & 480 & 1800 & YES & BROD \& MCCLUNG MODEL CAP - 12 \\
\hline $\mathrm{UH}-1$ & UNIT HEATER A - G & 7 & & & $10 \mathrm{KW}$ & 0.00 & TEFC & 480 & 1800 & YES & Q-MARK MODEL MUH-10-4 \\
\hline $\mathrm{UH}-2$ & UNIT HEATER A - U & 21 & & & $15 \mathrm{KW}$ & 0.00 & TEFC & 480 & 1800 & YES & Q-MARK MODEL MUH-15-4 \\
\hline UH-3 & UNIT HEATER A - N & 14 & & & $20 \mathrm{KW}$ & 0.00 & TEFC & 480 & 1800 & YES & Q-MARK MODEL MUH - 20-4 \\
\hline $\mathrm{LV}-1$ & LOUVEAS $A-x$ & 24 & & & - & - & - & - & - & - & AM WARM \& VENT MOD. LF - $31 \bar{A}-\bar{A}$ \\
\hline PRD-1 & PRESSURE RELIEF DAMPER & 1 & & & - & - & - & - & - & - & AM WARM \& VENT MOD. PR-10 \\
\hline
\end{tabular}

\begin{tabular}{|c|c|c|c|c|c|c|c|c|c|c|}
\hline & TOTAL VALUES & & $\mathbf{7 1 0 , 1 7 5}$ & $\mathbf{3 , 4 8 4 , 7 7 2}$ & & 2,822 & & & \\
\hline
\end{tabular} 


\section{DETAILED CAPITAL COST ESTIMATE}




\author{
ESTIMATE CRITERIA \\ FOR \\ ENGINEERING DEVELOPMENT OF \\ ADVANCE PHYSICAL FINE COAL \\ CLEANING TECHNOLOGIES - FROTH FLOTATION \\ PREPARED FOR \\ U.S. DEPARTMENT OF ENERGY \\ PITTSBURGH ENERGY TECHNOLOGY CENTER \\ PITTSBURGH, PA. \\ TYPE 3 PRELIMINARY COST ESTIMATE \\ PREPARED BY \\ ICF KAISER ENGINEERS. INTERNATIONAL \\ PITTSBURGH, PA
}

\title{
SCOPE OF WORK
}

The Department of Energy has commissioned ICF Kaiser Engineers International to develop generic facility for the cleaning of fine coal using the advance froth floatation technology. The facility is based on processing +1.5 tons of raw coal per hour.

\section{PURPOSE}

Provide a preliminary cost estimate for a generic advance froth flotation coal cleaning facility based on the plant being located in the Greater Pittsburgh Area. This plant could be built anywhere within the United States.

\section{DRAWINGS AND SPECIFICATIONS}

The specifications and drawings were prepared by ICF KE. The specifications and drawings are based on the test results from the labaratory and proof-of concept plant.

\section{ESTIMATE FORMAT}

The estimate utilizes ICF KE's interactive estimating system(IEST) and is formatted to show quantities, manhours, labor cost. construction equipment usage, material and equipment, subcontracts, indirect costs, contractor's overhead and protit, and total dollars for each cost element.

The estimate is an ICF KE Type 3, Preliminary Estimate as defined by the attached estimate type sheets.

\section{QUANTITIES}

Quantities for the estimate were developed from the drawings provided and estimators judgement.

DOE 


\section{SILETIX}

Sales tax has been excluded.

\section{COST EXCLUSIONS}

Permits and Licenses

Finance Charges

Owner's Cost

Land and Right of Way

Soil Investigation

Environmental Reports

Legal Services

Utilities

\section{CONTINGENCY}

The estimate contains contingency at $5 \%$ to provide for unioreseen events which statistically are bound to occur during the life of the project.

\section{ESCALATION}

Escalation has been excluded.

\section{ESTIMATE DISCUSSION}

The project was commissioned by the Department Of Energy to determine the feasibility of cleaning coal by the advance froth flotation process. A preliminary cost estimates was prepared with no specify site selected. Estimate cost were based on the plant being constructed in the Greater Pittsburgh Area. 
ICF KAISER ENGINEERS, INC.

DEPARTMENT OF ENERGY

JOB HO. 88107-250-00
ICF KAISER ENGINEERS INTERACTIVE ESTIMATING

20 IPH CIEAN COAL SEMI-WORKS CONCEPTUAL DESIGN GENERAL ESIIMATE FOR REFERANCE

REPORT S1 - ESIIMATE SUMMARY BY FACIIIIY
PAGE 1

DAIE : $07 / 13 / 94 \quad 16: 0$

\section{WORK BREAKDWN}

FACIL.STANDRD DESCRIPTION

\section{0}

200
300
400

500

675

675

700

9001

901

903

904

\section{CONCRETE AND FOUNDATIONS}

STRUCTURAL SIEEL

ARCHIIECTURAL WORK

EQUIPMENT INSIALLAIION

$$
\text { PIPING }
$$

MECHANICAL

ELECTRICAL AND INSTRUMENTATION

INDIRECTS AND DISIRIBUTABLES

ENGINEERING

PROJECI/CONSIRUCTION MANAGEMENT

FIELD OFFICE EXPENSES

INSURANCE / TAXES/PERMIIS/

REPORT TOTAL

ICFKE PROFIT/FEE D $5 \%$

SUBTOIAL

PROJECT CONIINGENCY a $5 \%$

GRAND TOIAL

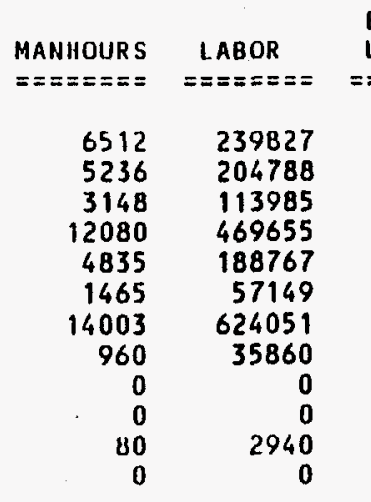

48,319

$1,937,022$
EQUIP USAGE MAT MA TER IAL

EQUIP MEN T

\section{$24678 \quad 141066$}

$29719 \quad 489556$

$3126 \quad 187882$

$98705 \quad 187620$

$25478 \quad 157284$

$5449-14325$

38033234657

0

372

57452

0
33496

173840

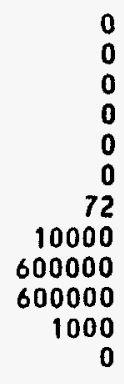

388737
10075
68742

229.765

$1,677,178$

$1,211.072$

$4.675,561$

$169,9 \div 8$

$9.900,5 \% 0$

495,021

$10,395,573$

519,714

$10,915,352$ 
ICF KAISER ENGINEERS, INC. DEPARTMENT OF ENERGY JOB NO. 88107-250-00
ICF KAISER ENGIHEERS INIERACIIVE ESIIMATING 20 IPII CIEAN COAL SEMI-WORKS CONCEPTUAL DESIGN GENERAL ESTIMAIE FOR REFERANCE
PAGE 1

DAIE: 07/13/46 13:27 BY

\begin{tabular}{|c|c|c|c|c|c|c|c|c|c|c|c|c|}
\hline \multicolumn{2}{|c|}{$\begin{array}{l}\text {-WORK BREAKDOWN-... } \\
\text { FACIL.STANDRD. WKPKG } \\
================\end{array}$} & $==+$ DESCR IPI ION & $\begin{array}{l}\text { QUANIIII } \\
== \pm===\end{array}$ & & $\begin{array}{l}\text { MANHOURS } \\
======\end{array}$ & $\begin{array}{c}\text { LABOR } \\
=======\end{array}$ & $\begin{array}{l}\text { EQUIP } \\
\text { USAGE } \\
=:=====\end{array}$ & $\begin{array}{l}\text { MAIERIAL } \\
=== \pm===\end{array}$ & $\begin{array}{l}\text { SUB- } \\
\text { CONIRACT } \\
=======\end{array}$ & $\begin{array}{l}\text { EQUIP- } \\
\text { MENI } \\
=======\end{array}$ & $\begin{array}{c}S / C \\
0 H \& P \\
=======\end{array}$ & $\begin{array}{c}\text { IOIAL } \\
\text { DOLLARS } \\
=======-\end{array}$ \\
\hline 200 & & CONCRETE AND FOUNDAIIONS & & & & & & & & & & \\
\hline 200 & .131102 & $\begin{array}{l}\text { EXCAVAIION MASS- } 1.5 C Y \text { BACKHOE } \\
\text { BUILDING FOUNDAIION }\end{array}$ & 880 & CY & 29 & 1060 & 339 & 0 & 0 & 0 & 34 & 1633 \\
\hline 200 & .1311021 & $\begin{array}{l}\text { EXCAVATION MASS - } 1.5 \text { CY BACKHOE } \\
\text { EQUIPMENT FOUNDAIIONS }\end{array}$ & 651 & Cy & 2 & 73 & 25 & 0 & 0 & 0 & 3 & 111 \\
\hline 200 & .134910 & $\begin{array}{l}\text { DISPOSAL - } 10 \text { MI ROUND IRIP } \\
10-12 \text { CY IRUCK } \\
\text { BUILOING FOUNDATION }\end{array}$ & 880 & $\mathrm{cy}$ & 80 & 3106 & 1741 & 0 & 0 & 0 & 174 & $50<1$ \\
\hline 200 & .1349101 & $\begin{array}{l}\text { DISPOSAL - } 10 \text { MI ROUND TRIP } \\
10-12 \text { CY IRUCK } \\
\text { EOUIPMENI FOUNDATION }\end{array}$ & 65 & $\mathrm{CY}$ & 6 & 233 & 129 & 0 & 0 & 0 & 13 & 375 \\
\hline 200 & .1349102 & $\begin{array}{l}\text { DISPOSAL - } 10 \text { MI ROUND IRIP } \\
10-12 \text { CY TRUCK } \\
50 \cdot \text { CLEAN COAL IHICKENER }\end{array}$ & 58 & cy & 5 & 194 & 113 & 0 & 0 & 0 & 11 & 318 \\
\hline 200 & .141100 & $\begin{array}{l}\text { EXCAVATION STRUCI. FOR MAT } \\
50^{\circ} \text { CLEAN COAL IHICKENER }\end{array}$ & $9 b$ & cy & 4 & 143 & 139 & 0 & 0 & 0 & 14 & 240 \\
\hline 200 & .1411001 & $\begin{array}{l}\text { EXCAVATION STRUCT. FOR MAT } \\
\text { 55' REFUSE THICKENER }\end{array}$ & 114 & $\mathrm{Cr}$ & 5 & 179 & 167 & 0 & 0 & 0 & 17 & ses \\
\hline 200 & .142210 & $\begin{array}{l}\text { BACKFILL SIRUCIURAL AGGREGAIE } \\
50^{\prime} \text { CLEAN COAL THICKENER }\end{array}$ & 380 & $\mathrm{cr}$ & 8 & 290 & 40 & 367 & 0 & 0 & 41 & 138 \\
\hline 200 & .1422101. & $\begin{array}{l}\text { BACKFILL STRUCTURAL AGGREGAIE } \\
\text { EQUIPMENT FOUNDAIIONS }\end{array}$ & $13 c$ & $\mathrm{cr}$ & 3 & 109 & 14 & 125 & 0 & 0 & 14 & 202 \\
\hline 200 & .1422102 & $\begin{array}{l}\text { BACKFILL SIRUCTURAL AGGREGAIE } \\
\text { OFFICE AREA }\end{array}$ & 350 & $\mathrm{Cr}$ & 7 & 253 & 37 & 338 & 0 & 0 & 38 & 600 \\
\hline 200 & .1422103 & $\begin{array}{l}\text { BACKFILL STRUCIURAL AGGREGATE } \\
55 \text {, REFUSE THICKENER }\end{array}$ & 46 & $\mathrm{CY}$ & 9 & 326 & 48 & 444 & 0 & 0 & 49 & 867 \\
\hline 200 & .142212 & $\begin{array}{l}\text { BACKFILL STRUCTURAL AGGREGATE } \\
\text { BUILDING FOUNDATION }\end{array}$ & 228 & c.y & 46 & 1665 & 238 & 2199 & 0 & 0 & 244 & 4340 \\
\hline $\begin{array}{l}200 \\
200\end{array}$ & $\begin{array}{l}.211000 \\
.212300\end{array}$ & $\begin{array}{l}\text { FORMS - BUILDING FOUNDAIION } \\
\text { REBAR-CONTINUOUS FOOTINGS } \\
\text { BUILDING FOUNDATION }\end{array}$ & $\begin{array}{r}2500 \\
87500\end{array}$ & $\begin{array}{l}S F \\
\text { LB }\end{array}$ & $\begin{array}{l}500 \\
875\end{array}$ & $\begin{array}{l}17043 \\
34322\end{array}$ & $\begin{array}{r}308 \\
5203\end{array}$ & $\begin{array}{r}1961 \\
20405\end{array}$ & $\begin{array}{l}0 \\
0\end{array}$ & $\begin{array}{l}\mathbf{0} \\
\mathbf{0}\end{array}$ & $\begin{array}{r}227 \\
2561\end{array}$ & $\begin{array}{l}19534 \\
62491\end{array}$ \\
\hline $\begin{array}{l}200 \\
200\end{array}$ & $\begin{array}{l}.213000 \\
.214100\end{array}$ & $\begin{array}{l}\text { EMBEDDED METALS-BLOG FONS } \\
\text { CONCRETE-FOOTINGS \& PEDESTALS } \\
3000 \text { PSI } \\
\text { BUILDING FOUNOATION }\end{array}$ & $\begin{aligned} 1400 \mathrm{~L} \\
700 \mathrm{C}\end{aligned}$ & $\begin{array}{l}\operatorname{LB} \\
\mathrm{Cr}\end{array}$ & $\begin{array}{r}85 \\
862\end{array}$ & $\begin{array}{r}3025 \\
31322\end{array}$ & $\begin{array}{r}0 \\
5240\end{array}$ & $\begin{array}{r}2226 \\
37842\end{array}$ & $\begin{array}{l}0 \\
0\end{array}$ & $\begin{array}{l}0 \\
0\end{array}$ & $\begin{array}{r}223 \\
4308\end{array}$ & $\begin{array}{r}5474 \\
78712\end{array}$ \\
\hline 200 & .220000 & $\begin{array}{l}\text { COLUMH CONCRETE } \\
\text { OFF ICE AREA }\end{array}$ & 220 & cr & 220 & 8084 & 1023 & 2665 & 0 & 0 & 369 & 121.1 \\
\hline $\begin{array}{l}200 \\
200\end{array}$ & $\begin{array}{l}.221000 \\
.221400\end{array}$ & $\begin{array}{l}\text { FORMS-EQUIP FOUNDATIONS } \\
\text { FORMS-RING FOUNDATIONS } \\
\text { 50' CLEAN COAL THICKENER }\end{array}$ & $\begin{array}{r}340 s \\
4200\end{array}$ & $\begin{array}{l}\text { SF } \\
\text { SF }\end{array}$ & $\begin{array}{r}89 \\
788\end{array}$ & $\begin{array}{r}3034 \\
30250\end{array}$ & $\begin{array}{r}55 \\
486\end{array}$ & $\begin{array}{r}551 \\
6455\end{array}$ & $\begin{array}{l}0 \\
0\end{array}$ & $\begin{array}{l}0 \\
0\end{array}$ & $\begin{array}{r}61 \\
694\end{array}$ & $\begin{array}{r}3701 \\
37885\end{array}$ \\
\hline 200 & .221405 & $\begin{array}{l}\text { FORMS-RING FOUNDATIONS } \\
551 \text { REFUSE THICKENER }\end{array}$ & $4600 \mathrm{~s}$ & $S F$ & 863 & 33129 & 532 & 7070 & 0 & 0 & 760 & 41491 \\
\hline $\begin{array}{l}200 \\
200\end{array}$ & $\begin{array}{l}.221500 \\
.222000\end{array}$ & $\begin{array}{l}\text { FORMS-SMALL PIERS } \\
\text { REBAR-EOUIP FOUNDATIONS }\end{array}$ & $\begin{array}{r}805 \\
6500 \mathrm{~L}\end{array}$ & $\begin{array}{l}S F \\
L B\end{array}$ & $\begin{array}{r}193 \\
55\end{array}$ & $\begin{array}{l}6579 \\
2229\end{array}$ & $\begin{array}{l}119 \\
325\end{array}$ & $\begin{array}{l}1152 \\
1516\end{array}$ & $\begin{array}{l}0 \\
0\end{array}$ & $\begin{array}{l}0 \\
0\end{array}$ & $\begin{array}{l}127 \\
184\end{array}$ & $\begin{array}{l}7977 \\
4254\end{array}$ \\
\hline
\end{tabular}


ICF KAISER ENGINEERS, INC. DEPARTMENT OF ENERGY JOB NO. B8107-250-00
ICF KAISER ENGINEERS INIERACIIVE ESIIMAIING 20 IPH CLEAN COAL SEMI-WORKS CONCEPIUAL DESIGN GENERAL ESTIMATE FOR REFERANCE

REPORT DI - ESTIMAIE DETAIL BY FACILITY
PAGE 2

DATE : $07 / 13 / 9413: 2$ BY

\begin{tabular}{|c|c|c|c|c|c|c|c|c|c|c|c|c|}
\hline \multicolumn{2}{|c|}{$\begin{array}{l}\text { - WORK BREAKDOWN -.. } \\
\text { FACIL. STANORD. WKPKG } \\
===============\end{array}$} & 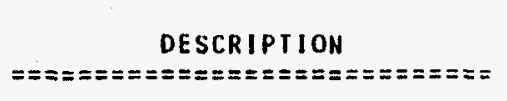 & $\begin{aligned} & \text { QUANIII } \\
&=======\end{aligned}$ & & $\begin{array}{l}\text { MANHOUR S } \\
========\end{array}$ & $\operatorname{lABOR}_{=======}$ & $\begin{array}{l}\text { EQUIP } \\
\text { USAGE } \\
========\end{array}$ & $\begin{array}{l}\text { MA IER IAL } \\
========\end{array}$ & $\begin{array}{l}\text { SUB- } \\
\text { CONIRACT } \\
=======\end{array}$ & $\begin{array}{l}\text { EQUIP. } \\
\text { MENI } \\
=======\end{array}$ & $\begin{array}{c}S / C \\
\text { OH\&P } \\
=======\end{array}$ & $\begin{array}{c}\text { IUIAI } \\
\text { DOLIARS } \\
=======-\end{array}$ \\
\hline 200 & .222400 & $\begin{array}{l}\text { REBAR-RING FOUNDATIONS } \\
\text { SO' CLEAN COAL THICKENER }\end{array}$ & 7400 & LB & 71 & 2785 & 422 & 1726 & 0 & 0 & 215 & 5148 \\
\hline 200 & .222405 & $\begin{array}{l}\text { REQAR-RING FOUNDAIIONS } \\
55 \text { ' REFUSE THICKENER }\end{array}$ & 7800 & LB & 75 & 2942 & 445 & 1819 & 0 & 0 & 226 & 3432 \\
\hline $\begin{array}{l}200 \\
200 \\
200\end{array}$ & $\begin{array}{l}.222500 \\
.223000 \\
.223400\end{array}$ & $\begin{array}{l}\text { REBAR-SMALL PIERS } \\
\text { EMBEDDED MEIALS-EQUIP FDNS } \\
\text { EMB METALS-RING FOUNDATIONS } \\
\text { SO' CLEAN COAL THICKENER }\end{array}$ & $\begin{array}{r}3125 \\
260 \\
400\end{array}$ & $\begin{array}{l}\text { LB } \\
\text { LB } \\
\text { LB }\end{array}$ & $\begin{array}{l}31 \\
13 \\
20\end{array}$ & $\begin{array}{r}1256 \\
463 \\
786\end{array}$ & $\begin{array}{r}184 \\
0 \\
0\end{array}$ & $\begin{array}{l}729 \\
413 \\
636\end{array}$ & $\begin{array}{l}0 \\
0 \\
0\end{array}$ & $\begin{array}{l}0 \\
0 \\
0\end{array}$ & $\begin{array}{l}91 \\
41 \\
64\end{array}$ & $\begin{array}{r}2260 \\
917 \\
1486\end{array}$ \\
\hline 200 & .223405 & $\begin{array}{l}\text { EMB METALS-RING FOUNDATIONS } \\
55^{\circ} \text { REFUSE IHICKENER }\end{array}$ & 400 & LB & 20 & 786 & 0 & 636 & 0 & 0 & 64 & 1480 \\
\hline $\begin{array}{l}200 \\
200\end{array}$ & $\begin{array}{l}.223500 \\
.224000\end{array}$ & $\begin{array}{l}\text { EMBEDDED METALS-SM PIERS } \\
\text { CONCRETE-EOUIP FOUNDATIONS } \\
3000 \text { PSI }\end{array}$ & $\begin{array}{r}100 \\
52\end{array}$ & $\begin{array}{l}1 \mathrm{~B} \\
\mathrm{CY}\end{array}$ & 90 & $\begin{array}{r}178 \\
2759\end{array}$ & $\begin{array}{r}0 \\
550\end{array}$ & $\begin{array}{r}159 \\
2811\end{array}$ & $\begin{array}{l}0 \\
0\end{array}$ & $\begin{array}{l}0 \\
0\end{array}$ & $\begin{array}{r}10 \\
336\end{array}$ & $\begin{array}{r}353 \\
0456\end{array}$ \\
\hline 200 & .224403 & $\begin{array}{l}\text { CONCREIE-RING FDNS-PUMPED } \\
3000 \text { PSI } \\
50^{\circ} \text { CLEAN COAI IHICKENER }\end{array}$ & 75 & CY & 125 & 4528 & 692 & 4055 & 0 & 0 & $\div 75$ & $9 / 511$ \\
\hline 200 & .224404 & $\begin{array}{l}\text { CONCRETE-RING FDNS-PUMPED } \\
3000 \text { PSI } \\
55^{\circ} \text { REFUSE THICKENER }\end{array}$ & 80 & C:Y & 133 & 4818 & 738 & 4325 & a & 0 & sue & 111301 \\
\hline 200 & .224500 & $\begin{array}{l}\text { CONCRETE - SMALL PIERS, } \\
3000 \text { PSI }\end{array}$ & 25 & CY & 45 & 1380 & 276 & 1352 & 0 & 0 & 163 & 3181 \\
\hline 200 & .231100 & $\begin{array}{l}\text { FORMS - MAT FOUNDATIONS } \\
\text { 50' CLEAN COAL. THICKENER }\end{array}$ & 120 & SF & 20 & 768 & 12 & 93 & 0 & 0 & 11 & 8364 \\
\hline 200 & .2311001 & $\begin{array}{l}\text { FORMS - MAT FOUNDATIONS } \\
55 \text { ' REFUSE THICKENER }\end{array}$ & 132 & SF & 22 & 845 & 14 & 102 & D & 0 & 12 & $9 / 3$ \\
\hline 200 & .232100 & $\begin{array}{l}\text { REBAR - MAT FOUNDATIONS } \\
\text { 50' CLEAN COAL THICKENER }\end{array}$ & 12875 & LB & 129 & 5060 & 766 & 3002 & 0 & 0 & 377 & 9205 \\
\hline 200 & .2321001 & $\begin{array}{l}\text { REBAR - MAT FOUNDATIONS } \\
\text { 55. REFUSE THICKENER }\end{array}$ & 15000 & LB & 150 & 5884 & 892 & 3498 & 0 & 0 & 439 & 10713 \\
\hline 200 & .233150 & $\begin{array}{l}\text { ANCHOR BOLTS - MAT FOUNDATIONS } \\
\text { 50' CLEAN COAL THICKENER }\end{array}$ & 120 & LB & 5 & 197 & 0 & 191 & 0 & 0 & 19 & 407 \\
\hline 200 & .2331501 & $\begin{array}{l}\text { ANCHOR BOLTS-MAT FOUNDATIONS } \\
551 \text { RE FUSE THICKENER }\end{array}$ & 120 & LB. & 5 & 197 & 0 & 191 & 0 & 0 & 19 & 407 \\
\hline 200 & .234103 & $\begin{array}{l}\text { CONCRETE - MAT FDNS PUMPED } \\
3000 \text { PSI } \\
50^{\circ} \text { CLEAN COAL IHICKENER }\end{array}$ & 105 & cr & 49 & 1775 & 269 & 5676 & 0 & 0 & 595 & 8315 \\
\hline 200 & .2341031 & $\begin{array}{l}\text { CONCRETE - MAT FONS PUMPED } \\
3000 \text { PSI } \\
551 \text { REFUSE IHICKENER }\end{array}$ & 120 & CY & 55 & 1992 & 307 & 6487 & 0 & 0 & 679 & 9465 \\
\hline $\begin{array}{l}200 \\
200 \\
200\end{array}$ & $\begin{array}{l}.241300 \\
.242300 \\
.244303\end{array}$ & $\begin{array}{l}\text { FORMS - SUSPENDED SLAB } \\
\text { REBAR - SUSPENDED SLAB } \\
\text { CONCREIE - SUSPENDED SLAB } \\
\text { PUMPED, } 3000 \text { PSI }\end{array}$ & $\begin{array}{r}1420 \\
11400 \\
230\end{array}$ & $\begin{array}{l}\text { SF } \\
\text { LB } \\
\text { CY }\end{array}$ & $\begin{array}{l}241 \\
114 \\
347\end{array}$ & $\begin{array}{r}8262 \\
4617 \\
10455\end{array}$ & $\begin{array}{r}195 \\
673 \\
1922\end{array}$ & $\begin{array}{r}1641 \\
2658 \\
12434\end{array}$ & $\begin{array}{l}0 \\
0 \\
0\end{array}$ & $\begin{array}{l}0 \\
0 \\
0\end{array}$ & $\begin{array}{r}184 \\
333 \\
1436\end{array}$ & $\begin{array}{r}10282 \\
8281 \\
26247\end{array}$ \\
\hline 200 & .431306 & $\begin{array}{l}\text { VAPOR BARRIER-6 MIL POLY } \\
\text { OFFICE AREA }\end{array}$ & 1200 & SF & 3 & 103 & 0 & 22 & 0 & 0 & 2 & 127 \\
\hline
\end{tabular}


ICF KAISER ENGINEERS, INC. DEPARTMENT OF ENERGY JOB NO. 8B107-250-00
ICF KAISER ENGINEERS INIERACIIVE ESIIMAIING 20 IPH CLEAN COAL SEMI-WORKS CONCEPIUAL DESIGM GENERAL ESTIMAIE FOR REFERANCE
PAGE 3

DAIE: 07/13/44 13:21 BY

KEPORT D1 - ESIIMATE DETAIL BY FACILITY

\begin{tabular}{|c|c|c|c|c|c|c|c|c|c|c|c|c|c|}
\hline \multicolumn{3}{|c|}{$\begin{array}{l}=\text { - WORK BREAKDOWN -.. } \\
\text { FACIL. STANDRD. WKPKG } \\
=================\end{array}$} & 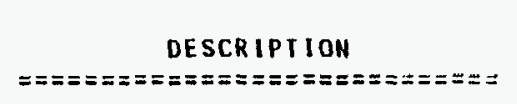 & $\begin{array}{l}\text { QUANIII } \\
=======\end{array}$ & $===$ & $\begin{array}{l}\text { MANHOURS } \\
=======\end{array}$ & $\begin{array}{l}\text { LABOR } \\
=\Xi=\equiv=\approx==\end{array}$ & $\begin{array}{l}\text { EQUIP } \\
\text { USAGE } \\
=======\end{array}$ & $\begin{array}{l}\text { MAIERIAL } \\
== \pm=====\end{array}$ & $\begin{array}{l}\text { SUB- } \\
\text { CONTRACI } \\
===== \pm=\end{array}$ & $\begin{array}{l}\text { EOUIP. } \\
\text { MENT } \\
========\end{array}$ & $\begin{array}{c}S / C \\
\text { OH\&P } \\
=======\end{array}$ & $\begin{array}{c}\text { IUIAI } \\
\text { DOLIARS } \\
=======.\end{array}$ \\
\hline \multirow[t]{2}{*}{200} & .432212 & - & $\begin{array}{l}\text { F.G. INSULATION RIGID - WALL } \\
\text { 2" THICK - RO.3 } \\
\text { OFFICE AREA }\end{array}$ & 1200 & SF & 10 & 343 & 0 & 1094 & 0 & 0 & 109 & 1540 \\
\hline & & TOIAL & CONCRETE AND FOUNDAIIONS & & & 6,512 & 239,827 & 24.678 & 141,066 & $\mathbf{0}$ & 0 & 16,578 & 422,149 \\
\hline 300 & & & SIRUCTURAL STEEL & & & & & & & & & & \\
\hline 300 & .310110 & . & $\begin{array}{l}\text { STRUCTURAL SIEEL - LIGHT } \\
\text { UP TO } 25 L B / L F\end{array}$ & 49 & rON & 980 & 38269 & 5669 & 110113 & 0 & 0 & 11578 & 165629 \\
\hline 300 & .3101101 & & $\begin{array}{l}\text { SIRUCIURAL STEEL IIGHI } \\
\text { EOUIPMENT FOUNDATIONS }\end{array}$ & 560 & LB & 8 & 312 & 45 & 712 & 0 & 0 & 76 & 11.9 \\
\hline 300 & .310120 & - & $\begin{array}{l}\text { STRUCTURAL STEEL - MEDIUM } \\
25 \text { LB/LF TO } 49 \mathrm{LB} / \mathrm{LF}\end{array}$ & 190 & ION & 2850 & 111293 & 16486 & 314184 & $\mathbf{0}$ & 0 & 33067 & $\therefore 73050$ \\
\hline 300 & .310130 & 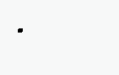 & $\begin{array}{l}\text { STRUCTURAL STEEL - HEAVY } \\
\text { OVER } 50 \text { LB/LF }\end{array}$ & 15 & ION & 180 & 7029 & 1041 & 20352 & 0 & 0 & 2139 & 30,501 \\
\hline $\begin{array}{l}300 \\
300 \\
300\end{array}$ & $\begin{array}{l}.321110 \\
.322105 \\
.324000\end{array}$ & $\dot{.}$ & $\begin{array}{l}\text { GRAIING -PLAIFORMS GAIV.SIL } \\
1 / 4 " \text { PLATEWORK O SUMPS } \\
\text { SIAIR INCLUDING SUPPORI SIEEL } \\
\text { \& HANDRAIL }\end{array}$ & $\begin{array}{l}661 \\
690 \\
101\end{array}$ & $\begin{array}{l}\text { SF } \\
\text { L.B } \\
\text { I.F }\end{array}$ & $\begin{array}{r}99 \\
8 \\
162\end{array}$ & $\begin{array}{r}4072 \\
314 \\
6372\end{array}$ & $\begin{array}{r}398 \\
33 \\
1385\end{array}$ & $\begin{array}{r}7882 \\
775 \\
8672\end{array}$ & $\begin{array}{l}0 \\
0 \\
0\end{array}$ & $\begin{array}{l}0 \\
0 \\
0\end{array}$ & $\begin{array}{r}828 \\
81 \\
11106\end{array}$ & $\begin{array}{r}13180 \\
1203 \\
17435\end{array}$ \\
\hline \multirow[t]{2}{*}{$\begin{array}{l}300 \\
300 \\
300\end{array}$} & $\begin{array}{l}.325100 \\
.331200 \\
.399110\end{array}$ & $\dot{.}$ & $\begin{array}{l}\text { LADDERS WITH CAGE } \\
\text { PLATEWORK }\end{array}$ & $\begin{array}{r}10 \\
6 \\
260 \\
-\end{array}$ & $\begin{array}{l}1 \mathrm{~F} \\
\text { YON } \\
\text { ION }\end{array}$ & $\begin{array}{r}7 \\
240 \\
702 \\
\end{array}$ & $\begin{array}{r}277 \\
9367 \\
27483 \\
\end{array}$ & $\begin{array}{r}48 \\
1364 \\
3250\end{array}$ & $\begin{array}{r}578 \\
15264 \\
11024\end{array}$ & $\begin{array}{l}0 \\
0 \\
0\end{array}$ & $\begin{array}{l}0 \\
0 \\
0\end{array}$ & $\begin{array}{r}63 \\
1663 \\
1627\end{array}$ & $\begin{array}{r}960 \\
21658 \\
43184\end{array}$ \\
\hline & & TOTAL & SIRUCTURAL STEEL & & & 5,236 & 204,788 & 29,719 & 489.556 & 0 & 0 & 51.928 & 775,991 \\
\hline 00 & & & ARCHIJECTURAL WORK & & & & & & & & & & \\
\hline 400 & .284109 & - & $\begin{array}{l}\text { 10" TUICK PRECASI DOOR } \\
\text { HINTELS }\end{array}$ & 93 & 1.1 & 16 & 622 & 200 & 1949 & 0 & 0 & 215 & 2986 \\
\hline 400 & .353186 & . & $\begin{array}{l}\text { MEIAL STUDS AND JOISTS, GALV. } \\
18 \text { GA.: 6" }\end{array}$ & 572 & LF & 13 & 510 & 53 & 609 & 0 & 0 & 66 & 1238 \\
\hline 400 & .415210 & . & $\begin{array}{l}\text { CMU BLOCK WALLS, 10" } \\
\text { EVERY OTHER CELL GROUTED } \\
1 \text { LB REBAR/SF }\end{array}$ & 3871 & St & 503 & 17921 & 394 & 12023 & 0 & 0 & 1242 & 31580 \\
\hline 600 & .4152101 & & $\begin{array}{l}\text { CMU BLOCK WALLS, 10" } \\
\text { LINTEL BLOCK }\end{array}$ & 437 & L.F & 78 & 2779 & 61 & 5605 & 0 & 0 & 567 & 9012 \\
\hline 00 & .415406 & . & $\begin{array}{l}\text { CMU BLOCK WALLS, 6" } \\
\text { LINTEL BLOCK AT TOP OF WALL }\end{array}$ & 126 & Lf & 22 & 784 & 17 & 821 & 0 & 0 & 84 & 1700 \\
\hline 600 & .432111 & - & $\begin{array}{l}\text { INSULATION, 3-1/2" BAIT-RII } \\
\text { FOIL FACED }\end{array}$ & 4187 & SF & 21 & 819 & 0 & 1021 & 0 & 0 & 102 & 1942 \\
\hline $\begin{array}{l}400 \\
400 \\
400 \\
400\end{array}$ & $\begin{array}{l}.434618 \\
.434622 \\
.434624 \\
.437100\end{array}$ & : & $\begin{array}{l}\text { SIOING GALV RIBBED STL } 18 G A \\
\text { SIDING GALV RIBBED STL } 226 A \\
\text { SIOING GALV RIBBED SIL } 24 G A \\
\text { FLASHING METAL, AVG. }\end{array}$ & $\begin{array}{r}16632 \\
7863 \\
20924 \\
1025\end{array}$ & $\begin{array}{l}\text { SF } \\
\text { SF } \\
\text { SF } \\
\text { SF }\end{array}$ & $\begin{array}{r}685 \\
331 \\
871 \\
62\end{array}$ & $\begin{array}{r}23526 \\
12191 \\
32082 \\
2420\end{array}$ & $\begin{array}{r}615 \\
298 \\
795 \\
0\end{array}$ & $\begin{array}{r}53189 \\
20979 \\
52565 \\
2499\end{array}$ & $\begin{array}{l}0 \\
0 \\
0 \\
0\end{array}$ & $\begin{array}{l}0 \\
0 \\
0 \\
0\end{array}$ & $\begin{array}{r}5380 \\
2128 \\
5336 \\
250\end{array}$ & $\begin{array}{r}82710 \\
35596 \\
90778 \\
5169\end{array}$ \\
\hline
\end{tabular}


ICF KAISER ENGINEERS, INC.

DEPARTMENT OF ENERGY

JOB NO. B8107-250-00
ICF KAISER ENGINEERS INIERACIIVE ESTIMATING

20 IPII CIEAN COAL SEMI-WORKS CONCEPTUAL DESIGN

GENERAL ESIIMAIE FOR REFERANCE
REPORI D1. ESTIMAIE OETAIL BY FACILII
PAGE 4

DAIE : $07 / 13 / 94 \quad 13: 28$

\begin{tabular}{|c|c|c|c|c|c|c|c|c|c|c|c|c|}
\hline $\begin{array}{l}- \text { - WOI } \\
\text { fACII } \\
====\end{array}$ & $\begin{array}{l}\text { RK BREAKDOWN -.- } \\
\text { L.STANDRD. WKPKG } \\
=============\end{array}$ & 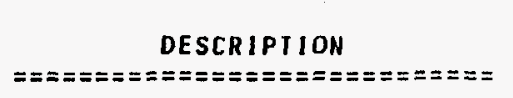 & $\begin{array}{l}\text { QUANIII } \\
=======\end{array}$ & & $\begin{array}{l}\text { MANHOURS } \\
=======\end{array}$ & $\begin{aligned} & \text { LABOR } \\
&=======\end{aligned}$ & $\begin{array}{l}\text { EQUIP } \\
\text { USAGE } \\
=======\end{array}$ & $\begin{array}{l}\text { MATER IAL } \\
=======\end{array}$ & $\begin{array}{l}\text { SUB- } \\
\text { CONIRACI } \\
=======\end{array}$ & $\begin{array}{l}\text { EQUIP. } \\
\text { MENT } \\
===\approx===\end{array}$ & $\begin{array}{c}S / C \\
\text { OH\&P } \\
=======\end{array}$ & $\begin{array}{c}\text { IOIAL } \\
\text { DOLLARS } \\
=======\end{array}$ \\
\hline 400 & .441012 & $\begin{array}{l}\text { DOOR HM SINGLE, } 20 \text { GA.W/FRAME } \\
\text { AND HEAVY HARDWARE AVG. }\end{array}$ & 15 & EA & 67 & 2368 & 0 & 11852 & 0 & 0 & 1185 & 13 ins \\
\hline 400 & .441062 . & $\begin{array}{l}\text { DOOR, HM, DOUBLE, } 18 G A . W . F R A M E \\
\text { \& HEAVY HAROWARE AVG. } \\
\text { FIRERAIED }\end{array}$ & $i$ & $E A$ & 4 & 141 & 0 & 1311 & 0 & 0 & 131 & isus \\
\hline 400 & .441065 & $\begin{array}{l}\text { DOUBLE HM DOOR H/HEAVY } \\
\text { HARDWARE } 4^{\circ} \times 10^{\prime}\end{array}$ & 1 & EA & 8 & 313 & 0 & 1908 & 0 & 0 & 191 & 2412 \\
\hline 400 & .441214 . & $\begin{array}{l}\text { DOUBLE HM DOOR W/HEAVY } \\
\text { HARDWARE } 4^{\circ} \times 7^{\circ}\end{array}$ & 3 & EA & 15 & 586 & 0 & 4770 & 0 & 0 & 477 & 5833 \\
\hline $\begin{array}{l}400 \\
400 \\
400\end{array}$ & $\begin{array}{l}.441603 \\
.443200 \\
.443280\end{array}$ & $\begin{array}{l}\text { TRANSOM REMOVABLE } \\
\text { DOOR ROLL-UP (NO OPERATOR) } \\
\text { MOTOR OPERATOR AND SAFEIY BAR } \\
\text { FOR ROLL-UP DOOR }\end{array}$ & $\begin{array}{r}34 \\
200 \\
2\end{array}$ & $\begin{array}{l}S F \\
S F \\
E A\end{array}$ & $\begin{array}{r}9 \\
32 \\
8\end{array}$ & $\begin{array}{r}352 \\
1323 \\
331\end{array}$ & $\begin{array}{l}0 \\
0 \\
0\end{array}$ & $\begin{array}{r}541 \\
2258 \\
2406\end{array}$ & $\begin{array}{l}0 \\
0 \\
0\end{array}$ & $\begin{array}{l}0 \\
0 \\
0\end{array}$ & $\begin{array}{r}54 \\
226 \\
241\end{array}$ & $\begin{array}{r}947 \\
3807 \\
2978\end{array}$ \\
\hline $\begin{array}{l}400 \\
400 \\
400\end{array}$ & $\begin{array}{l}.445220 \\
.446113 \\
.454311\end{array}$ & $\begin{array}{l}\text { WINDOW-STL INSULATEO GLASS } \\
\text { TEMPERED GLASS } \\
\text { IERRAZZO CAST-IN-PLACE } \\
1-3 / 4 ", \text { GRAY CEMENT }\end{array}$ & $\begin{array}{r}32 \\
13 \\
1400\end{array}$ & $\begin{array}{l}S F \\
S F \\
S F\end{array}$ & $\begin{array}{r}3 \\
3 \\
98\end{array}$ & $\begin{array}{r}118 \\
117 \\
3632\end{array}$ & $\begin{array}{r}0 \\
0 \\
182\end{array}$ & $\begin{array}{r}397 \\
103 \\
2834\end{array}$ & $\begin{array}{l}0 \\
0 \\
0\end{array}$ & $\begin{array}{l}0 \\
0 \\
0\end{array}$ & $\begin{array}{r}40 \\
10 \\
302\end{array}$ & $\begin{array}{r}555 \\
230 \\
6950\end{array}$ \\
\hline 400 & .454326 & $\begin{array}{l}\text { TERRAZZO BASE CAST-IN-PLACE } \\
6 "\end{array}$ & 247 & $S F$ & 17 & 630 & 31 & 270 & 0 & 0 & 30 & ye 1 \\
\hline $\begin{array}{l}400 \\
400 \\
400\end{array}$ & $\begin{array}{l}.455100 \\
.456186 \\
.459111\end{array}$ & $\begin{array}{l}\text { CEILING MINERAL FIBER SUSPEND } \\
\text { FIR BASE VINYL/RUBBER 6" } \\
\text { PAINIING - MASONRY BLOCK WALL } \\
2 \text { COATS BRUSHED }\end{array}$ & $\begin{array}{r}1470 \\
62 \\
15000\end{array}$ & $\begin{array}{l}\text { SF } \\
\text { LF } \\
\text { SF }\end{array}$ & $\begin{array}{r}34 \\
2 \\
150\end{array}$ & $\begin{array}{r}1329 \\
78 \\
5265\end{array}$ & $\begin{array}{r}0 \\
0 \\
480\end{array}$ & $\begin{array}{r}1901 \\
39 \\
1113\end{array}$ & $\begin{array}{l}0 \\
0 \\
0\end{array}$ & $\begin{array}{l}0 \\
0 \\
0\end{array}$ & $\begin{array}{r}190 \\
4 \\
159\end{array}$ & $\begin{array}{l}\sin 20 \\
121 \\
017\end{array}$ \\
\hline 400 & .461505 & $\begin{array}{l}\text { WASTE RECEPTACLES W/SWING } \\
\text { TOP } 13 \text { GAL. CAP. } \\
\text { \#2250 }\end{array}$ & 5 & $E A$ & 20 & 782 & 0 & 806 & 0 & 0 & 81 & 1604 \\
\hline 400 & .461510 & $\begin{array}{l}\text { PAPER TOWEL DISPENSER } \\
\text { W/MIRROR AND SOAP DI SPENSER } \\
\text { SURFACE MOUNIED \#B3309 }\end{array}$ & 48 & $E A$ & 16 & 625 & 0 & 1153 & 0 & 0 & 115 & 1893 \\
\hline 400 & .461515 & $\begin{array}{l}\text { PAPER IOWEL DISPENSER } \\
\text { SURFACE MOUNTED } \\
\$ 262\end{array}$ & 2 & $E A$ & 4 & 156 & 0 & 87 & 0 & 0 & 9 & 252 \\
\hline 400 & .461520 & $\begin{array}{l}\text { SOAP DISPENSER (LIQUID) } \\
\text { SURFACE MOUNTEO } \\
\text { \#B150 }\end{array}$ & $2 E$ & EA & 4 & 156 & 0 & 22 & 0 & 0 & 2 & 180 \\
\hline 400 & .461525 . & $\begin{array}{l}\text { MIRROR } \\
\forall B 292 \\
\forall B 24 \times 30) \text { AND SHEIF }\end{array}$ & $1 \mathrm{E}$ & EA & 4 & 156 & 0 & 131 & 0 & 0 & 13 & 3110 \\
\hline 400 & .461530 & $\begin{array}{l}\text { TOILEI TISSUE DISPENSER } \\
\text { DOUBLE ROLL W/SHELF } \\
\text { \#B2B407 }\end{array}$ & $2 E$ & EA & 4 & 156 & 0 & 242 & 0 & 0 & 24 & 422 \\
\hline 400 & .461535 . & $\begin{array}{l}\text { SANITARY NAPKIN DISPENSER } \\
\text { /SURFACE MOUHTED } \\
\text { HB282 }\end{array}$ & $1 \mathrm{E}$ & EA & 4 & 156 & 0 & 297 & 0 & 0 & 30 & 483 \\
\hline 400 & .461540 & $\begin{array}{l}\text { SAHITARY NAPKIN DISPOSAL } \\
\text { HIUTILITY SELF-SERVICE } \\
\text { MOUNTED \#B271 }\end{array}$ & $1 \mathrm{E}$ & EA & 4 & 156 & 0 & 38 & 0 & 0 & 4 & 198 \\
\hline
\end{tabular}


ICF KAISER ENGINEERS, INC. DEPARTMENT OF ENERGY JOB NO. BB107-250-00
ICF KAISER ENGINEERS INIERACTIVE ESIIMATING 20 IPII CIEAN COAL SEMI. WORKS CONCEPIUAL DESIGN GENERAL ESTIMATE FOR REFERANCE

REPORT D1 - ESTIMATE DETAIL BY FACILIIY
PAGE 5

DATE : $07 / 13 / 94 \quad 13: 21$ BY

- - WORK BREAKDOWN-.FACIL.STANDRO. WKPKG

DESCRIPTION

EOUIP
OUANIITY MANHOURS LABOR USAGE MATERIAL CONTRACT MQUIP.
S/C

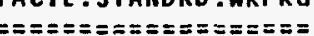

DESCRIPTION DUANIIT MANHOURS LABOR USAGE MATERIAL CONTRACI MEHT OHBP VOLLARS

\begin{tabular}{|c|c|c|}
\hline 400 & .461545 & $\begin{array}{l}\text { COAT HOOK SIRIP ( } 3 \text { HOOK } \\
\text { B } 232 \times 24\end{array}$ \\
\hline 400 & .461550 & $\begin{array}{l}\text { MOP AND BROOM HOLDER } \\
\text { W/SHEL.F } \\
\text { B239X34 }\end{array}$ \\
\hline 400 & .461555 & $\begin{array}{l}\text { SIAINLESS STEEL SHELF } \\
\text { B2 } 296 \times 24\end{array}$ \\
\hline 400 & .461560 & $\begin{array}{l}\text { SHOWER STALL CURTAIN RO } \\
\text { H/VINYL SHOWER CURTAI } \\
\text { HOOKS } \$ 204-2\end{array}$ \\
\hline 600 & .461565 & $\begin{array}{l}\text { HEAVY DUTY ROBE HOOK } \\
\text { B2116 }\end{array}$ \\
\hline 400 & .465100 & $\begin{array}{l}\text { LOCKERS METAL } \\
\text { SINGLE TIER }\end{array}$ \\
\hline 00 & .465200 & $\begin{array}{l}\text { LOCKER BENCH WOOD } \\
\text { W/ PIPE PEDESTALS }\end{array}$ \\
\hline
\end{tabular}

TOIAL ARCHITECTURAL WORK

500 EQUIPMENT INSTALLATION

500.100000 . PLANT FEED CONVEYOR BY OIHERS-NOT PART OT IIIIS PROJECT

500.100100 . PLANT FEED CONVEYOR HEAD END

500.100200 DISCHARGE HOPPER HT. 1300\#

PLANT FEED CONVEYOR DISCHARGE

$\begin{array}{ccccc}3 \text { EA } & 6 & 234 & 0 & 116 \\ 1 \text { EA } & 2 & 78 & 0 & 155 \\ 1 \text { EA } & 2 & 78 & 0 & 33 \\ 3 \text { EA } & 6 & 234 & 0 & 143 \\ 3 \text { EA } & 6 & 234 & 0 & 38 \\ 16 \text { EA } & 13 & 508 & 0 & 1526 \\ 8 \text { IF } & 1 & 39 & 0 & 132\end{array}$

.

$3,148 \quad 3,126$

187,882

CHUTE FROM HOPPER TO CRUSHER

$$
113,985
$$

$1 \mathrm{E}$

1 EA $\quad 32 \quad 1243$

$1 E A \quad 32$

1243

1 EA 24

933

ERIEZ MODEL SE7235MC

BEIT MAGNET RECTIFIER

500.105100.

ERIEZ MODEL 36C-1800WATTS

RAW COAL CRUSHER \#

GUNDLACH MODEL 450A

500.110000 .

\#1 RAH COAL CRUSHER DISCHARge CHUTE IO RAW COAL CRUSHER \#2 WT. 1100 H

500.111000 .

RAW COAL CRUSHER \#2

GUNDLACH MODEL 450 A

$500 \quad .111100$

RAH COAL CRUSHER \#2 DISCHARGE

CHUIE TO RAW COAL SCREEN

$500 \quad .112000$ 
ICF KAISER ENGINEERS, INC. DEPARTMENT OF ENERGY

JOB NO. $88107-250-00$
ICF KAISER ENLINEERS INIERACIIVE ESIIMAIING 20 IPII CLEAN COAI SEMI-WORKS CONCEPTUAL DESIGN GENERAL ESTIMAIE FOR REFERANCE
PALit 6

DAIE: $07 / 13 / 44 \quad 13: 21$

REPORT D1 - ESIIMAIE DETAIL BY FACILITY

BY

\begin{tabular}{|c|c|c|c|c|c|c|c|c|c|c|c|}
\hline $\begin{array}{l}- \text {-WO } \\
\text { FACI } \\
====\end{array}$ & $\begin{array}{l}\text { QK BREAKDOWN }-. . \\
\text {.STANDRD. WKPKG } \\
==============\end{array}$ & 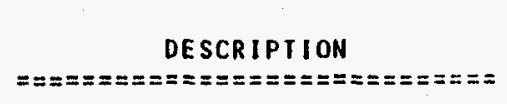 & $\begin{array}{l}\text { QUAN IIIY } \\
========\end{array}$ & $\begin{array}{l}\text { MANHOURS } \\
=======\end{array}$ & $\begin{array}{l}\operatorname{LABOR} \\
=======\end{array}$ & $\begin{array}{l}\text { EQUIP } \\
\text { USAGE } \\
=======\end{array}$ & $\begin{array}{l}\text { MATERIAL } \\
=======\end{array}$ & $\begin{array}{l}\text { SUB- } \\
\text { CONTRACI } \\
=======\end{array}$ & $\begin{array}{l}\text { EQUIP - } \\
\text { MENI } \\
=======\end{array}$ & $\begin{aligned} & S / C \\
& \text { OH\&P } \\
&===\approx===\end{aligned}$ & $\begin{array}{c}\text { IUIAI } \\
\text { DOLIARS } \\
:======-\end{array}$ \\
\hline 500 & .112100 & $\begin{array}{l}\text { RAW COAL SCREEN IINDER FLOW } \\
\text { PAN TO COLLECT FINES } \\
\text { WT. } 2000 \#\end{array}$ & $1 \mathrm{EA}$ & 64 & 2487 & 549 & 3180 & 0 & 0 & 373 & $\cos 84$ \\
\hline 500 & .112200 & $\begin{array}{l}\text { RAW COAL SCREEN OVER FI OW } \\
\text { HOPPER AND CHUTE } \\
\text { WT. } 1400 \#\end{array}$ & $1 E A$ & 32 & 1243 & 274 & 2226 & 0 & 0 & 250 & 3403 \\
\hline 500 & .113000 & $\begin{array}{l}\text { OVERSIZE BUCKEI ELEVAIOR } \\
\text { GOODMAN }\end{array}$ & $1 \mathrm{EA}$ & 400 & 15543 & 3429 & 0 & 0 & 25355 & 343 & $446 / 0$ \\
\hline 500 & .113200 & $\begin{array}{l}\text { OVERSIZE BUCKET ELEVATOR TOP } \\
\text { DISCHARGE CHUTE } \\
\text { WI. } 600 \#\end{array}$ & $1 \mathrm{EA}$ & 24 & 933 & 206 & 1060 & 0 & 0 & 127 & 2320 \\
\hline 500 & .115000 & $\begin{array}{l}\text { RAW COAL FEED SUMP } \\
\text { WT. } 3000 \#\end{array}$ & $1 E A$ & 120 & 4663 & 1029 & 5300 & 0 & u & 033 & 11024 \\
\hline 500 & .120000 & $\begin{array}{l}\text { RAW COAL FEED PUMP } \\
\text { GOYNE PUMP }\end{array}$ & $1 \mathrm{EA}$ & 32 & 1243 & 274 & 0 & 0 & 13627 & 27 & 15171 \\
\hline 500 & .135000 & $\begin{array}{l}\text { REFUSE CENIRIFUGE DRIVE } \\
\text { MODEL CMI HVC- } 20\end{array}$ & $1 \in A$ & 32 & 1243 & 274 & 0 & 0 & 86920 & 27 & $88.0: 0$ \\
\hline 500 & .135100 & $\begin{array}{l}\text { REFUSE CENTRIFUGE VIBRAIOR } \\
\text { MODEL CMI HVC- } 20\end{array}$ & I EA & 24 & 933 & 206 & 0 & 0 & 0 & 21 & 1160 \\
\hline 500 & .135200 . & $\begin{array}{l}\text { REFUSE CENIRIFUGE OIL PUMP } \\
\text { MODEL CMI HVC- } 20\end{array}$ & $1 E A$ & 24 & 933 & 206 & 0 & 0 & 0 & 21 & 1160 \\
\hline 500 & .135300 . & $\begin{array}{l}\text { REFUSE CENTRIFUGE ORIVE } \\
\text { DISCHARGECHUIE WT. } 2000 \mathrm{H}\end{array}$ & $1 E A$ & 48 & 1865 & 411 & 3392 & 0 & 0 & 380 & 60148 \\
\hline 500 & .140000 . & $\begin{array}{l}\text { DESLIME SIEVE BEND } \\
\text { 3'WIDE,80"RAD, } 60, .35 \mathrm{MM}, \\
3 / 32 \text { ISO }\end{array}$ & $2 \mathrm{EA}$ & 96 & 3730 & 823 & 0 & 0 & 9752 & 82 & 14387 \\
\hline 500 & .140100 & $\begin{array}{l}\text { DESLIME SIEVE BEND DISCHARGE } \\
\text { CHUTE WT. } 700 \#\end{array}$ & 2 EA & 64 & 2487 & 549 & 2332 & 0 & 0 & 288 & 5656 \\
\hline 500 & .145000. & $\begin{array}{l}\text { DESL IME SCREEN } \\
\text { TABOR } 4 \text { ' } X \text { I2'SID. VIBRATING } \\
\text { HORIZONIAL }\end{array}$ & 1 EA & 160 & 6217 & 1371 & 0 & 0 & 20670 & 137 & 28545 \\
\hline 500 & .145100 . & $\begin{array}{l}\text { DESLIME SCREEN DI SCHARGE } \\
\text { CHUTE } \# 1 \mathrm{WT} .600 \#\end{array}$ & $1 E A$ & 32 & 1243 & 274 & 954 & 0 & 0 & 123 & 2594 \\
\hline 500 & .145200 & $\begin{array}{l}\text { DESLIME SCREEN DISCHARGE } \\
\text { CHUTE } \# 2 \text { WI. } 1000 \#\end{array}$ & $1 \mathrm{EA}$ & 32 & 1243 & 274 & 1590 & 0 & 0 & 186 & 3293 \\
\hline 500 & .145300 & $\begin{array}{l}\text { DESLIIME SCREEN UNDERFLOW PAN } \\
\text { WT. } 1400 \#\end{array}$ & 1 EA & 32 & 1243 & 274 & 2226 & 0 & 0 & 250 & 3993 \\
\hline 500 & .145400 & $\begin{array}{l}\text { DESLIME AND MIDLS DISCHARGE } \\
\text { CHUTE HT. } 1500 \#\end{array}$ & 1 EA & 32 & 1243 & 274 & 2650 & 0 & 0 & 292 & 4459 \\
\hline 500 & .150000 & $\begin{array}{l}\text { MIDDLIINGS CRUSHER DRIVE \#1 } \\
\text { GUNDLACH CAGEPACTOR }\end{array}$ & 1 EA & 240 & 9326 & 2057 & 0 & 0 & 125811 & 206 & 137400 \\
\hline 500 & .150100 . & $\begin{array}{l}\text { MIDDLINGS CRUSHER DISCHARGE } \\
\text { CHUTE WT. } 500 \#\end{array}$ & 1 EA & 24 & 933 & 206 & 954 & 0 & 0 & 116 & 2209 \\
\hline 500 & 150200 . & $\begin{array}{l}\text { HIDDLINGS CRUSHER DRIVE } \# 2 \\
\text { GUNDLACH CAGEPACTOR }\end{array}$ & 1 EA & 240 & 9326 & 2057 & 0 & 0 & 0 & 206 & 11589 \\
\hline
\end{tabular}


ICF KAISER ENGINEERS, INC. DEPARTHENT OF ENERGY JOB NO. B8107-250-00
ICF KAISER ENGINEERS INIERACTIVE ESIIMAIING

20 TPII CLEAN COAL SEMI-WORKS CONCEPTUAL DESIGN GENERAL ESTIMAIE FOR REFERANCE

REPURI DI - ESIIMAIE DETAIL BY FACIIIIY
PAGE ?

DAIE : $07 / 13 / 94$ is: 21

\begin{tabular}{|c|c|c|c|c|c|c|c|c|c|c|c|c|}
\hline $\begin{array}{l}- \text { - WO } \\
\text { FACI } \\
====\end{array}$ & $\begin{array}{l}\text { RK BREAKD } \\
\text { L. STANDRD } \\
====\approx====\end{array}$ & $\begin{array}{l}\text { OWN -.. } \\
\text { WKPKG } \\
======\end{array}$ & 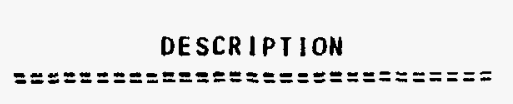 & $\begin{array}{l}\text { QUANIIIY } \\
======= \pm=\end{array}$ & $\begin{array}{l}\text { MANHOURS } \\
========\end{array}$ & $\begin{array}{l}\text { LABOR } \\
=======\end{array}$ & $\begin{array}{l}\text { EQUIP } \\
\text { USAGE } \\
==\equiv====\end{array}$ & $\begin{array}{l}\text { MA IER IAL } \\
=======\end{array}$ & $\begin{array}{l}\text { SUB- } \\
\text { CONTRACT } \\
===== \pm==\end{array}$ & $\begin{array}{l}\text { EQUIP- } \\
\text { MENI } \\
=======\end{array}$ & $\begin{array}{c}\text { S/C } \\
\text { OH\&P } \\
========\end{array}$ & $\begin{array}{c}\text { IOIAI } \\
\text { DOLIARS } \\
========\end{array}$ \\
\hline 500 & .150300 & . & $\begin{array}{l}\text { CRUSHER DISCHARGE CHUTE } \\
\text { PLATEWORK WT. } 1600 \#\end{array}$ & $1 E A$ & 32 & 1243 & 274 & 2650 & 0 & 0 & 292 & 4454 \\
\hline 500 & .151000 & $\cdot$ & $\begin{array}{l}\text { OVERSIZE PROTECTION SIMP } \\
\text { PLATEWORK WT. } 2700 \#\end{array}$ & $1 E A$ & 32 & 1243 & 274 & 5300 & 0 & 0 & 557 & $13 / 4$ \\
\hline 500 & .152000 & . & $\begin{array}{l}\text { OVERSIZE PROTECIION PUMP } \\
\text { GOYHE PUMP }\end{array}$ & $1 E A$ & 32 & 1249 & 168 & D & 0 & 12912 & 17 & 14346 \\
\hline 500 & .153000 & . & $\begin{array}{l}\text { OVERSIZE PROIECIION SIEVE } \\
\text { BEND } 5 \text { 'HIDE, } 40^{\circ R}, 60, .35 \mathrm{MM}, \\
3 / 32 \text { ISO }\end{array}$ & $2 E A$ & 96 & 3730 & 823 & 0 & 0 & 10600 & 82 & 15235 \\
\hline 500 & .153100 & . & $\begin{array}{l}\text { OVERSIZE PROIECTION SIEVE } \\
\text { BEHD DISCHARGE HOPPER } \\
\text { WT. } 500 \#\end{array}$ & 1. EA & 32 & 1243 & 274 & 954 & 0 & 0 & 123 & 2594 \\
\hline 500 & .153200 & - & $\begin{array}{l}\text { OVERSIZE PROTECIION SIEVE } \\
\text { BEND DISCHARGE CHUTE WT. } 1100 \mathrm{H}\end{array}$ & $1 \mathrm{EA}$ & 32 & 1243 & 274 & 1908 & 0 & 0 & 218 & $36 \div 3$ \\
\hline 500 & .155000 & . & $\begin{array}{l}\text { FI HE HYDRO FEED SUMP } \\
\text { PLATEWORK WI. } 2700 \#\end{array}$ & $1 \mathrm{EA}$ & 48 & 1865 & 411 & 5300 & 0 & 0 & 571 & 81.7 \\
\hline 500 & .160000 & . & $\begin{array}{l}\text { FI HE HYDRO FEED PUMP } \\
\text { GOYNE PUMP }\end{array}$ & $1 \mathrm{EA}$ & 32 & 1249 & 168 & 0 & 0 & 14578 & 17 & 161112 \\
\hline 500 & .165000 & . & $\begin{array}{l}\text { FINE "YOROCIONES } \\
\text { KREBS } 10 " \text { DIAMEIER WIIH/SIAND }\end{array}$ & $5 E A$ & 160 & 6217 & 1371 & 0 & 0 & 83475 & 137 & 91200 \\
\hline 500 & .165100 & . & $\begin{array}{l}\text { FINE CYCLONE HOPPER } \\
\text { WT } 1800 \#\end{array}$ & $5 E A$ & 120 & 4663 & 1029 & 15900 & 0 & 0 & 1693 & 232135 \\
\hline 500 & .202000 & . & $\begin{array}{l}\text { CLASSIFYING CYCLONE SUMP } \\
\text { PLAIEWORK HI. } 2700 \mathrm{H}\end{array}$ & $1 \mathrm{EA}$ & 48 & 1865 & 411 & 5300 & 0 & 0 & 571 & 8147 \\
\hline 500 & .205000 & . & $\begin{array}{l}\text { CLASSIFYING CYCLONE PUMP } \\
\text { GOYNE PUMP }\end{array}$ & $1 \mathrm{EA}$ & 32 & 1249 & 168 & 0 & 0 & 30493 & 17 & 31927 \\
\hline 500 & .207000 & - & $\begin{array}{l}\text { CLASSIFYING CYCLONES } \\
\text { KREBS IO" DIAMEIER WITH/SIAND }\end{array}$ & $8 \mathrm{EA}$ & 256 & 9947 & 2194 & 0 & 0 & 127624 & 219 & 139984 \\
\hline 500 & .207100 & . & $\begin{array}{l}\text { CLASSIFYING CYCLONES HOPPER } \\
\text { WT. } 1800\end{array}$ & $8 \mathrm{EA}$ & 192 & 7460 & 1646 & 25440 & 0 & 0 & 2709 & 37255 \\
\hline 500 & .208000 & . & $\begin{array}{l}\text { VARI-SIEVE } \\
\text { KREBS 5'HIDE VARI-SIEVE }\end{array}$ & $2 \mathrm{EA}$ & 96 & 3730 & 823 & 0 & 0 & 103414 & 82 & 108049 \\
\hline 500 & .208100 & - & $\begin{array}{l}\text { VARI-SIEVE DISCHARGE CHUTE } \\
\text { WT. } 1000 \mathrm{H}\end{array}$ & $2 \mathrm{EA}$ & 48 & 1865 & 411 & 3180 & 0 & 0 & 359 & 5815 \\
\hline 500 & .210100 & - & $\begin{array}{l}\text { 10' DIA. } X \text { 6' CONICAL } \\
\text { BALL MILL }\end{array}$ & $1 \mathrm{EA}$ & 800 & 31085 & 6857 & 0 & 0 & 606320 & 686 & 644948 \\
\hline 500 & .210200 & • & $\begin{array}{l}\text { BALL MILL DISCHARGE CHUTE } \\
\text { WT. 3000\# }\end{array}$ & $1 \mathrm{EA}$ & 160 & 6217 & 1371 & 4770 & 0 & 0 & 614 & $124 / 2$ \\
\hline 500 & .215000 & . & $\begin{array}{l}\text { ADVANCED FLOTATION FEED SUMP } \\
\text { PLATEHORK HT. } 2700 \%\end{array}$ & $1 \mathrm{EA}$ & 32 & 1243 & 274 & 5300 & 0 & 0 & 557 & 7374 \\
\hline 500 & .220100 & . & $\begin{array}{l}\text { ADVANCED FLOTATION FEED PUMP } \\
\text { GOYNE PUMP }\end{array}$ & $1 \mathrm{EA}$ & 32 & 1249 & 168 & 0 & 0 & 25803 & 17 & 27251 \\
\hline 500 & .225000 & . & $\begin{array}{l}\text { FLOTATION FEED DISIRIBUTER } \\
\text { PLATEWORK HT. } 2500 \#\end{array}$ & $1 \mathrm{EA}$ & 32 & 1243 & 274 & 5300 & 0 & 0 & 557 & 7374 \\
\hline 500 & .230100 & - & $\begin{array}{l}\text { ADVAHCED FLOIATION CEIL } \\
\text { ICFKE MICROCEL MODEL } 12025\end{array}$ & $4 E A$ & 1600 & 62171 & 13715 & 0 & 0 & 466400 & 1372 & 543658 \\
\hline
\end{tabular}


ICF KAISER ENGINEERS, INC. DEPARTMEHT OF ENERGY JOB NO. B8107-250-00
ICF KAISER ENGIHEERS INIERACIIVE ESIIMAIING

20 IPU CIEAN COAL SEMI-WORKS CONCEPIUAL DESIGH GENERAL ESTIMAIE FOR REFERANCE

REPORI D1 - ESIIMAIE DETAIL BY FACILIIY
PAGE 8

DAIE : $07 / 13 / 44 \quad 13: 28$ BY

\begin{tabular}{|c|c|c|c|c|c|c|c|c|c|c|c|c|c|}
\hline \multicolumn{3}{|c|}{$\begin{array}{l}\text { - WORK BREAKDOWN }-. . \\
\text { FACIL.STANDRD. WKPKG } \\
=====\approx==========\end{array}$} & 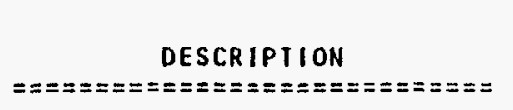 & $\begin{array}{l}\text { QUANIII } \\
========\end{array}$ & & $\begin{array}{l}\text { MANHOURS } \\
=======\end{array}$ & $\begin{aligned} & \operatorname{LABOR} \\
&=======\end{aligned}$ & $\begin{array}{l}\text { EQUIP } \\
\text { USAGE } \\
=======\end{array}$ & $\begin{array}{l}\text { MATER IAL } \\
=======\end{array}$ & $\begin{array}{l}\text { SUB. } \\
\text { CONTRACI } \\
=======\end{array}$ & $\begin{array}{c}\text { EQUIP. } \\
\text { MENI } \\
=======\end{array}$ & $\begin{array}{l}S / C \\
O H \& P \\
======\end{array}$ & $\begin{array}{c}\text { TOIAI } \\
\text { DOLIARS } \\
====== \pm .\end{array}$ \\
\hline 500 & .230200 & . & $\begin{array}{l}\text { ADVANCED FLOTAIION PUMP } \\
\text { GOYNE PUMP }\end{array}$ & $4 E$ & $E A$ & 128 & 4998 & 674 & 0 & 0 & 0 & 67 & 5734 \\
\hline 500 & .240000 & • & $\begin{array}{l}\text { COAL SIAIIC IHICKENER ORIVE } \\
\text { EIMCO SO, DIAMETER HIRATE }\end{array}$ & $1 \mathrm{E}$ & EA & 400 & 15543 & 3429 & 0 & 0 & 68900 & 343 & كأ \\
\hline 500 & .240100 & • & $\begin{array}{l}\text { COAL SIATIC THICKENER LIFIING } \\
\text { DEVICEC, EMICO } 50^{\circ} \text { DIAMEIER } \\
\text { HIRATE }\end{array}$ & $1 \mathrm{E}$ & $E A$ & 128 & 4974 & 1097 & 0 & 0 & 0 & 110 & 6181 \\
\hline 500 & .245000 & - & $\begin{array}{l}\text { COAL THICKENER CLARIFIED } \\
\text { HATER SUMP. PLATEWORK } \\
\text { WT. } 11000 \#\end{array}$ & $1 \mathrm{E}$ & EA & 64 & 2487 & 549 & 18550 & 0 & 0 & 1910 & 23.96 \\
\hline 500 & .247000 & . & $\begin{array}{l}\text { COAL THICKENER CLARIFIED } \\
\text { WAIER PUMP, GOYNE PUMP }\end{array}$ & $i E$ & $E A$ & 64 & 2499 & 337 & 0 & 0 & 30152 & 34 & 331122 \\
\hline 500 & .249000 & . & $\begin{array}{l}\text { COAL STATIC THICKENER UNDER } \\
\text { FLOW PUMP, GOYNE PUMP }\end{array}$ & $1 E$ & EA & 32 & 1249 & 168 & 0 & 0 & 12207 & 17 & $130: 1$ \\
\hline 500 & .260000 & . & $\begin{array}{l}\text { CIEAN COAL FILIER DRIVE, } \\
\text { ANDRIIZ RUIHNER, INC. }\end{array}$ & $1 \mathrm{E}$ & $E A$ & 400 & 15543 & 3429 & 0 & 0 & 1228110 & $3 \div 3$ & 12.48135 \\
\hline 500 & .260100 & . & $\begin{array}{l}\text { AGITAIORS } \\
\text { ANDRIIZ RUTHNER, INC. } \\
\text { W/500.260000 }\end{array}$ & $3 \mathrm{E}$ & EA & 120 & 4663 & 1029 & 0 & 0 & 0 & 1113 & 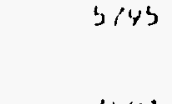 \\
\hline 500 & .260200 & . & $\begin{array}{l}\text { DISCHARGE GATES, } \\
\text { ANDRIIZ RUIHNER, INC. } \\
\text { W/500.260000 }\end{array}$ & $1 E$ & EA & 64 & 2487 & 549 & 0 & 0 & 0 & ss & sim, 1 \\
\hline 500 & .260300 & . & $\begin{array}{l}\text { AIR COMPRESSOR, } \\
\text { AIRIEC }\end{array}$ & $1 \mathrm{E}$ & $E A$ & 200 & 7809 & 1053 & 0 & 0 & 52391 & 105 & 01338 \\
\hline 500 & .260400 & . & $\begin{array}{l}\text { FILTRATE PUMP } \\
\text { GOYNE PUMP }\end{array}$ & $1 \mathrm{E}$ & EA & 64 & 2499 & 337 & 0 & 0 & 8509 & 34 & 11379 \\
\hline 500 & .260500 & . & $\begin{array}{l}\text { LUBRICATOR, } \\
\text { AHDR ITZ RUTHNER, INC. } \\
\text { W/500.260000 }\end{array}$ & $1 \mathrm{E}$ & EA & 32 & 1243 & 274 & 0 & 0 & 0 & $2 r$ & 1544 \\
\hline 500 & .260600 & - & $\begin{array}{l}\text { AUXILLARY AIR COMPRESSOR } \\
\text { ANORITZ RUTHNER, INC. } \\
\text { W/500.260000 }\end{array}$ & $1 \mathrm{E}$ & EA & 64 & 2499 & 337 & 0 & 0 & 0 & 34 & 2810 \\
\hline 500 & $\begin{array}{c}.260700 \\
.1\end{array}$ & - & $\begin{array}{l}\text { INTERHAL CONVEYOR, } \\
\text { ANDRIIZ RUTHNER, INC. } \\
\text { W/500.260000 }\end{array}$ & $1 E$ & EA & 64 & 2487 & 549 & 0 & 0 & 0 & 55 & 3091 \\
\hline 500 & .260800 & - & $\begin{array}{l}\text { CLEAN COAL FILITER DISCHARGE } \\
\text { CHUTE, PLATEWORK WT.900\# }\end{array}$ & $1 \mathrm{E}$ & EA & 32 & 1243 & 274 & 1590 & 0 & 0 & 186 & 3243 \\
\hline 500 & .265000 & . & $\begin{array}{l}\text { CLEAN COAL BELT CONVEYOR } \\
\text { BY OTHERS NOI INCLUDED IN } \\
\text { THIS CONTRACT }\end{array}$ & $1 \mathrm{E}$ & EA & 0 & 0 & 0 & 0 & 0 & 0 & 0 & 0 \\
\hline & & & $\begin{array}{l}\text { LIFTING DEVICE, } \\
\text { EMICO 60! DIAMEIER HIRAIE }\end{array}$ & & & 128 & & & & & & & 6181 \\
\hline
\end{tabular}


ICF KAISER ENGINEERS, INC. DEPARTMENT OF ENERGY JOB NO. 88107-250-00
ICF KAISER ENGINEERS IHIERACIIVE ESIIMAIIMG 20 IPII CIEAN COAL SEMI-WORKS CONCEPTUAL DESIGN GENERAL ESTIMATE FOR REFERANCE

REPORT DI - ESIIMAIE DEIAIL BY FACILITY
PAGE 9

DAIE: $07 / 13 / 94 \quad 13: 27$ BY

\begin{tabular}{|c|c|c|c|c|c|c|c|c|c|c|c|c|c|}
\hline \multicolumn{3}{|c|}{$\begin{array}{l}\text { - WORK BREAKDOWH -.. } \\
\text { FACIL.STANORD.WKPKG } \\
===============\end{array}$} & 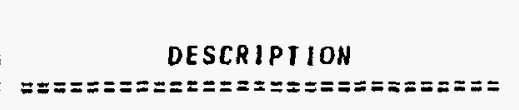 & $\begin{array}{l}\text { QUANTII } \\
======\end{array}$ & & $\begin{array}{l}\text { MANHOURS } \\
========\end{array}$ & $\begin{aligned} & \perp A B O R \\
&========\end{aligned}$ & $\begin{array}{l}\text { EQUIP } \\
\text { USAGE } \\
=======\end{array}$ & $\begin{array}{l}\text { MATER IAL } \\
========\end{array}$ & $\begin{array}{l}\text { SUB- } \\
\text { CONIRACI } \\
=======\end{array}$ & $\begin{array}{l}\text { EQUIP. } \\
\text { MENI } \\
=======\end{array}$ & $\begin{array}{c}S / C \\
0 H \& P \\
=======\end{array}$ & $\begin{aligned} & \text { IUIAL } \\
& \text { OOLIARS } \\
&======-\end{aligned}$ \\
\hline 500 & .290000 & - & $\begin{array}{l}\text { REFUSE SIATIC THICKENER } \\
\text { UNDERFL OW PUMP }\end{array}$ & 1 & $E A$ & 64 & 2499 & 337 & 0 & 0 & 13928 & 34 & 10798 \\
\hline 500 & .315100 & . & $\begin{array}{l}\text { GOYNE PUMP } \\
\text { REFUSE CONVEYOR } \\
\text { BY OTHERS NOI PART OF THIS } \\
\text { CONTRACT }\end{array}$ & 1 & EA & 0 & 0 & 0 & 0 & 0 & 0 & 0 & 0 \\
\hline 500 & .320100 & - & $\begin{array}{l}\text { HEAVY MEDIA CYCLONE SUMP } \\
\text { PLATEWORK WT. } 2500 \#\end{array}$ & 11 & EA & 32 & 1243 & 274 & 4240 & 0 & 0 & 451 & 6208 \\
\hline 500 & .325000 & - & $\begin{array}{l}\text { HEAVY MEDIA CYCLONE PUMPI } \\
\text { GOYNE PUMP }\end{array}$ & 1 & EA & 32 & 1249 & 168 & 0 & 0 & 16797 & 17 & 18231 \\
\hline 500 & .330000 & . & $\begin{array}{l}\text { HEAVY MEDIA CYCLONE } \\
\text { KREBS } 20 " \text { DIAMEIER CERAMIC }\end{array}$ & 1 & $E A$ & 40 & 1554 & 343 & 0 & 0 & 39697 & 34 & 41628 \\
\hline 500 & .330100 & . & $\begin{array}{l}\text { HEAVY MEDIA CYCLONE OVERFLOW } \\
\text { BOX PLAIEWORK WT. } 2000 \#\end{array}$ & 1 & EA & 32 & 1243 & 274 & 3180 & 0 & 39697 & 345 & 44739 \\
\hline 500 & .335000 & . & $\begin{array}{l}\text { MIDS SIEVE BEND } \\
3 \text { 'WIDE,80"R, } 60, .5 M M, 3 / 32 \text { ISO }\end{array}$ & 1 & $E A$ & 48 & 1865 & 411 & 0 & 0 & 4876 & 41 & 7143 \\
\hline 500 & .335100 & - & $\begin{array}{l}\text { MIDS SIEVE BEND DISCHARGE } \\
\text { CHUIE PILAIEHORK WI. } 1000 \#\end{array}$ & 1 & EA & 24 & 933 & 206 & 1590 & 0 & 0 & 180 & 2909 \\
\hline 500 & .340000 & . & $\begin{array}{l}\text { MIDS ORAIN AND RINSE SCREEN } \\
\text { TABOR } 4 \text { 'X16' SO VIBRATING, } \\
\text { HORIZONTAL. }\end{array}$ & 1 & $E A$ & 160 & 6217 & 1371 & 0 & 0 & 23320 & 137 & 31045 \\
\hline 500 & .340100 & . & $\begin{array}{l}\text { MIDS DRAIN AND RINSE SCREEN } \\
\text { UNDERFLOW PAN PLATEWORK } \\
\text { WT. } 3500 \#\end{array}$ & 1 & $E A$ & 160 & 6217 & 1371 & 6360 & 0 & 0 & 773 & $14 / 21$ \\
\hline 500 & .340200 & - & $\begin{array}{l}\text { MIDS DRAIN AND RINSE SCREEN } \\
\text { DISCHARGE CHUTE PLATEWORK } \\
\text { WT. } 2000 \#\end{array}$ & 1 & $E A$ & 32 & 1243 & 274 & 3180 & 0 & 0 & 345 & 5042 \\
\hline 500 & .340300 & . & $\begin{array}{l}\text { MIDLS DESLIME DISCHARGE CHUIE } \\
\text { PLAIEWORK WT. } 1600 \#\end{array}$ & 1 & $E A$ & 32 & 1243 & 274 & 2650 & 0 & 0 & 292 & 4459 \\
\hline 500 & .345000 & . & $\begin{array}{l}\text { REFUSE SIEVE BEND } \\
3 \text { 'WIDE, } 40 " R, 60, .5 M M, 3 / 32 \text { ISO }\end{array}$ & 1 & EA & 64 & 2487 & 549 & 0 & 0 & 2332 & 55 & 5423 \\
\hline 500 & .345100 & & $\begin{array}{l}\text { REFUSE SIEVE BEND DISCHARGE } \\
\text { CHUTE PLATEWORK WT. } 1000 \#\end{array}$ & 18 & $E A$ & 24 & 933 & 206 & 0 & 0 & 0 & 21 & 1160 \\
\hline 500 & .350000 & - & $\begin{array}{l}\text { REFUSE DRAIN AND RINSE SCREEN } \\
\text { TABOR \& } 416 \text { S SD VIBRATING } \\
\text { NORIZOHTAL }\end{array}$ & 1 & EA & 160 & 6217 & 1371 & 0 & 0 & 23320 & 137 & 31045 \\
\hline 500 & .350100 & . & $\begin{array}{l}\text { REFUSE DRAIN AND RINSE SCREEN } \\
\text { UNDERFLOW PAN PLATEWORK } \\
\text { WT. } 2200 \%\end{array}$ & 1 & $E A$ & 160 & 6217 & 1371 & 3710 & 0 & 0 & 508 & 11806 \\
\hline 500 & .350200 & - & $\begin{array}{l}\text { REFUSE DRAIN AND RINSE SCREEN } \\
\text { DISCHARGE CHUTE PLATEWORK } \\
\text { WI. } 1200 \%\end{array}$ & 1 & $E A$ & 24 & 933 & 206 & 2120 & 0 & 0 & 233 & 3492 \\
\hline 0 & .350300 & . & $\begin{array}{l}\text { REFUSE DRAIN AND RINSE SCREEN } \\
\text { OISCHARGE CHUTE TO REFUSE } \\
\text { CENTRIFUGE DRIVE WT. } 300 \mathrm{H}\end{array}$ & 1 & EA & 24 & 933 & 206 & 636 & 0 & 0 & 84 & 1850 \\
\hline
\end{tabular}


ICF KAISER ENGINEERS, INC. DEPARTMENI OF ENERGY JOB NO. B8107-250-00
ICF KAISER INLIIHEIRS IMIERACIIVE ESIIMAIING 20 IPH CIEAN COAI SEMI WORKS CONCEPIUAL DESIGN GENERAI ESTIMATE FOR REFERANCE
HALL 10

DAIE: $07113 / 44$ 15:21

REPORT DI - ESTIMAIE DETAIL BY FACILITY

BY -WORK BREAKDOWH-..
FACIL.STANDRD. WKPKG DESCRIPIION QUANTIIY MANHOURS LABOR

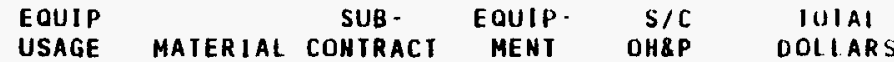
$== \pm== \pm= \pm==\approx== \pm==== \pm=$ MATERIAL COHTRACT MENT OH\&P DOLIARS

500.350400 REFUSE DRAIN AND RINSE SCREEN DISCHARGE CHUTE IO REFIJSE CONVEYOR HT 1000 R

500.360000 . HEAVY MEDIA CONTROL BOX

PLATEWORK WT. $1000 \#$

500365000 . HEAVY MEDIA SENSOR BOX

PLATEWORK WT. $400 \mathrm{H}$

PLATEWORK WT 2200

GOYNE PUMP

500.380000 . MAGNEIIC SEPARATOR

ERIE2 36" DIAMETER X 9'WIDE

MAGNEIIC SEOARATOR TAIIIINGS

CHUTE AND CONCENTRATE CHUTE

PLATEWORK WT. $2600 \#$

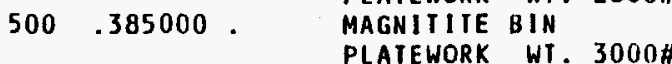

500.385100 . MAGNITIIE BIN DUST COLIEC.IOR

MAGNITITE BIN DUST COL

MAGRITITE ROIARY VALVE

MAGNITITE ROIARY VALVE

500.390000

ANORIII SPROUT-BAUER

500.390100 .

MAGNETIC ROTARY VALVE

DISCHARGe CHUTE PLATEHORK

WT. $60 \mathrm{~W}$

500.395000 INSTRUMENT AIR COMPRESSOR

AIRTEC

500.395100 . INSIRUMENT AIR COMPRESSOR

DRYER AIRTEC

500.395200 . INSTRUMENT AIR COMPRESSOR

PREFILTERS AIRTEC

POUIPHENT IN 305000

INSTRUMENT AIR COMPRESSOR

AFTERFILIERS AIRTEC

$\begin{array}{lll} & \text { AFTERFITIERS AIRTEC } \\ 500 & .398000 . & \text { EOUIPMENT IN } 395000 \\ \text { PI.AHT AND COLUMN AIR }\end{array}$

COMPRESSOR AIRTEC

PLANT AND COLUMN AIR.

COMPRESSOR-PREFILTERS AIRIEC

EOUIPMENT IN 398000

PLANT AND COLUMN AIR

COMPRESSOR AFTERFILTERS

EQUIPMENT IN 398000

$500 \quad .400000$

PL

\begin{tabular}{|c|c|c|c|c|c|c|c|c|}
\hline $1 E A$ & 24 & 933 & 206 & 1590 & 0 & 0 & 180 & 2900 \\
\hline $1 E A$ & 32 & 1243 & 274 & 1855 & 0 & 0 & 213 & 3585 \\
\hline $1 \mathrm{EA}$ & 16 & 622 & 137 & 795 & 0 & 0 & 93 & 1647 \\
\hline $1 \mathrm{EA}$ & 32 & 1243 & 274 & 4240 & 0 & 0 & 451 & 62018 \\
\hline $1 E A$ & 64 & 2499 & 337 & 0 & 0 & 11546 & 34 & 1.4410 \\
\hline $1 E A$ & 64 & 2487 & 549 & 0 & 0 & 16960 & 55 & 201131 \\
\hline$I E A$ & 48 & 1865 & 411 & 4240 & 0 & 0 & 465 & 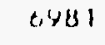 \\
\hline $1 E A$ & 32 & 1243 & 274 & 5300 & 0 & $u$ & 537 & is/s \\
\hline $1 \mathrm{EA}$ & 32 & 1243 & 274 & 0 & 0 & b379 & 27 & 4123 \\
\hline $1 E A$ & 24 & 933 & 206 & 0 & 0 & 2849 & 21 & 4054 \\
\hline $1 \mathrm{EA}$ & 16 & 622 & 137 & 318 & 0 & 0 & 46 & 1123 \\
\hline $1 \mathrm{EA}$ & 64 & 2499 & 337 & 0 & 0 & 12036 & 34 & 14906 \\
\hline $1 \mathrm{EA}$ & 24 & 937 & 126 & 0 & 0 & 0 & 13 & 1076 \\
\hline $1 E A$ & 24 & 937 & 126 & 0 & 0 & 0 & 13 & 1016 \\
\hline $2 E A$ & 48 & 1874 & 253 & 0 & 0 & 0 & 25 & 2132 \\
\hline $1 E A$ & 64 & 2499 & 337 & 0 & 0 & 52391 & 34 & 55261 \\
\hline $1 \mathrm{EA}$ & 24 & 937 & 126 & 0 & 0 & 0 & 13 & 1076 \\
\hline 2 EA & 48 & 1874 & 253 & 0 & 0 & 0 & 25 & 2152 \\
\hline $1 E A$ & 0 & 0 & 0 & 0 & 0 & 0 & 0 & 0 \\
\hline
\end{tabular}


ICF KAISER ENGINEERS, INC. DEPARTMENT OF ENERGY JOB NO. $88107-250-00$
ICF KAISER ENGIMEERS INTERACIIVE ESTIMAIING

20 IPH CLEAN COAL SEMI-WORKS CONCEPTUAL DESIGN GENERAL ESTIMATE FOR REFERANCE

REPORT D1 - ESTIMATE DETAIL BY FACILITY
PAGE 11

DAIE: $07 / 13 / 94 \quad 13: 26$

\begin{tabular}{|c|c|c|c|c|c|c|c|c|c|c|c|c|}
\hline \multicolumn{3}{|c|}{$\begin{array}{l}\because \text { - WORK BREAKDOWN } . . \\
\text { FACIL.STANDRO. HKPKG } \\
=======z=========\end{array}$} & 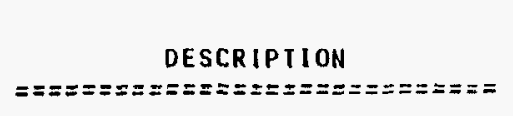 & $\begin{array}{l}\text { QUANIIIY } M \\
===\equiv=\Sigma==\equiv=\equiv\end{array}$ & $\begin{array}{l}\text { MANHOURS } \\
========\end{array}$ & $\begin{array}{l}\text { LABOR } \\
========\end{array}$ & $\begin{array}{l}\text { EQUIP } \\
\text { USAGE } \\
========\end{array}$ & $\begin{array}{l}\text { MA TER IAL } \\
=======\end{array}$ & $\begin{array}{l}\text { SUB. } \\
\text { CONTRACT } \\
=======\end{array}$ & $\begin{array}{l}\text { EQUIP. } \\
\text { MENI } \\
=======\end{array}$ & $\begin{array}{c}S / C \\
\text { OH\&P } \\
=======\end{array}$ & $\begin{array}{c}\text { IOIAL } \\
\text { DOILARS } \\
======-\end{array}$ \\
\hline 500 & .400100 & . & $\begin{array}{l}\text { FLOCCULANT SYSIEM ANIONIC } \\
\text { FEEDER MINEIEC. }\end{array}$ & $1 E A$ & 32 & 1243 & 274 & 0 & 0 & 1272 & 27 & 2810 \\
\hline 500 & .400200 & . & $\begin{array}{l}\text { FLOCCULANI SYSTEM ANIONIC } \\
\text { MIXER MINETEC }\end{array}$ & $1 \mathrm{EA}$ & 24 & 933 & 206 & 0 & 0 & 1590 & 21 & 275 \\
\hline 500 & .400300 & . & $\begin{array}{l}\text { FLOCCULANT SYSIEM ANIONIC } \\
\text { MIX TANK MINEIEC }\end{array}$ & $1 E A$ & 24 & 933 & 206 & 0 & .0 & 4240 & 21 & 5404 \\
\hline 500 & .400400 & - & $\begin{array}{l}\text { FLOCCULANT SYSIEM ANIONIC } \\
\text { HOLDING IANK MINETEC }\end{array}$ & $1 \mathrm{EA}$ & 32 & 1243 & 274 & 0 & 0 & 5300 & 27 & 6844 \\
\hline 500 & .400500 & - & $\begin{array}{l}\text { FLOCCULANT SYSIEM ANIONIC } \\
\text { METERING PUMP MINETEC }\end{array}$ & $2 \mathrm{EA}$ & 64 & 2499 & 337 & 0 & 0 & 3721 & 34 & 6591 \\
\hline 500 & .400600 & . & $\begin{array}{l}\text { FLOCCULANT SYSIEM CAIIONIC } \\
\text { HOLDING IANK MINETEC }\end{array}$ & $1 E A$ & 32 & 1243 & 274 & 0 & 0 & 6360 & 27 & 190. \\
\hline 500 & .400700 & . & $\begin{array}{l}\text { FLOCCULANT SYSTEM CATIONIC } \\
\text { METERING PUMP MINETEC }\end{array}$ & $2 \mathrm{EA}$ & 48 & 1874 & 253 & 0 & 0 & 3721 & 25 & 5813 \\
\hline 500 & .400800 & . & $\begin{array}{l}\text { FLOCCULANT SYSIEM SETTLING } \\
\text { RATE DETECTOR MINETEC }\end{array}$ & $2 E A$ & 32 & 1243 & 274 & 0 & 0 & 38775 & 27 & $\therefore 0314$ \\
\hline 500 & .400900 & . & $\begin{array}{l}\text { FLOCCULANI SYSIEM WATER } \\
\text { CLARIIY MEASUREMENT MINEIEC }\end{array}$ & $2 \mathrm{EA}$ & 32 & 1243 & 274 & 0 & 0 & 8946 & 27 & $10(4,4)$ \\
\hline 500 & .401000 & . & $\begin{array}{l}\text { FLOCCULANT SYSTEM PH REAGENT } \\
\text { PUMP MINETEC }\end{array}$ & $1 \mathrm{EA}$ & 24 & 937 & 126 & 0 & 0 & 1860 & 13 & 2436 \\
\hline 500 & .405000 & . & $\begin{array}{l}\text { REAGENT SYSTEM COMPLEIE } \\
\text { INCLUOING ITEMS } 405100 \text { THRU } \\
405800 \text { MINETEC }\end{array}$ & 1101 & 0 & 0 & 0 & 0 & 0 & 0 & 0 & \\
\hline 000 & .405100 & . & $\begin{array}{l}\text { REAGENT SYSTEM FROTHER BULK } \\
\text { STORAGE MINETEC }\end{array}$ & 1 EA & 32 & 1243 & 274 & 0 & 0 & 2385 & 27 & 3424 \\
\hline 500 & .405200 & - & $\begin{array}{l}\text { REAGENT SYSTEM FROIHER } \\
\text { IRANSFER PUMP MINETEC }\end{array}$ & $1 E A$ & 0 & 0 & 0 & 0 & 0 & 3721 & 0 & 3721 \\
\hline 00 & .405300 & - & $\begin{array}{l}\text { REAGENT SYSIEM FROTHER DAY } \\
\text { TANK MINETEC }\end{array}$ & $1 E A$ & 32 & 1243 & 274 & 0 & 0 & 3180 & 27 & 4724 \\
\hline 500 & .405400 & - & $\begin{array}{l}\text { REAGENT SYSIEM FROTHER } \\
\text { REAGENT PUMPS MINETEC }\end{array}$ & $4 E A$ & 96 & 3748 & 505 & 0 & 0 & 7441 & 51 & $11 / 45$ \\
\hline 500 & .405500 & . & $\begin{array}{l}\text { REAGENT SYSTEM COLLECTOR } \\
\text { BULK SIORAGE MINETEC }\end{array}$ & $1 \mathrm{EA}$ & 32 & 1243 & 274 & 0 & 0 & 2385 & 27 & 3429 \\
\hline 500 & .405600 & - & $\begin{array}{l}\text { REAGENI SYSTEM COLLECTOR } \\
\text { TRANSFER PUMPS MINETEC }\end{array}$ & 1 EA & 24 & 937 & 126 & 0 & 0 & 3721 & 13 & 4797 \\
\hline 500 & .405700 & . & $\begin{array}{l}\text { REAGENT SYSIEM COLLECTOR } \\
\text { DAY IANK MINETEC }\end{array}$ & $1 \mathrm{EA}$ & 32 & 1243 & 274 & 0 & 0 & 3180 & 27 & 4184 \\
\hline 500 & .405800 & - & $\begin{array}{l}\text { REAGENT SYSIEM COLLECTION } \\
\text { REAGENT FEEDERS MINETEC }\end{array}$ & $4 E A$ & 96 & 3730 & 823 & 0 & 0 & 7441 & 82 & 12076 \\
\hline 500 & .410000 & - & $\begin{array}{l}\text { OVERDENSE MEDIA SUMP } \\
\text { PLATEWDRK WT. } 2000 \#\end{array}$ & $1 \mathrm{EA}$ & 32 & 1243 & 274 & 3710 & 0 & 0 & 398 & 5625 \\
\hline 500 & .415000 & - & $\begin{array}{l}\text { OVERDENSE MEDIA PUMP } \\
\text { GOYNE PUMP }\end{array}$ & $1 E A$ & 32 & 1249 & 168 & o & 0 & 8678 & 17 & 10112 \\
\hline 00 & .420000 & - & $\begin{array}{l}\text { OVERDENSE MEDIA CONTROL BOX } \\
\text { PLATEWORK WT. } 1000 \mathrm{H}\end{array}$ & $1 \mathrm{EA}$ & 32 & 1243 & 274 & 1590 & 0 & 0 & 186 & 3243 \\
\hline
\end{tabular}


ICF KAISER ENGINEERS, INC. DEPARTMENT OF ENERGY JOB NO. $88107-250 \cdot 00$
ICF KAISER ENGINEERS INIERACIIVE ESIIMAIING

20 IPII CLEAN COAL SEMI WORKS CONCEPIUAL DESIGN GENERAL ESTIMAIE FOR REFERANCE

REPORT D1 - ESIIMAIE DETAIL BY FACILITY
PAGE 12

DAIE : $07 / 13 / 4413: 21$

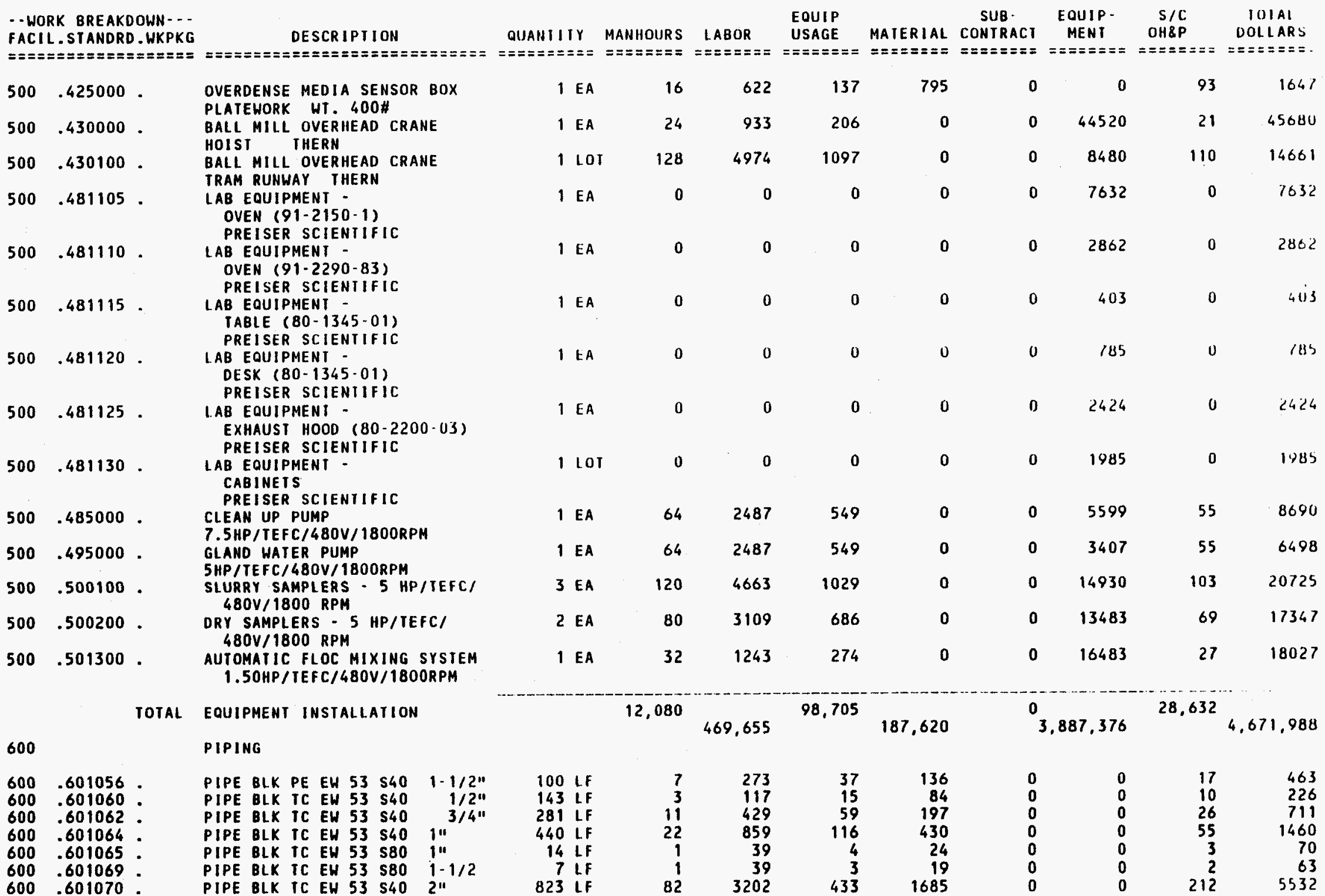


ICF KAISER ENGINEERS, INC. DEPARTMENT OF ENERGY JOB NO. 88107-250-00
ICF KAISER ENGINEERS INIERACIIVE ESIIMAIING 20 TPII CIEAN COAL SEMI WORKS CONCEPTUAL DESIGN GENERAL ESTIMAIE FOR REFERANCE

REPORT D1 - ESIIMAIE DETAIL BY FACILITY
PAGE 13

BY

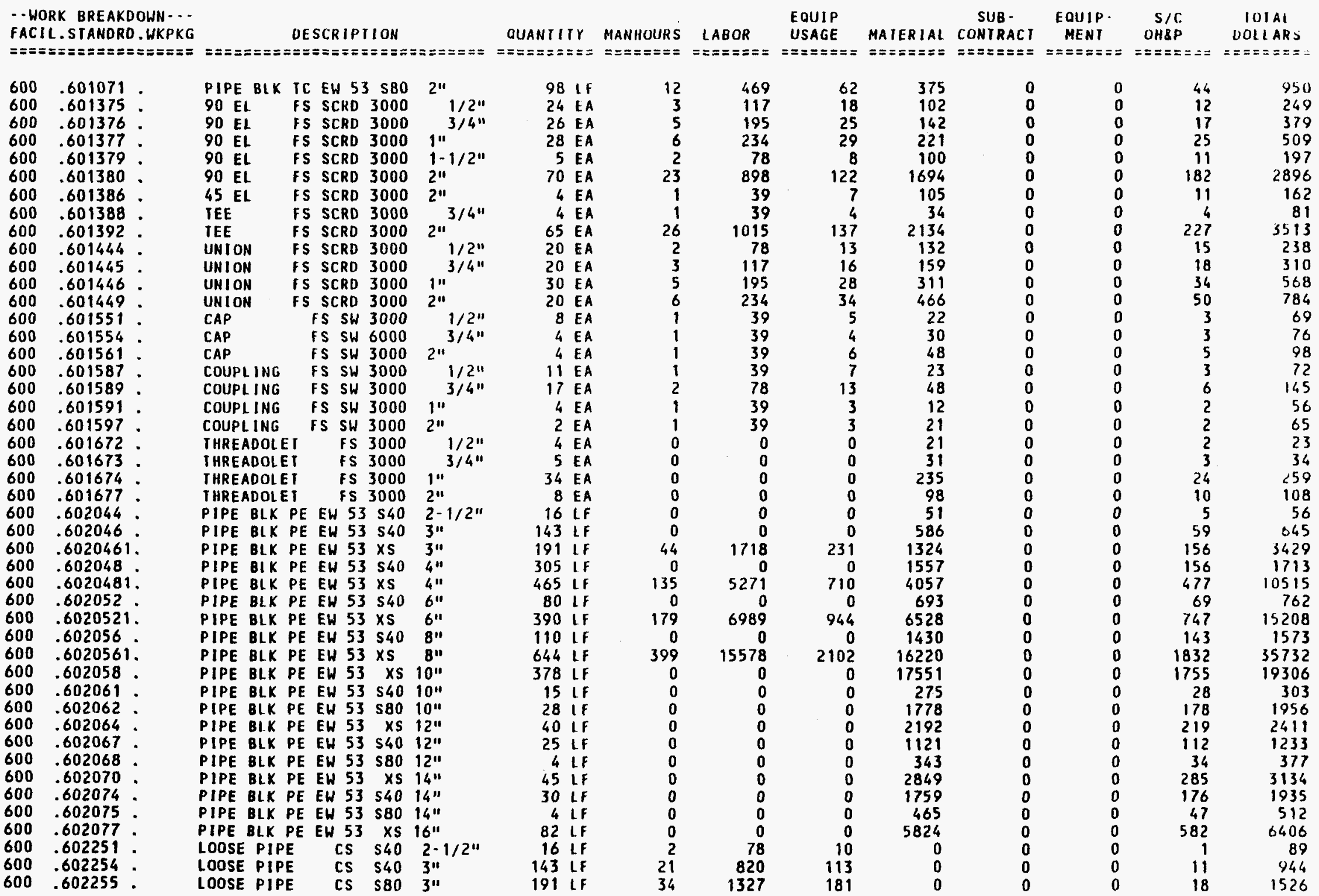


ICF KAISER ENGINEERS, INC. DEPAR IMENI OF ENERGY JOB NO. B8107-250-00
ICF KAISER ENGINEERS INIERACIIVE ESTIMAIING 20 IPII CIEAN COAL SEMI-WORKS CONCEPTUAL DESIGN GENERAL ESTIMATE FOR REFERANCE

REPORT D1 - ESTIMAIE DETAIL BY FACILIIY
PACE 14

DAIE : 07/15/4: is:21

BY
- -WORK BREAKDOWN -..
FACIL.STAHORD. HKPKG

600.602257 . LOOSE PIPE CS $540 \quad 4 "$

$600.602250^{\circ}$. $\quad$ LOOSE PIPE CS S80 411

$600.602263:$ LOOSE PIPE CS S40 6"

600.602264 . LODSE PIPE CS S80 6"

600.602268 . LOOSE PIPE CS S40 811

600.602270 . LOOSE PIPE CS 580 8"

600.602272 . LOOSE PIPE CS XS 10"

$600602275^{\circ}$. LODS PIPE CS $540^{\circ}$

$600.60220^{\circ}$ LODE PIPE CS S40 10"

$600.602280^{\circ}$. LOOSE PIPE CS XS $12^{\prime \prime}$

$600^{\circ} .602283^{\circ}$ L LOOSE PIPE CS S40 12"

$600.6022855^{\circ}$ LOOSE PIPE CS SBO 12"

$600.602288^{\circ}$. LOSE PIPE CS XS $14 \mathrm{n}$

$600.002292^{\circ}$. LOOSE PIPE CS $54014^{\prime \prime}$

$600.602294^{\circ}$ LODS PIPE CS $58014 "$

$600.602296^{\circ}$ LODSE PIPE CS XS 16"1

600.602408 . 90 LR BUTTW. CS $5402 \cdot 1 / 2^{4}$

600.602411 . 90 LR BUITW. CS S40 3"

600.602412 . 90 LR BUTTH. CS S80 3"

600.602414 . 90 LR BUITH. CS S40 4"

600.602420

600.602421 .

600.602425 .

.602427 :

.602432 .

.602433 .

.602437.

.602438
.602442

.602488 :

.602501 .

.602506 .

.602508 .

.602512

.602537

.602538 .

.602540

.602546

.602547
.602550

.602550
.602551

.602553

.602635 .

.602638

.602644 .

90 LR BUIIH. CS S80 4"

90 IR BUTIH. CS S40 6"

90 IR BUTTH. CS S80 6"

90 IR BUTIW. CS 540 B"

90 LR BUTIW. CS S80 8"

90 LR BUTTH. CS XS 10"

90 IR BUTTH. CS STO 12"

90 IR BUTIN. CS XS 12"

90 LR OUTH. CS XS

90 LR BUTW. CS STO

90 LR BUTIH. CS XS 16"

$45 \mathrm{EL}$ BUTTH. CS $\$ 40$ 3"

$45 \mathrm{EL}$ BUTTH. CS 540 8"

45 EL BUTTH. CS $54010^{\prime \prime}$

$45 \mathrm{EL}$ BUTIH. CS STD. 121

$45 \mathrm{EL}$ BUITH. CS STD $14 "$

IEE DUITH. CS S40 3 "

TEE BUTH. CS S40 3"

TEE BUITH. CS S40 4 "

TEE BUTH. CS S40 4"

TEE BUTHW. CS S40 6"

TEE QUTH. CS SBO 6"

TEE BUTHW. CS S40

TEE BUTTW. CS SOO

TEE BUTTH. CS XS 10"

CON RED BUTTW CS S40 3 "

CON RED BUTIH CS 540 4"
CON RED BUTIH CS 540 6"

QIIANIIIY MANIIOURS LABOR

EQUIP

SUB

SUB - EQUIP

S/C

IOIAI

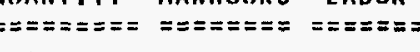

$=====$

$\begin{array}{rl}305 & \text { LF } \\ 485 & \text { LF } \\ 80 & \text { IF } \\ 390 & \text { LF } \\ 110 & \text { LF } \\ 672 & \text { LF } \\ 378 & \text { LF } \\ 15 & \text { I.F } \\ 40 & \text { IF } \\ 25 & \text { IF } \\ 4 & \text { IIF } \\ 45 & \text { I.F } \\ 30 & \text { I F } \\ 4 & \text { I.F } \\ 82 & \text { IF } \\ 8 & E A \\ 15 & E A \\ 12 & E A \\ 19 & E A \\ 32 & E A \\ 12 & E A \\ 19 & E A \\ 1 & E A \\ 52 & E A \\ 30 & E A \\ 3 & E A \\ 3 & E A \\ 1 & E A \\ 1 & E A \\ 2 & E A \\ 5 & E A \\ 25 & E A \\ 5 & E A \\ 1 & E A \\ 4 & E A \\ 4 & E A \\ 1 & E A \\ 11 & E A \\ 2 & E A \\ 3 & E A \\ 1 & E A \\ 2 & E A \\ 1 & E A \\ 3 & E A \\ 5 & E A \\ 1 & E A \\ \end{array}$

$\begin{array}{rrr}61 & 2382 & 321 \\ 112 & 4373 & 587 \\ 23 & 898 & 122 \\ 144 & 5622 & 760 \\ 43 & 1679 & 226 \\ 329 & 12845 & 1733 \\ 231 & 9019 & 1213 \\ 7 & 273 & 39 \\ 29 & 1132 & 154 \\ 16 & 625 & 83 \\ 4 & 156 & 21 \\ 38 & 1484 & 201 \\ 23 & 898 & 123 \\ 5 & 195 & 27 \\ 80 & 3123 & 423 \\ 0 & 0 & 0 \\ 0 & 0 & 0 \\ 0 & 0 & 0 \\ 0 & 0 & 0 \\ 0 & 0 & 0 \\ 0 & 0 & 0 \\ 0 & 0 & 0 \\ 0 & 0 & 0 \\ 0 & 0 & 0 \\ 0 & 0 & 0 \\ 0 & 0 & 0 \\ 0 & 0 & 0 \\ 0 & 0 & 0 \\ 0 & 0 & 0 \\ 0 & 0 & 0 \\ 0 & 0 & 0 \\ 0 & 0 & 0 \\ 0 & 0 & 0 \\ 0 & 0 & 0 \\ 0 & 0 & 0 \\ 0 & 0 & 0 \\ 0 & 0 & 0 \\ 0 & 0 & 0 \\ 0 & 0 & 0 \\ 0 & 0 & 0 \\ 0 & 0 & 0 \\ 0 & 0 & 0 \\ 0 & 0 & 0 \\ 0 & 0 & 0 \\ 0 & 0 & 0 \\ 0 & 0 & 0 \\ & & \end{array}$

0
0
0
0
0
0
0
0
0
0
0
0
0
0
0
62
115
136
242
598
374
883
58
4508
4648
446
655
201
271
725
33
1017
367
104
563
68
23
259
85
181
79
244
198
21
47
19

$\begin{array}{rr}32 & 2735 \\ 59 & 5019 \\ 12 & 1032 \\ 76 & 6458 \\ 23 & 1928 \\ 173 & 14751 \\ 121 & 10353 \\ 4 & 316 \\ 15 & 1301 \\ 8 & 716 \\ 2 & 179 \\ 20 & 1705 \\ 12 & 1033 \\ 3 & 225 \\ 42 & 3588 \\ 6 & 68 \\ 12 & 127 \\ 14 & 150 \\ 24 & 266 \\ 60 & 658 \\ 37 & 411 \\ 88 & 971 \\ 6 & 64 \\ 451 & 4959 \\ 465 & 5113 \\ 45 & 491 \\ 66 & 721 \\ 20 & 221 \\ 27 & 298 \\ 73 & 798 \\ 3 & 36 \\ 102 & 1119 \\ 37 & 404 \\ 10 & 114 \\ 56 & 619 \\ 7 & 75 \\ 2 & 25 \\ 26 & 285 \\ 9 & 94 \\ 18 & 199 \\ 8 & 87 \\ 24 & 268 \\ 20 & 218 \\ 2 & 23 \\ 5 & 52 \\ 2 & 21 \\ & \\ 14 & \end{array}$


ICF KAISER ENGINEERS, INC. DEPARTMENY OF ENERGY JOB NO. BB107-250-00
ICF KAISER ENGINEERS INIERACIIVE ESIIMAIING 20 IPI CIEAN COAL SEMI WORKS CONCEPIUAL DESIGN GENERAL ESTIMATE FOR REFERANCE

REPORI DI. ESIIMAIE DETAII BY FACILIIY
PACE 15

DAIE: $07 / 15 / 94$ is: 21 BY

- WORK BREAKDOWN-..DESCRIPIION QUANTITY MANHOURS LABOR EQUIP $\begin{array}{lll}\text { SUB - EQUIP. } & \text { S/C } \\ \text { OHEP } & \text { CONTRACI MENT }\end{array}$ TOIAL FACIL. STANDRD. WKPKG CON RED BUTTW CS S80 6" CON RED BUTIW CS S40 B"

$600 \quad .602645$ CON RED BUTTH CS XS 10" CON RED BUTTH CS S40 10" CON RED BUTTH CS STO 12" CON RED BUTIH CS XS 12" CON RED BUTTW CS XS 14" CAP BUTTHELD CS 540 3" CAP BUTTHELD CS 540 4" CAP BUITHELD CS S40 6" CAP BUITHELO CS S40 10" WELDOLEI CS STD 3 " SO FLANGE CS A181 150 2.1/2" SO FIANGE CS A181 150 3" SO FLAHGE CS A181 150 4" SO FIAIIGE CS A1B1 150 "6" SO FIANGE CS A1B1 150 " SO FLANGE CS A1BI 150 8 SO FIANGE CS AIBI 150 10" SO FLANGE CS A 181 $15012^{\prime \prime}$ SO FLANGE CS A $18115014^{\prime \prime}$ SO FLANGE CS AI8I 150 16" THRD. FLG CS A181 $150 \quad 2-1 / 2$ THRD. FLG CS A181 150 3" BLIND FLG CS A181 150 3" BLIND FLG CS A181 150 4" BLIND FLG CS A18I 150 6" BLIND FLG CS A181 $15016 "$ FIELD IT BW CS $540 \quad 2-1 / 2 "$ FIELD JI BW CS S40 3" FIELD JI BW CS SBO 3" FIELD JT BW CS S40 4" FIELD JI BW CS S40 4" FIELL JT BW CS 580 6" FIELD JT BW CS S80 6" FIELD JT BH CS S40 8" FIELD JT BW CS SBO 8" FIELD JT BW CS XS 10" FIELD JT BH CS S40 10" FIELD JT BW CS STO 12" FIELD JT BH CS XS 12" FIELD JI BW CS STD 14" FIELD JI OH CS XS 14" FIELD JI BH CS XS 16" IUBING COPPER $K \quad 3 / 8^{\prime \prime}$ IUBING COPPER $\begin{array}{ll}K & 3 / 8^{\prime \prime} \\ K & 1 / 2\end{array}$

CPLG VICT + BOLIUP STB 4"

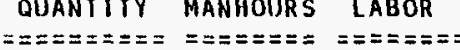

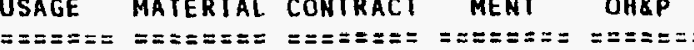
$=====$

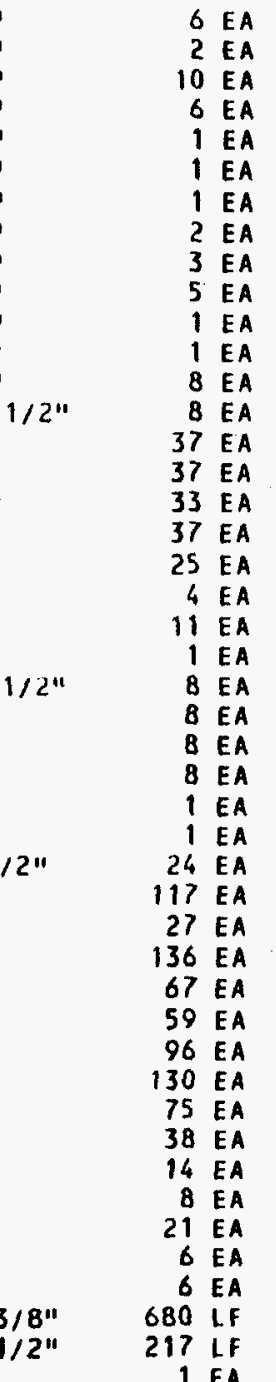

$\begin{array}{rr}0 & 0 \\ 0 & 0 \\ 0 & 0 \\ 0 & 0 \\ 0 & 0 \\ 0 & 0 \\ 0 & 0 \\ 0 & 0 \\ 0 & 0 \\ 0 & 0 \\ 0 & 0 \\ 0 & 0 \\ 0 & 0 \\ 0 & 0 \\ 0 & 0 \\ 0 & 0 \\ 0 & 0 \\ 0 & 0 \\ 0 & 0 \\ 0 & 0 \\ 0 & 0 \\ 0 & 0 \\ 2 & 78 \\ 2 & 78 \\ 2 & 78 \\ 3 & 117 \\ 1 & 39 \\ 1 & 39 \\ 22 & 859 \\ 129 & 5037 \\ 37 & 1445 \\ 199 & 7770 \\ 147 & 5739 \\ 162 & 6325 \\ 281 & 10971 \\ 476 & 18585 \\ 344 & 13431 \\ 139 & 5427 \\ 61 & 2382 \\ 44 & 1718 \\ 115 & 4490 \\ 42 & 1640 \\ 51 & 1991 \\ 7 & 273 \\ 4 & 156 \\ 1 & 39\end{array}$

0
0
0
0
0
0
0
0
0
0
0
0
0
0
0
0
0
0
0
0
0
0
10
12
12
16
3
8
116
678
196
1045
776
852
1481
2508
1808
733
323
230
605
220
269
36
23
4
0


ICF KAISER ENGINEERS, INC. DEPARIMENT OF ENERGY JOB NO. $88107-250-00$
ICF KAISER ENGINEERS INIERACIIVE ESIIMATING

20 IPH CLEAN COAL SEMI-HORKS CONCEPTUAL DESIGN GENERAL ESTIMAIE FOR REFERANCE
PAGE 16

DAIE: $07 / 13 / 4415: 21$

REPORT D1 - ESIIMAIE DETAIL BY FACILITY

\begin{tabular}{|c|c|c|c|c|c|c|c|c|c|c|c|c|c|}
\hline \multicolumn{3}{|c|}{$\begin{array}{l}\text { - WORK BREAKDOWN-... } \\
\text { FACIL. SIANDRD. WKPKG } \\
==============\end{array}$} & 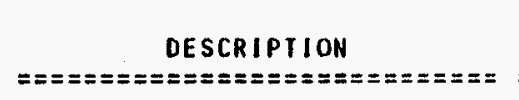 & $\begin{array}{l}\text { QUANIII } \\
========\end{array}$ & & $\begin{array}{l}\text { MANHOURS } \\
========\end{array}$ & $\begin{array}{l}\qquad A B O R \\
=======\end{array}$ & $\begin{array}{l}\text { EQUIP } \\
\text { USAGE } \\
=======\end{array}$ & $\begin{array}{l}\text { MAIER IAL } \\
========\end{array}$ & $\begin{array}{l}\text { SUB. } \\
\text { CONTRACI } \\
=======\end{array}$ & $\begin{array}{l}\text { EQUIP. } \\
\text { MENI } \\
=======\end{array}$ & $\begin{array}{c}S / C \\
\text { OHBP } \\
========\end{array}$ & $\begin{array}{c}\text { IOIAI } \\
\text { DOLLARS } \\
=======\end{array}$ \\
\hline $\begin{array}{l}600 \\
600 \\
600 \\
600 \\
600\end{array}$ & $\begin{array}{l}.607778 \\
.607779 \\
.607780 \\
.607781 \\
.651342\end{array}$ & : & 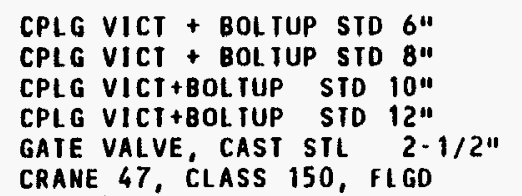 & $\begin{array}{l}1 \\
4 \\
1 \\
2 \\
8\end{array}$ & $\begin{array}{l}E A \\
E A \\
E A \\
E A \\
E A\end{array}$ & $\begin{array}{l}1 \\
4 \\
1 \\
3 \\
8\end{array}$ & $\begin{array}{r}39 \\
156 \\
39 \\
117 \\
312\end{array}$ & $\begin{array}{r}5 \\
22 \\
6 \\
14 \\
41\end{array}$ & $\begin{array}{r}21 \\
139 \\
49 \\
112 \\
3821\end{array}$ & $\begin{array}{l}0 \\
0 \\
0 \\
0 \\
0\end{array}$ & $\begin{array}{l}0 \\
0 \\
0 \\
0 \\
0\end{array}$ & $\begin{array}{r}3 \\
16 \\
6 \\
13 \\
386\end{array}$ & $\begin{array}{r}60 \\
333 \\
100 \\
256 \\
4560\end{array}$ \\
\hline 600 & .651343 & . & $\begin{array}{l}\text { GAIE VALVE, CAST STL } 3 " \\
\text { CRANE } 47, \text { CLASS 150, FLGD }\end{array}$ & 21 & EA & 31 & 1210 & 161 & 10030 & 0 & 0 & 1019 & 12420 \\
\hline 600 & .651344 & . & $\begin{array}{l}\text { GATE VALVE, CAST STL } 4 " \\
\text { CRANE } 47, \text { CLASS } 150 \text {, FIGD }\end{array}$ & 13 & EA & 27 & 1054 & 142 & 7970 & 0 & 0 & 811 & 9971 \\
\hline 600 & .651347 & . & $\begin{array}{l}\text { GAIE VALVE, CAST STL } 810 \\
\text { CRANE } 47, \text { CLASS } 150, \text { FIGD }\end{array}$ & 1 & $E A$ & 3 & 117 & 18 & 1527 & 0 & 0 & 135 & $181 \%$ \\
\hline 600 & .652103 & . & $\begin{array}{l}\text { GATE V VOGI FS } 60011 \\
\text { SW-12111 }\end{array}$ & 3 & $E A$ & 1 & 39 & 8 & 137 & 0 & 0 & 15 & 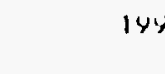 \\
\hline 600 & .652106 & . & $\begin{array}{l}\text { GAIE V VOGI FS } 600 \quad 21 " \\
\text { SW-12111 }\end{array}$ & 22 & $E A$ & 22 & 859 & 113 & 2463 & 0 & 0 & 258 & 3645 \\
\hline 600 & .652283 & . & $\begin{array}{l}\text { BALL VALVE, CS } \\
\text { JAMESBURY AZ236II } \\
\text { SCREWED ENDS, } 2000 \text { PSI }\end{array}$ & 68 & $E A$ & 28 & 1093 & 147 & 3822 & 0 & 0 & 397 & 5454 \\
\hline 600 & .652284 & . & $\begin{array}{l}\text { BALL VALVE, CS } \\
\text { JAME SBURY A22361T } \\
\text { SCREWED ENDS, } 2000 \text { PSI }\end{array}$ & 15 & $E A$ & 7 & 273 & 36 & 1132 & 0 & 0 & 117 & 1958 \\
\hline 600 & .652285 & - & $\begin{array}{l}\text { BALL VALVE, CS } \\
\text { JAMESBURY A2236IT } \\
\text { SCREWED ENDS, } 2000 \text { PSI }\end{array}$ & 50 & EA & 24 & 937 & 129 & 4889 & 0 & 0 & 502 & 0,438 \\
\hline 600 & .653020 & . & $\begin{array}{l}\text { GATE VALVE, BRONZE } 1-1 / 2 " \\
\text { CRANE } 1324, \text { CLASS } 150, \mathrm{SJ}\end{array}$ & 2 & $E A$ & 1 & 39 & 6 & 66 & 0 & 0 & 7 & 118 \\
\hline 600 & .653378 & . & $\begin{array}{l}\text { CHECK VAL VE, BRONZE } \\
\text { CRANE } 36, \text { CLASS } 200 \mathrm{H}, \text { IHD }\end{array}$ & 1 & $E A$ & 1 & 39 & 4 & 97 & 0 & 0 & 10 & 130 \\
\hline 600 & .653497 & - & $\begin{array}{l}\text { GATE VALVE, BRONZE } \\
\text { CRANE } 431 \text {, CLASS 150, THD }\end{array}$ & 4 & EA & 6 & 234 & 31 & 715 & 0 & 0 & 75 & luss \\
\hline 600 & .653716 & - & $\begin{array}{l}\text { CHECK VALVE, BRONZE } \\
\text { CRANE } 36, \text { CLASS 200, THD }\end{array}$ & 1 & EA & 1 & 39 & 8 & 295 & 0 & 0 & 30 & 372 \\
\hline 600 & .655680 & . & $\begin{array}{l}\text { KNIFE GATE SS } 1504 " \\
\text { DEZURIK } 824 \text { W/ HANDWHEEL OPER } \\
304 \text { SS WETIED PARTS, WAFER }\end{array}$ & 3 & $E A$ & 5 & 195 & 26 & 1084 & 0 & 0 & 111 & 1416 \\
\hline 600 & .655681 & . & $\begin{array}{l}\text { KNIFE GAIE SS } 150 \text { \%" } \\
\text { DEZURIK } 824 \text { W/ HANDWHEEL OPER } \\
304 \text { SS WETTED PARTS, WAFER }\end{array}$ & $4 E$ & $E A$ & 9 & 351 & 48 & 1772 & 0 & 0 & 182 & 2353 \\
\hline 600 & .655682 & - & $\begin{array}{l}\text { KNIFE GATE CI } 1508 " \\
\text { DEZURIK } 824 \text { W/ HANDWHEEL OPER } \\
304 \text { SS WETIED PARTS, WAFER }\end{array}$ & 26 & EA & 5 & 195 & 29 & 1208 & 0 & 0 & 124 & 1556 \\
\hline 600 & .655684 & & $\begin{array}{l}\text { KNIFE GATE CI } 150,12 " \\
\text { OEZURIK } 824 \text { W/ HANDWHEEL OPER } \\
304 \text { SS WETIED PARTS, WAFER }\end{array}$ & $4 \mathrm{E}$ & EA & 13 & 508 & 68 & 4181 & 0 & 0 & 425 & 5182 \\
\hline
\end{tabular}


ICF KAISER ENGINEERS, INC. DEPARTMENT OF ENERGY JOB NO. 88107-250-00
ICF KAISER ENGINEERS INIERACIIVE ESIIIMAIING 20 IPII CLEAN COAL SEMI-WORKS CONCEPIUAL DESIGN GENERAL ESTIMAIE FOR REFERANCE
PAGE 17

DAIE : $07 / 13 / 94,13: 26$

REPORI D1 - ESIIIMAIE DETAIL BY FACILITY

- WORK BREAKDOWN -..
FACIL.STANDRD. WKPKG
$==z============= \pm$

\begin{abstract}
$600 \quad .655685$.
\end{abstract}
$\begin{array}{ll}600 & .686001 . \\ 600 & .686002:\end{array}$

600.686003 .

$\begin{array}{ll}600 & .686004 \\ 600 & .686007\end{array}$

$\begin{array}{ll}600 & .686007 \\ 600 & .686008\end{array}$

600.686009 :

600.686011 .

600.686012 .

600.686013 .

600.686014 .

600.686015 .
KNIFE GATE CI 15014 " DEZURIK 824 W/ BEVEL GEAR OPR 304 SS WETTED PARTS, WAFER IEST \& CLEAN TEST \&LEAN IEST \&LEAN TESI \& CLEAN IESI \& CLEAN IEST \& CLEAN IESI \& CLEAN IESI \& CLEAN IEST CLEAN IESI \& CLEAN IESI \& CLEAN IESI \& CLEAN IEST \& CLEAN

$1 / 2 "$
$3 / 4 "$
$1 "$
$1-1 / 4 "$
$2 \cdot 1 / 2 "$
311
411
$6 "$
$8 "$
$10^{\prime \prime}$
$12 "$
$14 "$
$16^{\prime \prime}$

TOIAL PIPING

675

675.605555 .

675.605563

675.605568 .

675.605572 :

675.605577 .

675.605582 .

.605603

.605604 .

.605605

.605607

.605607

.605608 .

605617

.605618

605620 .

.605621

.605622

.605659

.605660 .

.605661

.605662

.606020

.606021
.606022

\section{MECHANICAL}

TUBING COPPER

IUBING COPPER

IUBING COPPER

TUBING COPPER

TUBING COPPER

TUBING COPPER

90 EL COPPER SOLDER 1/2"

90 EL COPPER SOLDER

$90 \mathrm{EL}$ COPPER SOLDER $1 " 1 / 4$

$90 \mathrm{EL}$ COPPER SOLDER $1-1 / 2 "$

90 EL COPPER SOLDER $2 " 1$

TEE COPPER SOLDER 1/2"

TEE COPPER SOLOER 3/4"

TEE COPPER SOLDER

IEE COPPER SOLDER 1 "1/4"

IEE COPPER SOLDER $1-1 / 2 "$

TEE COPPER SOLDER 2"

CPLG COPPER SOLDER 3/4"

CPLG COPPER SOLDER I"

CPLG COPPER SOLDER $1 \cdot 1 / 4 "$

PIPE NO HUB $10 \mathrm{FT} 1-1 / 2 "$

PIPE NO HUB $10 \mathrm{FI}$
CPLG COPPER SOLDER 1/2"

PIPE NO HUB $10 \mathrm{FT} 1-1 / 4 "$
OUANIIIY MANHOURS LABOR

EQUIP

SUB.

EQUIP GIJANIIIY MANHOURS LABOR USAGE MAIERIAL CONIRACT MENI OHBP DOLLARS QIIANIIIY MANHOURS LABOR UQUIP $\begin{array}{cccc}\text { SUB. } & \text { EQUIP. } & S / C & \text { IUIAL } \\ \text { USAGE MAIERIAL CONIRACT MENI OHBP } & \text { DOLLARS }\end{array}$

\begin{tabular}{|c|c|c|}
\hline 2 EA & 7 & 273 \\
\hline $\begin{array}{r}143 \text { lf } \\
281 \text { if } \\
440 \text { if } \\
823 \text { if } \\
16 \text { if } \\
143 \text { if } \\
305 \text { if } \\
80 \text { if } \\
110 \text { if } \\
421 \text { if } \\
69 \text { lf } \\
79 \text { if } \\
82 \text { if }\end{array}$ & $\begin{array}{r}4 \\
8 \\
13 \\
25 \\
1 \\
9 \\
21 \\
6 \\
9 \\
42 \\
8 \\
9 \\
11\end{array}$ & $\begin{array}{r}156 \\
312 \\
508 \\
976 \\
39 \\
351 \\
820 \\
234 \\
351 \\
1640 \\
312 \\
351 \\
429\end{array}$ \\
\hline
\end{tabular}

188,767

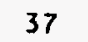

3634

0

0

367

4311

80 LF

120 if

$200 \mathrm{LF}$

80 LF

$10 \mathrm{LF}$

20 LF

$60 \mathrm{EA}$

$25 \mathrm{EA}$

40 EEE

4 EA

4 EA

$1 E A$

$6 E A$

4 EA

6 EA
5 EA

1 EA

1 EA

6 EA

3 EA

$6 \mathrm{EA}$

40 IF

40 IF

40 LF

\begin{tabular}{rrr}
23 & 23 & 0 \\
44 & 45 & 0 \\
70 & 70 & 0 \\
130 & 174 & 0 \\
5 & 4 & 0 \\
45 & 38 & 0 \\
112 & 97 & 0 \\
34 & 25 & 0 \\
46 & 35 & 0 \\
221 & 134 & 0 \\
40 & 26 & 0 \\
50 & 29 & 0 \\
60 & 30 & 0 \\
\hline 578 & & $\cdots$
\end{tabular}

157,284

$\begin{array}{rrr}78 & 8 & 77 \\ 78 & 13 & 211 \\ 156 & 21 & 469 \\ 117 & 17 & 240 \\ 0 & 2 & 38 \\ 39 & 5 & 120 \\ 78 & 13 & 35 \\ 39 & 7 & 33 \\ 78 & 13 & 127 \\ 0 & 2 & 20 \\ 0 & 2 & 31 \\ 0 & 1 & 14 \\ 0 & 2 & 6 \\ 0 & 2 & 10 \\ 39 & 4 & 43 \\ 39 & 4 & 57 \\ 0 & 1 & 16 \\ 0 & 1 & 25 \\ 0 & 1 & 3 \\ 0 & 1 & 3 \\ 0 & 3 & 15 \\ 39 & 3 & 19 \\ 117 & 15 & 64 \\ 117 & 15 & 67 \\ 117 & 14 & 55\end{array}$

84. 1315

112
374
695
400
44
177
131
83
232
24
36
17
9
13
91
106
19
29
4
4
20
63
204
207
193
207

410
662

1310

49

1050

299

440
2031

438
528

18,286

$\begin{array}{rr}9 & 112 \\ 22 & 324 \\ 49 & 695 \\ 26 & 400 \\ 4 & 44 \\ 13 & 177 \\ 5 & 131 \\ 4 & 83 \\ 14 & 232 \\ 2 & 24 \\ 3 & 36 \\ 2 & 17 \\ 1 & 9 \\ 1 & 13 \\ 5 & 91 \\ 6 & 106 \\ 2 & 19 \\ 3 & 29 \\ 0 & 4 \\ 0 & 4 \\ 2 & 20 \\ 2 & 63 \\ 8 & 204 \\ 8 & 207 \\ 7 & 193\end{array}$


ICF KAISER ENGINEERS, INC. OEPARTM JOB NO. 88107-250-00
ICF KAISER ENGINEERS INIERACTIVE ESTIMAIING 20 IPH CLEAN COAL SEMI-WORKS CONCEPTUAL DESIGN

GENERAL ESTIMAIE FOR REFERANCE
REPORT D1 - ESIIMAIE DETAIL BY FACILIIY
PAGE 18

DATE: $07 / 13 / 94 \quad 13: 21$ BY

- - WORK BREAKDOWN-..FACIL. STANDRD.WKPKG DESCRIPTION QUANIITY MANHOURS LABOR EQUIP SUB EQUIP. $\mathrm{S} / \mathrm{C}$
$\mathrm{OH} \& \mathrm{P}$ DOLLAR

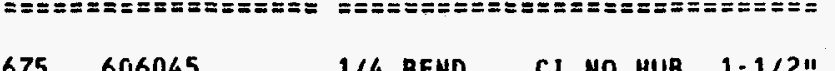

$675.606045 . \quad 1 / 4$ BEND Cl NO HUB $1-1 / 211$ 675.6060451 . $1 / 4$ BEND CI NO HUB $1-1 / 41$ 675.606046 . 1/4 BEND Cl HO HUB $2 "$ .606047. 1/8 BEND CI NO HUB $1-1 / 24$ .606048. 1/8 BEHD .606053 . SAN TEE

cI 40 HUB 211 SAN TEE CI NO HUB $1-1 / 4$ $.606054^{\circ}$ SAN TEE CI NO HUB 2" $\begin{array}{llll}.606063 & \text { P-TRAP } & \text { CI NO HUB } & 1-1 / 2 " \\ .6060631^{\circ} & \text { P-IRAP } & \text { CI NO HUB } 1-1 / 4 "\end{array}$

.606064 P-TRAP CI NO HUB

PIPE NO HUB 10 FI 3" $606634^{\circ} \quad$ PIPE NO HUB 10 FT 4"

$1 / 4$ BEND Cl NO HUB 3 "

$.606807^{\circ} \quad 1 / 4$ BEND CI NO HUB 4" .606831 . SAN TEE CI NO HUB 4" $.60682^{\circ}$ WYE CI NO HUB 4" $606867^{\circ}$ P-IRAP CI NO HU8 3" $.606868^{\circ}$. P-TRAP CI MO HUB 4" .608007: PIPE PVC D1785 PE S40 $1-1 / 411$ .608009 . PIPE PVC 01785 PE S40 $1-1 / 2$ .608011 . PIPE PVC D1785 PE S40 21" $.608027 .90 \mathrm{EL}$ PVC SOCKET S40 $1.1 / 40$ .608029 - 90 EL PVC SOCKET S40 $1.1 / 2{ }^{\prime \prime}$ .608031 - 90 EL PVC SOCKET S40 2"

$.608053^{\circ}$ TEE PVC SOCKET S40 $1.1 / 21$ $.608055^{\circ}$ IEE PVC SOCKET S40 2"

CPLG PVC SOCKET S40 $1.1 / 4 "$ CPLG PVC SOCKEI $5401.112 "$ CPLG PVC SOCKET S40 2" PIPE PVC D1785 PE S40 2-1/2" 90 EL PVC SOCKET S40 2-1/2" IEE PVC SOCKET S40 $2-1 / 21$ $\begin{array}{lll}\text { TEE PVC SOCKET S40 } & 2-1 / 2 " 1 \\ \text { CPIG PVC SOCKET S40 } 2-1 / 2 "\end{array}$ FLOOR DRAINS 3"

FLOOR DRAINS 4"

GATE VALVE, BRONZE 1-1/4" CRANE 1324, CLASS 150, SJ GATE VALVE, BROHZE $1-1 / 2 "$ CRANE 1324, CLASS 150, $\mathrm{s} J$ GATE VALVE, BRONZE 2" CRANE 1324, CLASS 150, SJ

SCREWED ENDS, 600 PSI

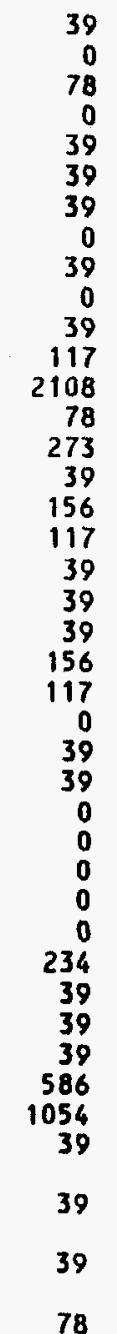

6 EA

2 EA

$1 \mathrm{EA}$

6 EA

1 EA

3 EA

4 EA

3 EA

20 LF

320 LF

8 EA

20 EA

$4 E A$

$14 E A$

$5 E A$

1 EA

$20 \mathrm{LF}$

100 IF

$60 \mathrm{LF}$

4 EA

$\begin{array}{rl}6 & E A \\ 10 & E A\end{array}$

4 EA

2 EA

1 EA

IOF

4 EA

4 EA

5 EA

9 EA

3 EA

2 EA

1 EA

4 EA MATERIAL CONIRACI

NT OHEP

$675 \quad .653021$ 
ICF KAISER ENGINEERS, INC. DEPARTMENT OF ENERGY JOB NO. B8107-250-00
ICF KAISER ENGINEERS INIERACIIVE ESTIMAIING 20 IPH CLEAN COAL SEMI-WORKS CONCEPIUAL DESIGN GENERAL ESTIMATE FOR REFERAHCE
PAGE 19

DATE: $07113 / 94 \quad 13: 21$

REPORT DI - ESIIMAIE DETAIL QY FACILIIY

DYT

\begin{tabular}{|c|c|c|c|c|c|c|c|c|c|c|c|c|}
\hline \multicolumn{3}{|c|}{$\begin{array}{l}\text { - HORK BREAKDOWN - - } \\
\text { FACIL.STANDRD. WKPKG } \\
================\end{array}$} & 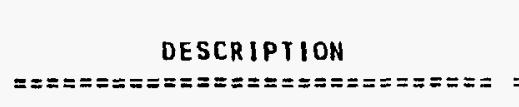 & $\begin{array}{l}\text { QUANIIIY } \\
=========\end{array}$ & $\begin{array}{l}\text { MANHOURS } \\
==== \pm===\end{array}$ & $\begin{array}{l}\text { LABOR } \\
=====\approx=\end{array}$ & $\begin{array}{l}\text { EQUIP } \\
\text { USAGE } \\
=======\end{array}$ & $\begin{array}{l}\text { MA IERIAL } \\
=======\end{array}$ & $\begin{array}{l}\text { SUB- } \\
\text { CONIRACI } \\
z======\end{array}$ & $\begin{array}{l}\text { EOUIP - } \\
\text { MENT } \\
=======\end{array}$ & $\begin{array}{l}S / C \\
\text { OH\&P } \\
=======\end{array}$ & $\begin{array}{c}\text { JUIAI } \\
\text { DOLLARS } \\
======-\end{array}$ \\
\hline 675 & .653437 & . & $\begin{array}{l}\text { BALL VAL VE, BRASS } \\
\text { JAMESBURY A11MT } \\
\text { SCREHED ENDS, } 600 \mathrm{PSI}\end{array}$ & $6 E A$ & 3 & 117 & 14 & 449 & 0 & 0 & 46 & 626 \\
\hline 675 & .653438 & - & $\begin{array}{l}\text { BALL VALVE, BRASS } \\
\text { JAMESBURY A11MT } \\
\text { SCREWED ENDS, } 600 \text { PSI }\end{array}$ & $7 \mathrm{EA}$ & 3 & 117 & 18 & 634 & 0 & 0 & 65 & 834 \\
\hline 675 & .675100 & . & $\begin{array}{l}\text { EF- } 1 \text { EXHAUST FAN } \\
50 \text { HP/TEFC/120V/1800RPM/ } \\
\text { GREENHECK MODEL BCF-108 }\end{array}$ & 1 EA & 8 & 312 & 30 & 0 & 0 & 1471 & 3 & 1810 \\
\hline 675 & .675102 & . & $\begin{array}{l}\text { EF-2 EXHAUST FAN } \\
\text { 3HP/TEFC/4BOV/1800RPM/ } \\
\text { GREENHECK MODEL SPNE-36 }\end{array}$ & $1 \mathrm{EA}$ & 8 & 312 & 30 & 0 & 0 & 742 & 3 & 1087 \\
\hline 675 & .675104 & . & $\begin{array}{l}\text { EF-3 EXHAUSI FAN } \\
5 \text { HP/TEFC/480V/1800RPM/ } \\
\text { GREENHECK MODEL SPNE }-42\end{array}$ & 1 EA & 8 & 312 & 30 & 0 & 0 & 918 & 3 & 1263 \\
\hline 675 & .675106 & . & $\begin{array}{l}\text { EF-4 EXHAUST FAN } \\
\text { IHP/TEFC/48OV/1800RPM/ } \\
\text { GREENHECK MODEL SPNE-36 }\end{array}$ & $1 E A$ & 8 & 312 & 30 & 0 & 0 & 584 & 3 & 924 \\
\hline 675 & .675108 & . & $\begin{array}{l}\text { EF-5 EXHAUSI FAN } \\
\text { 3HP/TEFC/480V/180ORPM/ } \\
\text { GREENHECK MODEL SPNE-36 }\end{array}$ & $1 \mathrm{EA}$ & 8 & 312 & 30 & 0 & 0 & 742 & 3 & 1087 \\
\hline 675 & .675110 & - & $\begin{array}{l}\text { EF-6 EXHAUSI FAN } \\
.75 \text { HP/TEFC/480V/1800RPM/ } \\
\text { GREENHECK MODEL SPNE- } 30\end{array}$ & $1 \mathrm{EA}$ & 8 & 312 & 30 & 0 & 0 & 508 & 3 & 853 \\
\hline 675 & .675120 & . & $\begin{array}{l}\text { AC- } 1 \text { AIR CONDITIONER FAN } \\
\text { H/COMPRESSOR/HEATER UNIT } \\
\text { CORRECT AIR CORP MODEL SC24 }\end{array}$ & 1 EA & 48 & 1872 & 181 & 0 & 0 & 5724 & 18 & 7795 \\
\hline 675 & .675125 & - & $\begin{array}{l}\text { AC-2 AIR CONDITIONER FAN } \\
\text { W/COMPRESSOR/HEAIER UNIT } \\
\text { ADDISON MODEL PCO44 }\end{array}$ & $1 E A$ & 48 & 1872 & 181 & 0 & 0 & 5724 & 18 & 7195 \\
\hline 675 & .675130 & . & $\begin{array}{l}\text { AC-3 AIR CONDITIONER FAN } \\
\text { W/COMPRESSOR / HEAIER UNIT } \\
\text { ADDISON MODEL PCO44 }\end{array}$ & $1 E A$ & 48 & 1872 & 181 & 0 & 0 & 5724 & 18 & 7195 \\
\hline 675 & .675135 & . & $\begin{array}{l}\text { HV-1 HEATING/VENTILATING UNIT } \\
\text { W/UHIT HEATER I6KW } \\
\text { BROD HCCLUNG MODEL CRP- } 22\end{array}$ & $1 \mathrm{EA}$ & 48 & 1872 & 181 & 0 & 0 & 11584 & 18 & 13655 \\
\hline 675 & .675140 & . & $\begin{array}{l}\text { HV-2 HEATING/VENT. UNIT FAN } \\
\text { H/UHIT HEATER } 34 \mathrm{KH} \\
\text { BROD HCCLUNG MODEL CRP- } 12\end{array}$ & $1 E A$ & 48 & 1872 & 181 & 0 & 0 & 7983 & 18 & 10054 \\
\hline 675 & .675150 & . & $\begin{array}{l}\text { UH- } 1 \text { UNIT HEATER A-G } \\
\text { 1OKH } \\
\text { Q-MARK MODEL MUH-10-4 }\end{array}$ & $7 \mathrm{EA}$ & 112 & 4368 & 422 & 0 & 0 & 6307 & 42 & 11139 \\
\hline 675 & .675152 & $\cdot$ & $\begin{array}{l}\text { UH-2 UNIT HEATER A-U } \\
15 \mathrm{KW}\end{array}$ & $21 E A$ & 336 & 13105 & 1265 & 0 & 0 & 21370 & 127 & 35861 \\
\hline
\end{tabular}


ICF KAISER ENGINEERS, INC. DEPARTMENT OF ENERGY JOB NO. 88107-250-00
ICF KAISER EMGINEERS INTERACTIVE ESTIMAIING 20 YPH CLEAN COAL SEMI-WORKS CONCEPTUAL DESIGN GENERAL ESTIMATE FOR REFERANCE
PAGE 20

DAIE: $07 / 13 / 94 \quad 13: 21$
BY

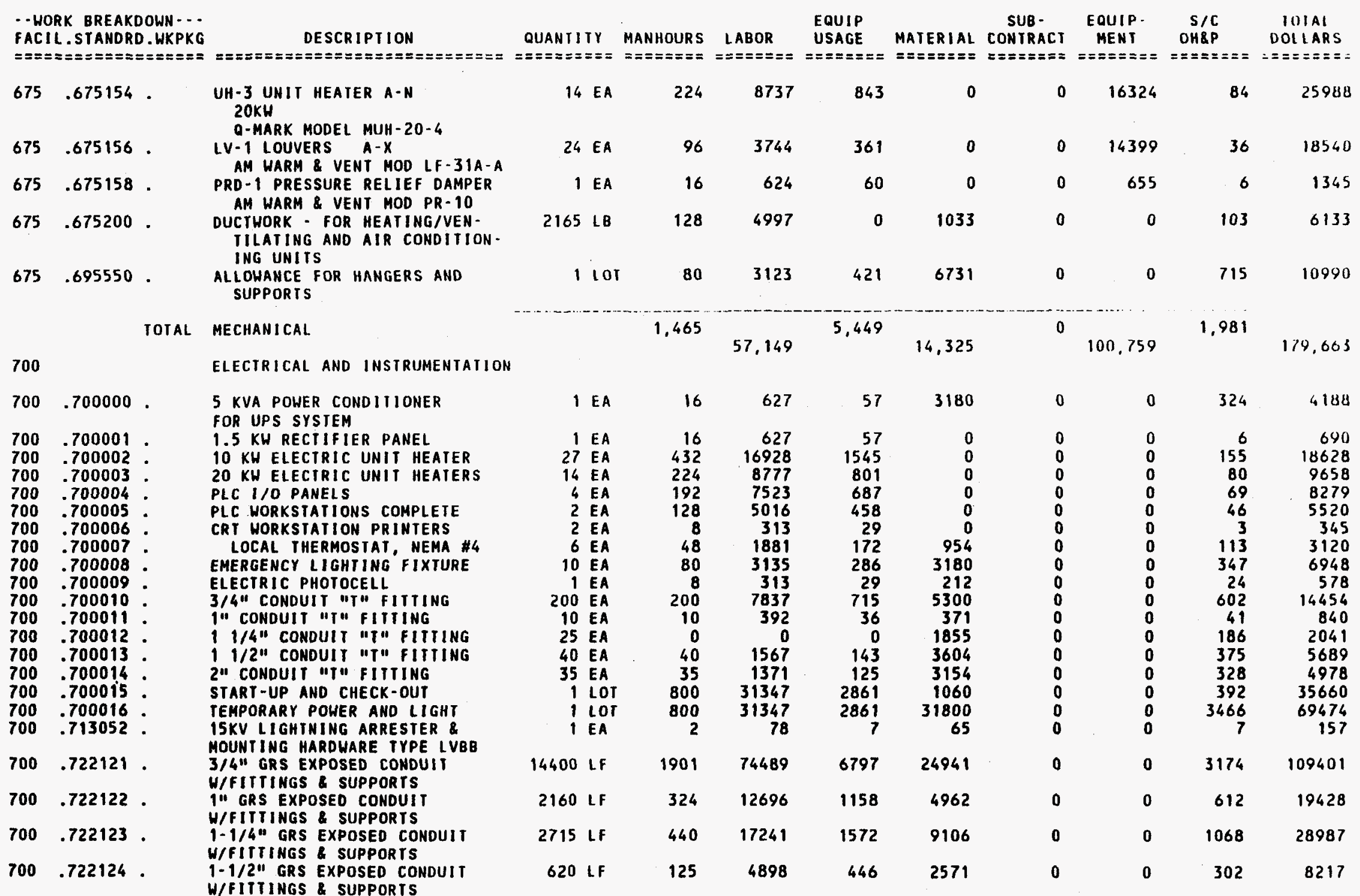


ICF KAISER ENGINEERS, INC. OEPARTMENT OF ENERGY JOB NO. $88107-250-00$
ICF KAISER ENGINEERS INTERACIIVE ESTIMATING

20 TPH CLEAN COAL SEMI-WORKS CONCEPTUAL DESIGN GENERAL ESTIMATE FOR REFERANCE

REPORT DI . ESTIMATE DETAIL BY FACILITY
PAGE 21

DAIE: $07 / 13 / 94 \quad 13: 21$

\begin{tabular}{|c|c|c|c|c|c|c|c|c|c|c|c|c|c|}
\hline \multicolumn{3}{|c|}{$\begin{array}{l}\text { - HORK BREAKDOWH... } \\
\text { FACIL. SIANDRD. WKPKG } \\
============\pi==\end{array}$} & 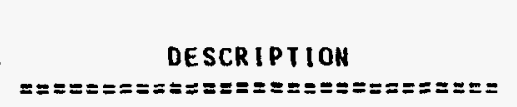 & $\begin{array}{l}\text { QUANIII } \\
=======\end{array}$ & & $\begin{array}{l}\text { MANHOURS } \\
=======\end{array}$ & $\begin{array}{l}\text { LABOR } \\
=\approx=\approx=\approx=\approx\end{array}$ & $\begin{array}{l}\text { EQUIP } \\
\text { USAGE } \\
=====\pi=\end{array}$ & $\begin{array}{l}\text { MA TER I AL } \\
=======\end{array}$ & $\begin{array}{l}\text { SUB- } \\
\text { CONTRACT } \\
======\approx\end{array}$ & $\begin{array}{l}\text { EQUIP. } \\
\text { MENI } \\
=======\end{array}$ & $\begin{array}{c}S / C \\
\text { OH\&P } \\
=======\end{array}$ & $\begin{array}{c}\text { IOIAL } \\
\text { DOLLARS } \\
==:=====\end{array}$ \\
\hline 700 & .722125 & - & $\begin{array}{l}\text { 2" GRS EXPOSED CONDUIT } \\
\text { W/FIITINGS \& SUPPORTS }\end{array}$ & 1950 & LF & 478 & 18730 & 1708 & 10796 & 0 & 0 & 1250 & 32484 \\
\hline 700 & .722126 & - & $\begin{array}{l}2-1 / 2 " \text { GRS EXPOSED CONDUIT } \\
\text { W/FITIINGS \& SUPPORTS }\end{array}$ & 500 & If & 162 & 6348 & 580 & 4812 & 0 & 0 & 539 & 12279 \\
\hline 700 & .722127 & - & $\begin{array}{l}\text { 3" GRS EXPOSEO CONDUIT } \\
\text { W/FITTINGS \& SUPPORTS }\end{array}$ & 900 & LF & 363 & 14224 & 1297 & 10953 & 0 & 0 & 1225 & 27699 \\
\hline 700 & .731121 & - & $\begin{array}{l}3 / C \text { \#4 EPR 15KV SHIELDED } \\
\text { COPPER CABLE }\end{array}$ & 40 & LF & 3 & 118 & 9 & 354 & 0 & 0 & 36 & 517 \\
\hline 700 & .731124 & . & $\begin{array}{l}\text { 3/C \#1/O EPR ISKV SHIELDED } \\
\text { COPPER CABLE }\end{array}$ & 70 & L.f & 6 & 235 & 21 & 890 & 0 & 0 & 91 & 1237 \\
\hline 700 & .731125 & - & $\begin{array}{l}3 / C \# 2 / 0 \text { EPR } 15 \mathrm{KV} \text { SHIELDED } \\
\text { COPPER CABLE }\end{array}$ & 100 & If & 9 & 353 & 32 & 1431 & 0 & 0 & 146 & 1962 \\
\hline 700 & .732126 & . & $\begin{array}{l}3 / C \# 2 / 0 \text { EPR } 5 K V \\
\text { SHIELDED COPPER CABLE }\end{array}$ & 250 & LF & 20 & 784 & 72 & 2319 & 0 & 0 & 239 & 3414 \\
\hline 700 & .733042 & . & $\begin{array}{l}\text { \#10 IHHN, } 1 / C, \mathrm{CU}, \\
\text { 6OOV HIRE }\end{array}$ & 9500 & If & 76 & 2978 & 276 & 1208 & 0 & 0 & 148 & 4610 \\
\hline $\begin{array}{l}700 \\
700\end{array}$ & .733201 & $\dot{.}$ & $\begin{array}{l}3 / C \# 12 \text { 600V PWR CBL TYPE IC } \\
3 / C \# 10 \text { 600V PWR CBL TYPE IC }\end{array}$ & $\begin{array}{l}8000 \\
2200\end{array}$ & $\operatorname{LF}$ & $\begin{array}{l}80 \\
31 \\
35\end{array}$ & $\begin{array}{r}3135 \\
1215 \\
080\end{array}$ & $\begin{array}{r}288 \\
110 \\
89\end{array}$ & $\begin{array}{l}4927 \\
1912 \\
1408\end{array}$ & $\begin{array}{l}0 \\
0 \\
0\end{array}$ & $\begin{array}{l}0 \\
0 \\
0\end{array}$ & $\begin{array}{l}522 \\
202 \\
150\end{array}$ & $\begin{array}{l}8872 \\
3439 \\
2627\end{array}$ \\
\hline $\begin{array}{l}700 \\
700 \\
700\end{array}$ & $\begin{array}{l}.733203 \\
.733204 \\
.733205\end{array}$ & $\dot{.}$ & 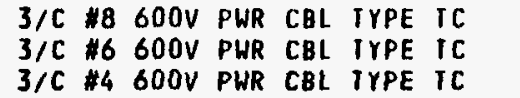 & $\begin{array}{r}1000 \\
700 \\
200\end{array}$ & $\begin{array}{l}\text { IF } \\
\text { IF } \\
\text { LF }\end{array}$ & $\begin{array}{r}25 \\
25 \\
9\end{array}$ & $\begin{array}{l}980 \\
980 \\
353\end{array}$ & $\begin{array}{l}89 \\
90 \\
33\end{array}$ & $\begin{array}{r}1408 \\
1288 \\
514\end{array}$ & $\begin{array}{l}0 \\
0 \\
0\end{array}$ & $\begin{array}{l}0 \\
0 \\
0\end{array}$ & $\begin{array}{r}150 \\
138 \\
55\end{array}$ & $\begin{array}{r}2627 \\
2496 \\
955\end{array}$ \\
\hline $\begin{array}{l}700 \\
700 \\
700 \\
700\end{array}$ & $\begin{array}{l}.733206 \\
.733208 \\
.733209 \\
.733213\end{array}$ & $\dot{:}$ & $\begin{array}{l}3 / C \# 2600 \mathrm{~V} \text { PWR CBL IYPE IC } \\
3 / \mathrm{C} \# 1 / 0600 \mathrm{P} \text { PUR CBL TYPE IC } \\
3 / C \# 2 / 0600 \mathrm{PHR} \text { CBL IYPE IC } \\
3 / \mathrm{C} 350 \mathrm{MCM} 600 \mathrm{~V} \text { PWR CBL }\end{array}$ & $\begin{array}{r}130 \\
670 \\
230 \\
1200\end{array}$ & $\begin{array}{l}\text { If } \\
\text { LF } \\
\text { LF }\end{array}$ & $\begin{array}{r}7 \\
41 \\
16 \\
121\end{array}$ & $\begin{array}{r}274 \\
1607 \\
627 \\
4741\end{array}$ & $\begin{array}{r}23 \\
146 \\
57 \\
433\end{array}$ & $\begin{array}{r}509 \\
3509 \\
1437 \\
17374\end{array}$ & $\begin{array}{l}0 \\
0 \\
0 \\
0\end{array}$ & $\begin{array}{l}0 \\
0 \\
0 \\
0\end{array}$ & $\begin{array}{r}53 \\
366 \\
149\end{array}$ & $\begin{array}{r}859 \\
5628 \\
2270 \\
26320\end{array}$ \\
\hline 700 & .733213 & . & $\begin{array}{l}3 / C 350 \text { MCM } 600 \mathrm{~V} \text { PWR CBL } \\
\text { TYPE IC }\end{array}$ & 1200 & LF & 121 & 4741 & & 17374 & 0 & 0 & 1781 & \\
\hline 700 & .733401 & . & $\begin{array}{l}2 / C \# 14 \text { 60OV CONTROL CABLE } \\
\text { IYPE IC }\end{array}$ & 5500 & LF & 50 & 1959 & 176 & 2419 & 0 & 0 & 260 & 4814 \\
\hline 700 & .733402 & . & $\begin{array}{l}3 / C \# 14 \text { 60OV CONTROL CABLE } \\
\text { TYPE TC }\end{array}$ & 1200 & LF & 12 & 470 & 43 & 613 & 0 & 0 & 66 & 1192 \\
\hline 700 & .733404 & . & $\begin{array}{l}\text { 5/C \#14 600V CONTROL CABLE } \\
\text { TYPE IC }\end{array}$ & 2200 & I. F & 26 & 1019 & 95 & 1782 & 0 & 0 & 188 & 3084 \\
\hline 700 & .733407 & . & $\begin{array}{l}\text { B/C \#14 6OOV CONTROL CABLE } \\
\text { TYPE IC }\end{array}$ & 600 & $L F$ & 9 & 353 & 32 & 585 & 0 & 0 & 62 & 1032 \\
\hline $\begin{array}{l}700 \\
700\end{array}$ & $\begin{array}{l}.734121 \\
.734512\end{array}$ & $\dot{.}$ & $\begin{array}{l}\text { IPR \#16 SHIELDED CABLE } \\
\text { COAXIAL CABLE, RG A/U } 59 \\
75 \text { OHMS, FIRE RATED }\end{array}$ & $\begin{array}{r}8500 \\
200\end{array}$ & $\begin{array}{l}\text { IF } \\
\text { LF }\end{array}$ & $\begin{array}{r}85 \\
3\end{array}$ & $\begin{array}{r}3331 \\
118\end{array}$ & $\begin{array}{r}306 \\
11\end{array}$ & $\begin{array}{r}1352 \\
350\end{array}$ & $\begin{array}{l}\mathbf{0} \\
\mathbf{0}\end{array}$ & $\begin{array}{l}0 \\
0\end{array}$ & $\begin{array}{r}166 \\
36\end{array}$ & $\begin{array}{r}5155 \\
515\end{array}$ \\
\hline 700 & .741001 & . & $\begin{array}{l}1 / C \text { W6 TO } 1 / 0 \text { 15KV TERM } \\
\text { INCL HI-POITING }\end{array}$ & 18 & EA & 72 & 2821 & 258 & 1431 & 0 & 0 & 169 & 4679 \\
\hline 700 & .742006 & - & $\begin{array}{l}\text { I/C \#2/0 TO } 4 / 0 \text { 5KV TERM. } \\
\text { INCL HI-POTIING }\end{array}$ & 12 & EA & 48 & 1881 & 172 & 890 & 0 & 0 & 106 & 3049 \\
\hline 700 & .743001 & . & $\begin{array}{l}\text { I/C \#16 TO } 10 \text { SOLDERLESS } \\
\text { TERMINAL LUGS, 600V }\end{array}$ & 2893 & $E A$ & 463 & 18142 & 1655 & 1135 & 0 & 0 & 279 & 21211 \\
\hline 700 & .743002 & . & $\begin{array}{l}\text { 1/C \#8 TO \#4 SOLDERLESS } \\
\text { TERMINAL LUGS,600V }\end{array}$ & 78 & $E A$ & 21 & 823 & 75 & 103 & 0 & 0 & 18 & 1019 \\
\hline
\end{tabular}


ICF KAISER ENGINEERS, INC. DEPARTMENT OF ENERGY JOB NO. B8107-250-00
ICF KAISER ENGINEERS INIERACTIVE ESTIMATING 20 IPH CLEAN COAL SEMI-HORKS CONCEPTUAL DESIGN GENERAL ESTIMATE FOR REFERANCE
PAGE 22

DAIE: $07 / 13 / 94 \quad 13: 27$ BY

REPORT D1 - ESIIMAIE DETAIL BY FACILIIY

\begin{tabular}{|c|c|c|c|c|c|c|c|c|c|c|c|c|c|}
\hline $\begin{array}{l}- \text { WOR } \\
\text { FAC } 11 \\
=====\end{array}$ & $\begin{array}{l}\text { RK BREAKD } \\
\text {.STANDRD } \\
======\approx==\end{array}$ & WWH -... & 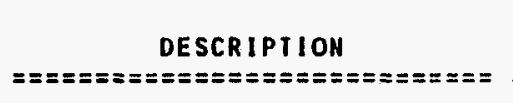 & $\begin{array}{l}\text { QUANIIT } \\
==\approx=====\end{array}$ & & $\begin{array}{l}\text { MANHOURS } \\
========\end{array}$ & $\begin{aligned} & \text { LABOR } \\
&====:===\end{aligned}$ & $\begin{array}{l}\text { EQUIP } \\
\text { USAGE } \\
=======\end{array}$ & $\begin{array}{l}\text { MAIER IAL } \\
========\end{array}$ & $\begin{array}{l}\text { SUB. } \\
\text { CONTRACI } \\
=======\end{array}$ & $\begin{array}{l}\text { EQUIP. } \\
\text { MENI } \\
========\end{array}$ & $\begin{array}{c}\text { S/C } \\
\text { OH\&P } \\
========\end{array}$ & $\begin{array}{c}\text { IOIAL } \\
\text { DOLIARS } \\
========\end{array}$ \\
\hline 700 & .743003 & . & $\begin{array}{l}\text { 1/C \#2 TO \#1 SOLDERLESS } \\
\text { TERMINAL LUGS,600V }\end{array}$ & & EA & 2 & 78 & 8 & 18 & 0 & 0 & 3 & 107 \\
\hline 700 & .743004 & . & $\begin{array}{l}1 / C \# 1 / 0 \text { IO } \# 2 / 0 \text { SOLDERLESS } \\
\text { TERMINAL LUGS, } 600 \mathrm{~V}\end{array}$ & 48 & EA & 24 & 940 & 86 & 285 & 0 & 0 & 37 & 1348 \\
\hline 700 & .743008 & . & $\begin{array}{l}\text { I/C } 350 \text { MCM SOLDERLESS } \\
\text { TERMINAL LUGS, } 600 \mathrm{~V}\end{array}$ & 114 & EA & 130 & 5094 & 465 & 1601 & 0 & 0 & 207 & 7367 \\
\hline 700 & .743009 & - & $\begin{array}{l}\text { 1/C } 500 \text { MCM SOLDERLESS } \\
\text { TERMINAL LUGS, } 600 \mathrm{~V}\end{array}$ & 20 & EA & 27 & 1058 & 95 & 281 & 0 & 0 & 38 & 1472 \\
\hline 700 & .751021 & - & $\begin{array}{l}\text { FEEDER BREAKER DRAWOUT } \\
\text { TYPE, } 1200 \mathrm{~A}, 500 \text { MVA, } 13.8 \mathrm{KV}\end{array}$ & 3 & EA & 180 & 7053 & 644 & 0 & 0 & 79500 & 64 & 87261 \\
\hline 700 & .751209 & . & $\begin{array}{l}\text { XFORMER, PAD MTD, OIL FILLED } \\
13.8 \mathrm{KV} / 480 / 277 \mathrm{~V}, 3 \mathrm{PH}, 1000 \mathrm{KVA}\end{array}$ & 1 & EA & 80 & 3135 & 286 & 0 & 0 & 15688 & 29 & 19138 \\
\hline 700 & .751228 & . & $\begin{array}{l}\text { XFORMER, PAD MTD, SILICON FLD } \\
13.8 \mathrm{KV} / 480 / 277 \mathrm{~V}, 2500 \mathrm{KVA}\end{array}$ & 1 & EA & 140 & 5486 & 501 & 0 & 0 & 48654 & 50 & 54691 \\
\hline 700 & .752050 & . & $\begin{array}{l}\text { STARTER FVNR } 4.16 \mathrm{KV} \text { TO } \\
1250 \mathrm{HP} \text { CLASS E-2 }\end{array}$ & 1 & $E A$ & 40 & 1567 & 143 & 0 & 0 & 13886 & 14 & 156111 \\
\hline 700 & .753006 & . & $\begin{array}{l}\text { 480V DRAWOUT AIR CIRCUIT BRKR } \\
800 A \text { (ELECTRIC) }\end{array}$ & 8 & $E A$ & 192 & 7523 & 687 & 0 & 64 & 61056 & 69 & 69394 \\
\hline 700 & .753010 & . & $\begin{array}{l}\text { 4BOV DRAWOUT AIR CIRCUII BRKR } \\
4000 A \text { (ELECIRIC) }\end{array}$ & 1 & EA & 60 & 2351 & 215 & 0 & 8 & 45707 & 22 & 48305 \\
\hline 700 & .753150 & . & $\begin{array}{l}\text { COMBINATION CKT BRKR STARTER } \\
\text { MCC MOUNTED, NEMA } 1 \text { CLIASS } 2 \\
\text { TYPE B, } 480 \mathrm{~V} \text {, FVNR SIZE } 1\end{array}$ & 45 & EA & 135 & 5290 & 483 & 0 & 0 & 45792 & 48 & 51613 \\
\hline 700 & .753151 & . & $\begin{array}{l}\text { COMBINATION CKT BRKR STARIER } \\
\text { MCC MOUNTED, NEMA } 1 \text {, CLASS } 2 \\
\text { TYPE B, 480V, FVNR SIZE } 2\end{array}$ & 7 & EA & 42 & 1646 & 150 & 0 & 0 & 8533 & 15 & 10344 \\
\hline 700 & .753152 & - & $\begin{array}{l}\text { COMBINATION CKI BRKR STARTER } \\
\text { MCC MOUNIED, NEMA } 1, \text { CLASS } 2 \\
\text { TYPE B, } 480 \mathrm{~V} \text {, FVNR SIZE } 3\end{array}$ & 5 & EA & 40 & 1567 & 143 & 0 & 0 & 9275 & 14 & 10999 \\
\hline 700 & .753153 & - & $\begin{array}{l}\text { COMBINÁTION CKT BRKR STARTER } \\
\text { HCC MOUNTEO, NEMA } 1 \text {, CLASS } 2 \\
\text { TYPE B, } 480 \mathrm{~V} \text {, FVHR SILE } 4\end{array}$ & 9 & EA & 108 & 4232 & 386 & 0 & 0 & 30910 & 39 & 35567 \\
\hline 700 & .753154 & - & $\begin{array}{l}\text { COMBINATION CKT BRKR STARTER } \\
\text { MCC MOUNTED, NEMA } 1, \text { CLASS } 2 \\
\text { TYPE B, } 480 \mathrm{~V}, \text { FVHR SIZE } 5\end{array}$ & 2 & EA & 36 & 1411 & 129 & 0 & 0 & 14034 & 13 & 15587 \\
\hline $\begin{array}{l}700 \\
700 \\
700 \\
700 \\
700\end{array}$ & $\begin{array}{l}.753180 \\
.753182 \\
.753190 \\
.753191 \\
.753231\end{array}$ & : & $\begin{array}{l}\text { CKT BRKR MCC MTD, } 480 \mathrm{~V}-15-100 \mathrm{~A} \\
\text { CKI BRKR MCC MID, } 480 \mathrm{~V}, 400 \mathrm{~A} \\
\text { MCC, MAIN BRKR, } 480 \mathrm{~V}, 600 \mathrm{~A} \\
\text { MCC, MAIN BRKR, } 480 \mathrm{~V}, 800 A \\
\text { TRAMSFORMER, DRY INDOOR } \\
5 \text { KVA, } 480 \mathrm{~V}-120 / 208 \mathrm{O}, 3 \mathrm{PH}\end{array}$ & $\begin{array}{r}75 \\
2 \\
2 \\
4 \\
1\end{array}$ & $\begin{array}{l}E A \\
E A \\
E A \\
E A \\
E A\end{array}$ & $\begin{array}{l}75 \\
10 \\
32 \\
72 \\
11\end{array}$ & $\begin{array}{r}2939 \\
392 \\
1254 \\
2821 \\
431\end{array}$ & $\begin{array}{r}268 \\
36 \\
114 \\
258 \\
39\end{array}$ & $\begin{array}{l}0 \\
0 \\
0 \\
0 \\
0\end{array}$ & $\begin{array}{l}0 \\
0 \\
0 \\
0 \\
0\end{array}$ & $\begin{array}{r}29018 \\
3328 \\
4632 \\
13059 \\
413\end{array}$ & $\begin{array}{r}27 \\
4 \\
11 \\
26 \\
4\end{array}$ & $\begin{array}{r}32252 \\
3760 \\
6011 \\
16164 \\
887\end{array}$ \\
\hline 00 & .753234 & - & $\begin{array}{l}\text { TRANSFORHER, ORY INDOOR } \\
30 \mathrm{KVA}, 480 \mathrm{~V}-120 / 20 \mathrm{BV}, 3 \mathrm{PH}\end{array}$ & 1 & EA & 20 & 784 & 72 & 0 & 0 & 1060 & 7 & 1923 \\
\hline 700 & .753301 & . & $\begin{array}{l}\text { UPS } 5 \text { KVA } 480 V \text { INCLUDING } \\
30 \text { MIN BATTERY BACKUP }\end{array}$ & 1 & EA & 48 & 1881 & 172 & 0 & 0 & 21200 & 17 & 23270 \\
\hline
\end{tabular}


ICF KAISER ENGINEERS, INC. DEPARTMENT OF ENERGY JOB NO. 88107-250-00
ICF KAISER ENGINEERS INIERACIIVE ESTIMAIING 20 IPH CLEAN COAL SEMI-WORKS CONCEPTUAL DESIGN GENERAL ESTIMATE FOR REFERANCE

REPORT D1 - ESIIMAIE DEIAIL BY FACILITY
PAGE 23

DATE : $07 / 13 / 94 \quad 13: 27$

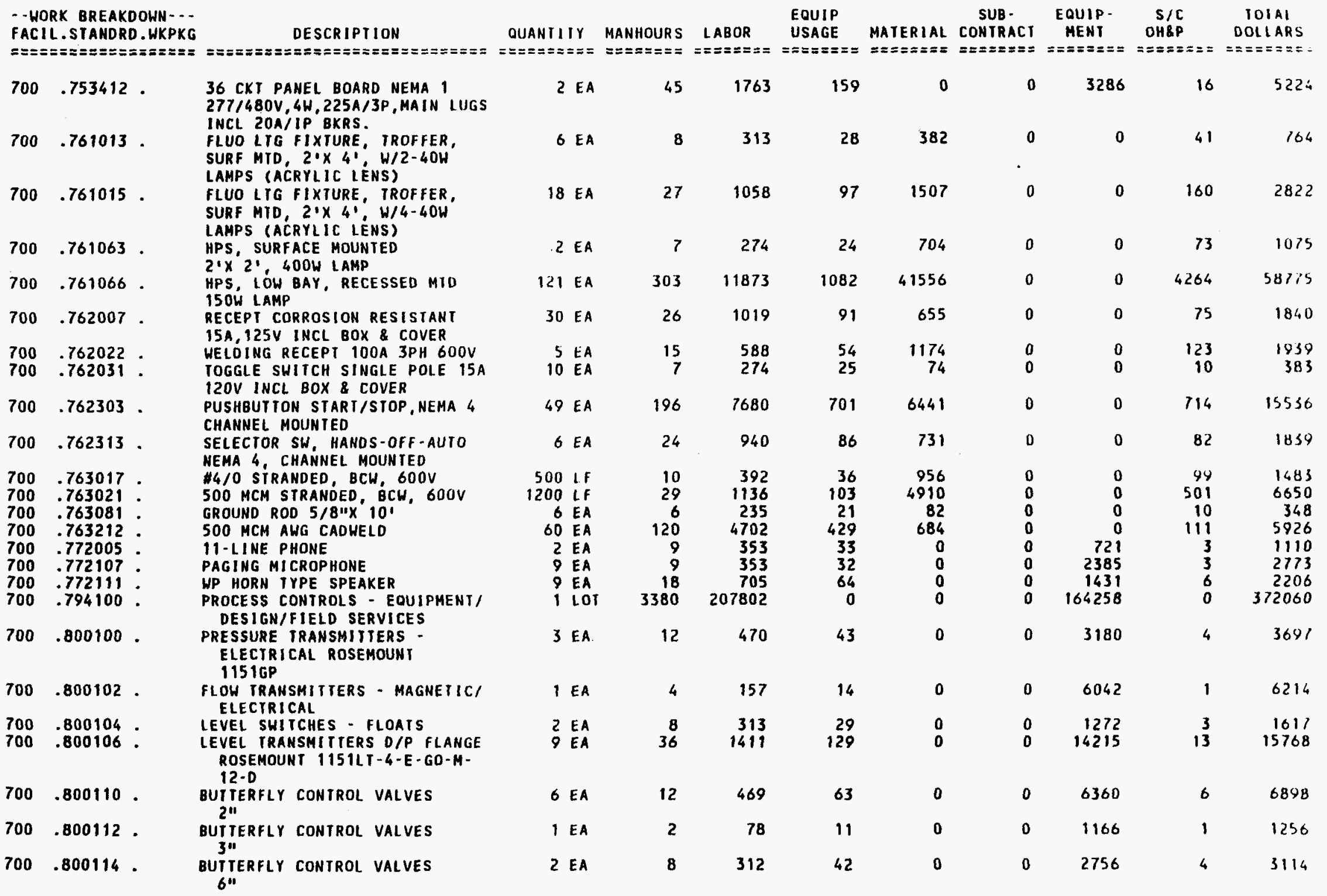


ICF KAISER ENGINEERS, INC. DEPARTMENT OF ENERGY JOB NO. 88107-250-00
ICF KAISER ENGINEERS INIERACTIVE ESTIMAIING 20 IPH CLEAN COAL SEMI-WORKS CONCEPTUAL DESIGN GENERAL ESTIMATE FOR REFERANCE
PAGE 24

DATE: $07 / 13 / 94 \quad 13: 27$

\begin{tabular}{|c|c|c|c|c|c|c|c|c|c|c|c|c|}
\hline \multicolumn{3}{|c|}{$\begin{array}{l}- \text { - HORK BREAKDOWN }-. . \\
\text { FACIL. STANORD. WKPKG } \\
=================\end{array}$} & 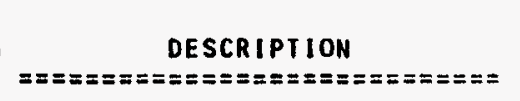 & \multirow{2}{*}{ 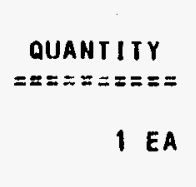 } & \multirow{2}{*}{$\begin{array}{r}\text { MANHOURS } \\
======= \\
8\end{array}$} & \multirow{2}{*}{ 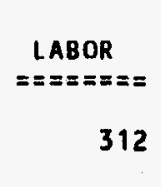 } & \multirow{2}{*}{ 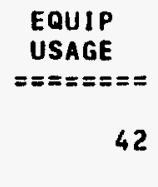 } & \multirow{2}{*}{$\begin{array}{r}\operatorname{MATERIAL} \\
======= \\
0\end{array}$} & \multirow{2}{*}{ 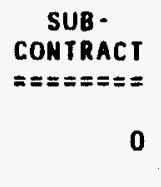 } & \multirow{2}{*}{ 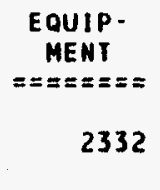 } & \multirow{2}{*}{ 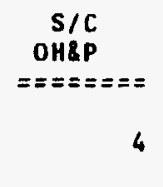 } & \multirow{2}{*}{ 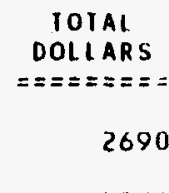 } \\
\hline 700 & .800116 & - & $\begin{array}{l}\text { BUTYERFLY CONTROL VALVES } \\
14^{n}\end{array}$ & & & & & & & & & \\
\hline 700 & .800120 & - & $\begin{array}{l}\text { ANALYZER - PH } \\
\text { ROSEMOUNT } 2000 \quad 1054 \mathrm{PH}\end{array}$ & 1 EA & 8 & 313 & 29 & 0 & 0 & 2226 & 3 & 2571 \\
\hline \multirow[t]{2}{*}{$\begin{array}{l}700 \\
700 \\
700\end{array}$} & $\begin{array}{l}.800122 \\
.800124 \\
.800126\end{array}$ & $\therefore$ & $\begin{array}{l}\text { ANALYZER - DENSITY-NUCLEAR } \\
\text { AHALYZER - TURBIDITY } \\
\text { POWER POSITIONER - PNEUMATIC }\end{array}$ & $\begin{array}{l}3 \text { EA } \\
2 \text { EA } \\
2 \text { EA }\end{array}$ & $\begin{array}{l}24 \\
16 \\
32\end{array}$ & $\begin{array}{r}940 \\
627 \\
1254\end{array}$ & $\begin{array}{r}86 \\
57 \\
114\end{array}$ & $\begin{array}{l}0 \\
0 \\
0\end{array}$ & $\begin{array}{l}0 \\
0 \\
0\end{array}$ & $\begin{array}{r}18603 \\
7844 \\
3604\end{array}$ & $\begin{array}{r}9 \\
6 \\
11\end{array}$ & $\begin{array}{r}19638 \\
8534 \\
4983\end{array}$ \\
\hline & & TOTAL & $\begin{array}{l}\text { ELECTRICAL AND INSIRUMENTATION } \\
\text { INDIRECIS AND DISTRIBUTABLES }\end{array}$ & & 14,003 & 624,051 & 38,033 & 234.657 & 72 & 687,426 & 27.274 & $1,611,513$ \\
\hline $\begin{array}{l}900 \\
900 \\
900 \\
900\end{array}$ & $\begin{array}{l}.901005 \\
.901010 \\
.901015 \\
.901035\end{array}$ & : & $\begin{array}{l}\text { SURVEY SERVICES } \\
\text { IEMPORARY FIELD FAB SHOP } \\
\text { TEMPORARY POWER } \\
\text { FIELD CONSIRUCIION TRAIIERS } \\
\text { ( } 2 \text { EA) }\end{array}$ & $\begin{array}{rl}1 & \text { LOT } \\
1 & \text { LOT } \\
1 & \text { LOT } \\
12 & \mathrm{MO}\end{array}$ & $\begin{array}{r}0 \\
240 \\
240 \\
0\end{array}$ & $\begin{array}{r}0 \\
8819 \\
9404 \\
0\end{array}$ & $\begin{array}{r}0 \\
1116 \\
858 \\
0\end{array}$ & $\begin{array}{r}0 \\
5300 \\
10600 \\
6360\end{array}$ & $\begin{array}{r}10000 \\
0 \\
0 \\
0\end{array}$ & $\begin{array}{l}0 \\
0 \\
0 \\
0\end{array}$ & $\begin{array}{r}0 \\
642 \\
1146 \\
636\end{array}$ & $\begin{array}{r}10000 \\
15877 \\
22008 \\
6996\end{array}$ \\
\hline $\begin{array}{l}900 \\
900 \\
900 \\
900\end{array}$ & $\begin{array}{l}.901040 \\
.901045 \\
.901050 \\
.901055\end{array}$ & $\dot{:}$ & $\begin{array}{l}\text { TOOL TRAILERS ( } 2 \text { EA) } \\
\text { PORT A JOHNS ( } 3 \text { EA) } \\
\text { POTABLE DRINKING WATER } \\
\text { ALLOWANCE FOR BARRICADES AND } \\
\text { LIGHTS }\end{array}$ & $\begin{aligned} 12 & \text { MO } \\
12 & \text { MO } \\
1 & \text { LOT } \\
1 & \text { LOT }\end{aligned}$ & $\begin{array}{r}0 \\
0 \\
0 \\
160\end{array}$ & $\begin{array}{r}0 \\
0 \\
0 \\
5879\end{array}$ & $\begin{array}{r}0 \\
0 \\
0 \\
744\end{array}$ & $\begin{array}{l}5088 \\
2862 \\
1060 \\
1590\end{array}$ & $\begin{array}{l}0 \\
0 \\
0 \\
0\end{array}$ & $\begin{array}{l}0 \\
0 \\
0 \\
0\end{array}$ & $\begin{array}{l}509 \\
286 \\
106 \\
233\end{array}$ & $\begin{array}{l}5597 \\
3148 \\
1166 \\
8446\end{array}$ \\
\hline 900 & .901060 & . & $\begin{array}{l}\text { PICK UP TRUCKS (2 EA) } \\
\text { RENTAL }\end{array}$ & $12 \mathrm{MO}$ & 0 & 0 & 0 & 7632 & 0 & 0 & 763 & 8395 \\
\hline 900 & .901065 & • & $\begin{array}{l}\text { ALLOWANCE FOR FUEL, OIL AND } \\
\text { GREASE FOR PICK UP TRUCKS }\end{array}$ & 1 LOT & 0 & 0 & 0 & 4240 & 0 & 0 & 424 & 4664 \\
\hline \multirow[t]{2}{*}{900} & .901070 & - & FIELD HAREHOUSE & $1 \mathrm{LOT}$ & 320 & 11758 & 1487 & 12720 & 0 & 0 & 1421 & 27386 \\
\hline & & TOTAL & $\begin{array}{l}\text { INDIRECTS ANO DISTRIBUTABLES } \\
\text { ENGINEERING }\end{array}$ & & 960 & 35.860 & 4,205 & 57,452 & 10,000 & 0 & 6,166 & 113,683 \\
\hline \multirow[t]{2}{*}{901} & .901015 & - & $\begin{array}{l}\text { DESIGH EHGINEERING SERVICES } \\
\text { H/BURDEN AND EXPENSES } \\
\text { FOR SITE SPECIFIC DESIGN }\end{array}$ & 1 LOT & 0 & 0 & 0 & 0 & 600000 & 0 & 0 & 600000 \\
\hline & & TOIAL & $\begin{array}{l}\text { ENGINEERING } \\
\text { PROJECT/CONSIRUCTION MANAGEMENT }\end{array}$ & & 0 & 0 & 0 & 0 & 600,000 & 0 & 0 & 600,000 \\
\hline 902 & .902005 & - & $\begin{array}{l}\text { CONSTRUCTION MANAGEMENT } \\
\text { PERSONNEL H/BURDEN AND } \\
\text { EXPENSES } \\
\text { PROJECT MANAGEMENT SERVICES }\end{array}$ & 1 LOT & $\mathbf{0}$ & 0 & 0 & 0 & 250000 & 0 & 0 & 250000 \\
\hline & $.90<0<0$ & - & $\begin{array}{l}\text { PROJECT RANAGEMENT SERVICES } \\
\text { W/BURDEN AND EXPEHSES }\end{array}$ & 1 LOT & 0 & 0 & 0 & 0 & 350000 & 0 & 0 & 350000 \\
\hline
\end{tabular}


ICF KAISER ENGINEERS, INC.

DEPARTMENT OF ENERGY

JOB NO. $88107-250-00$

- WORK BREAKDOWH -..

FACIL. STANDRO. WKPKG

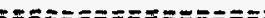

TOTAL PROJECT/CONSTRUCTION MANAGEMEN

DESCRIPTIOH

ICF KAISER ENGINEERS INTERACTIVE ESTIMAIING

20 IPH CLEAN COAL SEMI-WORKS CONCEPTUAL DESIGH GENERAL ESTIMATE FOR REFERANCE

REPORT DI - ESIIMATE DETAIL BY FACILITY
PAGE 25

DATE : $07 / 13 / 94 \quad 13: 2$

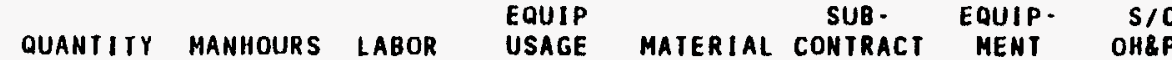

S/C IOIAL

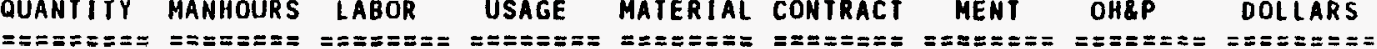

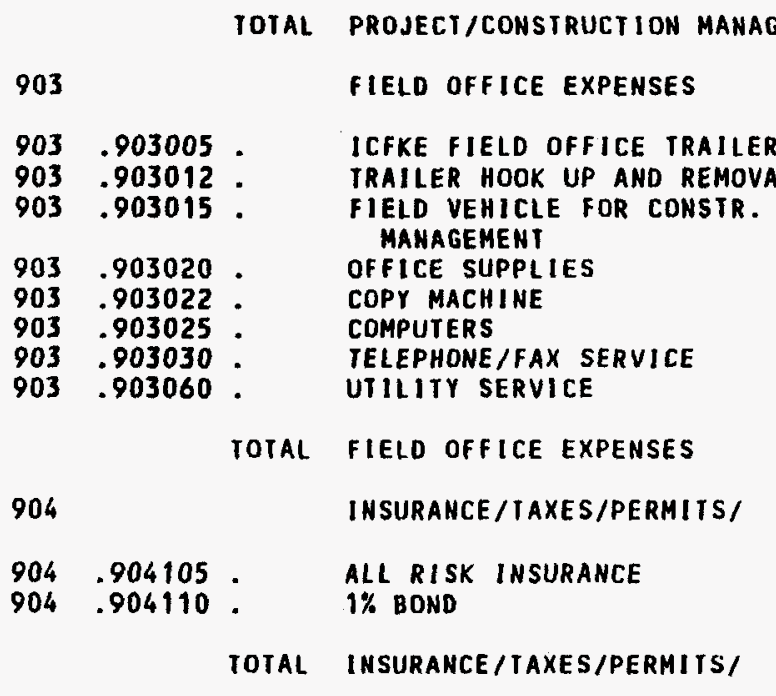

REPORT TOTAL
0

0

$\mathbf{0}$
600,000

0
0

600,000

\begin{tabular}{rrrrrrrrrr}
12 & MO & 0 & 0 & 0 & 6360 & 0 & 0 & 0 & 6360 \\
1 & EA & 80 & 2940 & 372 & 0 & 1000 & 0 & 0 & 4312 \\
12 MO & 0 & 0 & 0 & 5088 & 0 & 0 & 0 & 5088 \\
12 & MO & 0 & 0 & 0 & 2544 & 0 & 0 & 0 & 2544 \\
12 & MO & 0 & 0 & 0 & 1908 & 0 & 0 & 0 & 1908 \\
2 & EA & 0 & 0 & 0 & 10600 & 0 & 0 & 0 & 10600 \\
12 & MO & 0 & 0 & 0 & 3816 & 0 & 0 & 0 & 3816 \\
12 & MO & 0 & 0 & 0 & 3180 & 0 & 0 & 0 & 3180 \\
\hline & 80 & 2,940 & 372 & & 1.000 & & 0 & \\
\hline
\end{tabular}

\begin{tabular}{cccccccccc}
1 & Lor & 0 & 0 & 0 & 74200 & 0 & 0 & 0 & 74200 \\
1 Lor & 0 & 0 & 0 & 99640 & 0 & 0 & 0 & 99640 \\
\hline & 0 & 0 & 0 & 173,840 & 0 & 0 & 0 & 173,840
\end{tabular}

$48,319{ }_{1,937,022^{229,765}}{ }_{1.677,178^{1,211,072}}^{4,675,561} 169,948$

$9,900,546$ 